University of Montana

ScholarWorks at University of Montana

1999

\title{
Habitat Relationships of Landbirds in the Northern Region, USDA Forest Service
}

Richard L. Hutto

University of Montana - Missoula, hutto@mso.umt.edu

Jock S. Young

University of Montana - Missoula

Follow this and additional works at: https://scholarworks.umt.edu/biosci_pubs

Part of the Biology Commons

Let us know how access to this document benefits you.

\section{Recommended Citation}

Hutto, Richard L.; Young, Jock S. 1999. Habitat relationships of landbirds in the Northern Region, USDA Forest Service. Gen. Tech. Rep. RMRS-GTR-32. Ogden, UT: U.S. Department of Agriculture, Forest Service, Rocky Mountain Research Station. 72 p.

This Report is brought to you for free and open access by the Biological Sciences at ScholarWorks at University of Montana. It has been accepted for inclusion in Biological Sciences Faculty Publications by an authorized administrator of ScholarWorks at University of Montana. For more information, please contact scholarworks@mso.umt.edu. 
United States

Department

of Agriculture

Forest Service

Rocky Mountain

Research Station

General Technical

Report RMRS-GTR-32

July 1999

Habitat Relationships of Landbirds in the Northern Region, USDA Forest Service

进空

Richard L. Hutto Jock S. Young

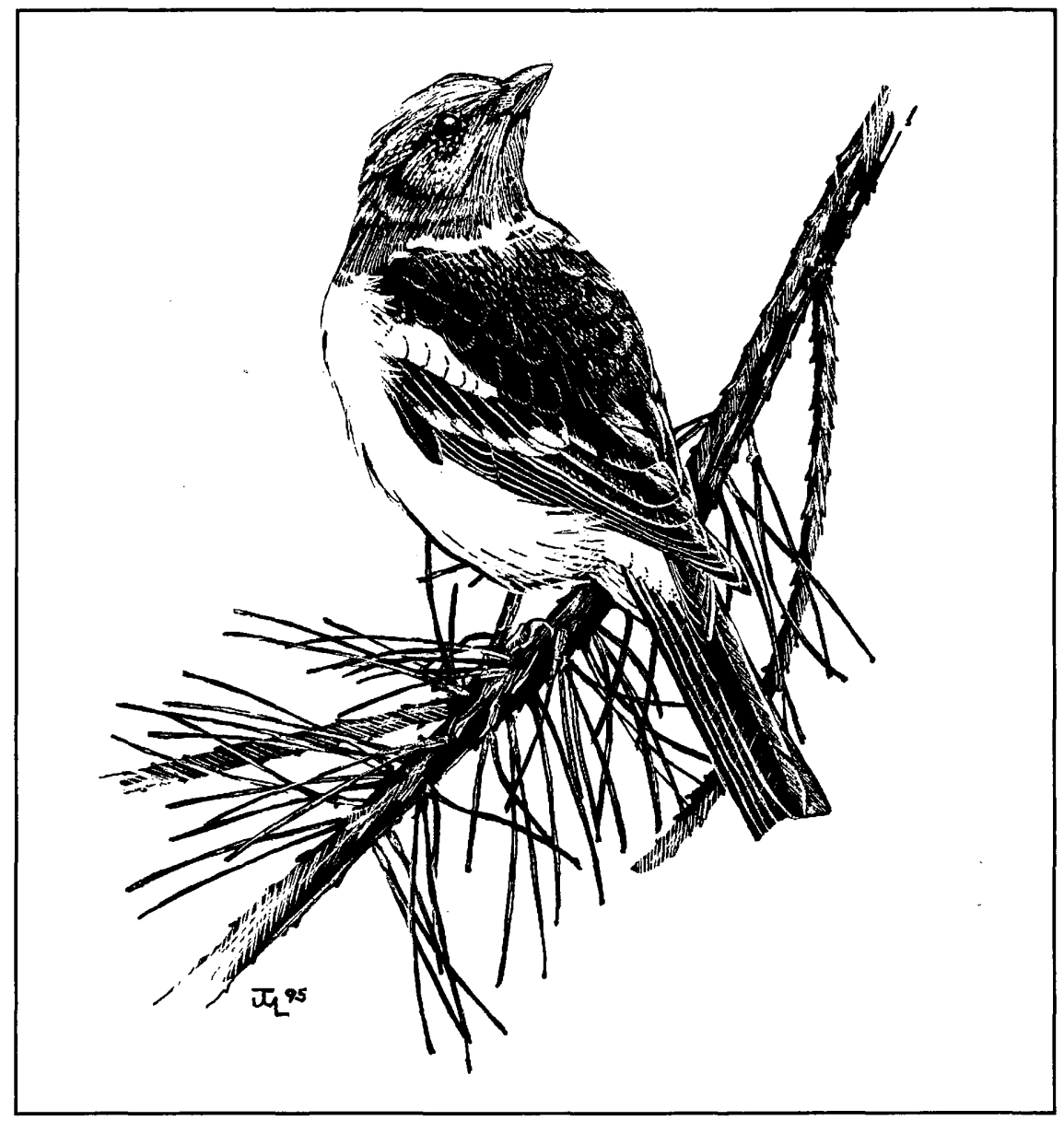




\section{Abstract}

Hutto, Richard L.; Young, Jock S. 1999. Habitat relationships of landbirds in the Northern Region, USDA Forest Service. Gen. Tech. Rep. RMRS-GTR-32. Ogden, UT: U.S. Department of Agriculture, Forest Service, Rocky Mountain Research Station. 72 p.

A series of first-generation habitat-relationships models for 83 bird species were detected in a 3-year study on point counts conducted in association with the USDA Forest Service's Northern Region Landbird Monitoring Program. The models depict probabilities of detection for each of the bird species on 100-m-radius, 10-minute point counts conducted across a series of major vegetation cover types. Based on these models, some bird species appear to be restricted in their habitat distribution to: (1) postfire, standing-dead forests, (2) relatively uncut, older forests, (3) harvested forest types, (4) marshes, (5) riparian environments, and (6) grasslands and sagebrush. Such restricted distributions highlight the need to provide adequate amounts of these cover types to maintain viable species populations. Many bird species were relatively abundant in harvested forests, suggesting a need for nesting success studies because timber harvesting creates unnatural cover types that may elicit settling responses by species that are "programmed" to respond to similar naturally occurring cover types. Thus, these unnatural cover types could be acting as "ecological traps," where species are being attracted to sites where suitability is relatively poor.

These preliminary results demonstrate the utility of a landbird monitoring program, and suggest that agencies such as the Forest Service should consider broadening the indicator species concept to monitor groups of species (such as landbirds and butterflies) that can be easily sampled with a single field method. The list of species covered by this program is indeed large enough and ecologically broad enough to help managers predict and monitor the effects of management activities on almost all the major vegetation types in the region. The detail and region-specific nature of this information can be matched by no other database in existence on landbirds, and the information should prove useful to land managers in planning areas that might consist of alternative cover types.

Keywords: bird-habitat associations, ecological trap, fire effects, indicator species, logging effects, monitoring, Northern Rocky Mountains, point count, riparian

\section{The Authors}

Richard L. Hutto is a Professor of biology and wildlife biology in the Division of Biological Sciences at the University of Montana. He holds a B.A. degree in zoology from the University of California, Los Angeles, an M.S. degree in biology from Northern Arizona University, and a Ph.D. degree in biology from the University of California, Los Angeles. He has been working with the Northern Region of the USDA Forest Service on the development and implementation of a landbird monitoring program since 1990. Phone: 406-243-4292, and e-mail at hutto@selway.umt.edu

Jock S. Young is a Research Assistant in the Division of Biological Sciences at the University of Montana. He holds a B.S. degree in zoology from Oregon State University, an M.A. degree in ecology from the University of California, San Diego, and an M.S. degree in biology from the University of Montana. He has worked on the landbird monitoring program in different capacities since 1993, and as a data analyst since 1996. 


\section{Acknowledgments}

We received financial support for developing the landbird monitoring program from the USDA Forest Service's Northern Region (contract \#53-0343-2-00207), the Bureau of Land Management (PO\# 1422E070P50036), and Plum Creek Timber Company (check \#191090). This support would not have been possible without the efforts of Alan Christensen, Sally Sovey, and Lorin Hicks from each agency, respectively. Indirect and in-kind support was provided by Montana Fish, Wildlife and Parks (thanks to Dan Casey), and Potlatch Corporation (thanks to Bill Wall). Alan Christensen, Skip Kowalski, and Kirk Horn provided the political support necessary to stimulate the growth of this program from an experimental one to one that has become a priority for Montana and the Forest Service. Sallie Hejl, of the Rocky Mountain Research Station, USDA Forest Service, provided detailed consultation and guidance during the design phases of our field studies. The first full-time Northern Region Landbird Monitoring Program Coordinator, Christine Paige, provided the logistic help necessary to hire field crews and then organized and cleaned the data that were submitted by the crews. Chris also provided just the right amount of resistance to proposed methodology so that we could develop the best working protocol to assure success before, during, and after the field season. Forest and District biologists were instrumental in positioning transects and in supervising field crews on their Forests. We are especially grateful to Paul Hendricks and Andrew Bosma for help with data management and analyses, and to Wendy Williams for help preparing graphics for this report. Sallie Hejl, Jared Verner, Kevin McKelvey, and Martin Raphael provided detailed comments on an earlier draft of the manuscript. Finally, we thank all of the field assistants, who, as readers will be able to judge for themselves, did a great job collecting the point-count data; from 1994 to 1996 these were J. Adams, J. Balcomb, L. Ballinger, J. Barilla, L. Bates, D. Bergeron, A. Bosma,
D. Bourdin, D. Casey, A. Cilimburg, C. Couch, F. Curim, C. Cutler, M. DeVries, J. Dodge, K. Duell, R. Fergus, G. Fitzgerald, J. Goodell, G. Grunder, T. Grunder, D. Harvey, P. Heglund, S. Henderson, P. Hendricks, A. Hicks, E. Hill, S. Hitchcox, J. Hoffland, K. Hughes, R. Hutto, A. Jaunakais, K. Johnson, B. Keene, S. Kremer, E. Loomis, D. Martasian, G. Mazer, J. McBride, T. Mears, M. Mercurio, D. Miller, K. Miller, L. Miller, M. Mitchell, J. Moghaddas, B. Pitman, A. Porth, R. Pott, D. Powless, K. Pullen, J. Quinn, D. Reinkensmeyer, P. Reynolds, S. Ritter, J. Ross, J. Slotterback, C. Snetsinger, M. Teesdale, E. Thompson, P. Town, S. Winsor, N. Warren, D. Wirta, and J. Young.

\section{Contents}

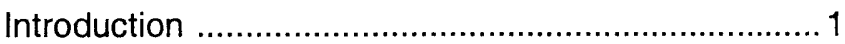

Methods ............................................................... 1

Overall Design ......................................................... 1

Locations of Long-Term Monitoring Points .............. 2

Field Methods ...................................................... 2

Point-Count Methodology ...................................... 2

Vegetation Cover Type Associated with

Each Point ......................................................... 3

Habitat-Relationships Models ...............................

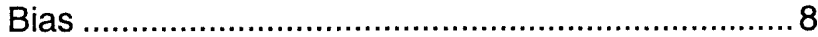

Bird Names ..................................................... 13

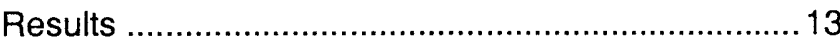

Species Accounts ................................................. 17

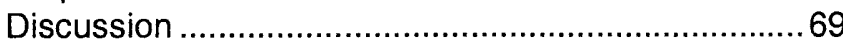

Post-Fire, Standing-Dead Forests .........................69

Relatively Uncut Forests ......................................69

Harvested Forest Types ....................................69

Marshes ........................................................ 70

Riparian Vegetation ............................................ 70

Grassland, Sagebrush, or Both ............................70

Conclusions ......................................................... 70

References ……............................................... 71

You may order additional copies of this publication by sending your mailing information in label form through one of the following media. Please specify the publication title and General Technical Report number.

\section{Ogden Service Center}

Telephone (801) 625-5437

FAX (801) 625-5129, Attn: Publications

E-mail pubs/rmrs_ogden@fs.fed.us

Web site http://www.xmission.com/ rmrs

Mailing Address Publications Distribution

Rocky Mountain Research Station

324 25th Street

Ogden, UT 84401
Fort Collins Service Center

(970) 498-1719

(970) 498-1660

rschneider/rmrs@fs.fed.us

http://www.xmission.com/ -rmrs

Publications Distribution

Rocky Mountain Research Station

3825 E. Mulberry Street

Fort Collins, CO 80524 



\title{
Habitat Relationships of Landbirds in the Northern Region, USDA Forest Service
}

\author{
Richard L. Hutto \\ Jock S. Young
}

\section{Introduction}

In 1993, the Northern Region of the USDA Forest Service initiated a regionwide landbird monitoring program so that managers might better understand the habitat relationships of landbirds that breed in the Northern Rocky Mountains and, in the future, might be able to assess longer-term landbird population trends. The program was initiated to help the Forest Service meet its legal mandate (National Forest Management Act of 1976) to monitor populations of "indicator" species as a mechanism to maintain viable populations of native vertebrates. Landbirds are a good indicator species "survey group" (Hutto 1998) because they are highly visible and many species can be surveyed simultaneously.

Maintaining the integrity of ecosystems will probably involve maintaining major vegetation cover types in "natural" amounts and distributions across a landscape. Therefore, the first step in the landbird monitoring program was to establish an objective and quantitative description of the distributions of bird species across the major vegetation types in the Northern Region. Although published bird field guides contain a rough idea of habitat associations, they do not provide quantitative information on differences in the probabilities of occurrence among vegetation types, especially the vegetation types created through timber harvesting and occupying large extents of landscape. Thus, we established a series of broadly distributed bird survey points throughout the region in an attempt to sample each major vegetation cover type adequately for the models.

This publication (1) describes the overall design and field methods involved with the habitat relationships part of the Northern Region Landbird Monitoring Program, and (2) presents preliminary results of habitat relationships based on field surveys conducted between 1994 and 1996, the initial years of full-scale data collection at permanently marked points.

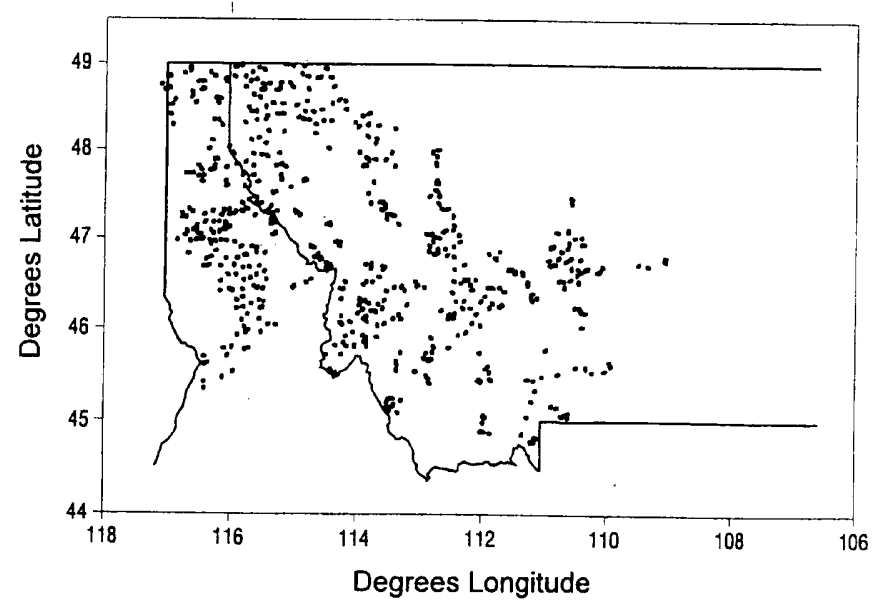

Figure 1-The distribution of permanent landbird monitoring transects in northern Idaho and western Montana.

\section{Methods}

\section{Overall Design}

Sample points were distributed across all $13 \mathrm{Na}$ tional Forests in the Northern Region. Data from the Custer National Forest, however, were confined to the Little Missouri National Grasslands of North Dakota and involved a different assemblage of species in largely nonforested cover types, so these data are not included here. A total of 566 10-point transects were geographically stratified by 7.5 -minute topographic quadrangle maps throughout the nonwilderness lands of the other 12 National Forests (fig. 1) and were permanently marked in the field in 1994 as part of this long-term monitoring effort. Each point was sampled once during each breeding season in three consecutive years (1994 to 1996), with a small number of changes in transect locations between years, as discussed in the results. Plans are to continue sampling about half of these points every 
2 years to provide a long-term database for monitoring. During the breeding season of 1994, we also conducted one-time visits to 761 additional sampling points among 84 transects that were stratified by cover type within a focal Landsat scene (path 41 , row 27), regardless of land ownership. This assured adequate coverage in each major cover type that we wanted to include in the models.

Many variables affect the probability of detecting a bird at any one point in space and time, including a bird's distance from the observer (Emlen 1971), the particular survey year (Hejl and others 1988), the observer (Cyr 1981, O'Connor 1981a, Kavanagh and Recher 1983, Ramsey and Scott 1981), time of day (Grue and others 1981, Robbins 1981a, Shields 1977), time of season (Best 1981, Ralph 1981), and weather (O'Connor and Hicks 1980, Robbins 1981b). Many researchers choose to minimize potential bias associated with data from a given point by conducting multiple counts per point, rotating observers among points, and collecting data across several years. The cost of increasing the accuracy of information from any point, however, is a reduced sample size for each treatment (in this instance, cover type). Given that the goal of a habitat-relationships effort is to provide a reasonable estimate of the relative probability of occurrence across fairly broadly defined vegetation cover types, we felt that the best approach was to maximize the coverage of each type through large sample sizes, at the expense of repeat visits (Ralph and others 1995). Larger sample sizes do not necessarily eliminate such potential biases, however. We do not know the extent to which the pattern of a bird species' distribution across cover types is biased by factors confounding the actual relationship, but we highlight instances where we suspect that the reported distribution might be significantly biased, as discussed later in this report.

\section{Locations of Long-Term Monitoring Points}

The permanently marked, 10-point transects were initially mapped by Forest and District biologists who used the following transect and point placement protocol:

1. They obtained 7.5-minute U.S. Geological Survey topographic quad maps, blue-line quads, or orthophoto maps for the entire target area (a National Forest). A topographic quad map was included in the set if it contained at least 25 percent non-Wilderness Forest Service lands.

2. Four transects were initially mapped in each topographic quad, one in each of four quartersections. Transect start points were located by positioning a random point within each quad quartersection and then finding the nearest point on an unpaved, secondary or tertiary, open or closed road or trail. The remaining nine points constituting a transect were positioned at $300-\mathrm{m}$ intervals in the direction determined by the flip of a coin, but not in the direction that would take the transect out of the quad quarter-section. Where there were curves or switch-backs, points were placed at least $250 \mathrm{~m}$ (straight-line distance) apart.

3. Potential transects were retained only if there was reasonable access, defined as no more than a 1.5-mile hike in (less than 1 hour) from where a vehicle could be parked, and no more than a 1- to 1.5-hour drive from the nearest designated camping site. A single transect was randomly chosen from the potential transects within each topographic quad, and any others were retained as backups in the event that, after a field visit, the selected transect proved to be inaccessible.

The same methods were used to position a series of transects on Potlatch Corporation lands in central Idaho and a small subset of Bureau of Land Management lands in western Montana.

\section{Field Methods}

The order of visits to transects was set by elevation and seasonal access. Relatively low-elevation transects were visited first, and relatively high-elevation sites last. While in the field, an observer marked the location of each permanent survey point with a numbered aluminum tag. The precise location of a point was marked on a color copy of the aerial photo associated with a given transect, and the aerial photo was subsequently used by personnel in the University of Montana Spatial Analysis Laboratory to position those locations onto a Geographic Information System (GIS) data layer. The following information was also entered on the cover page of a field booklet designed to contain all data pertaining to a particular transect in a given year: (1) year, (2) state, (3) name of topographic quad, (4) transect number-unique ninedigit identifier representing the latitude and longitude of the first count point to the nearest minute, (5) USDA Forest Service Region, (6) National Forest, and (7) Forest District.

\section{Point-Count Methodology}

Our field technique followed recommendations discussed by Ralph and others (1995) and methods described by Hutto and others (1986). All observers participated in a joint, 1-week training session and then spent several days in calibration on their respective forests prior to the formal data collection. In general, a 10-minute point count was conducted at each of the 10 sampling points along a transect. 
Points were visited once each breeding season between mid-May and mid-July. All birds seen or heard within the count period were recorded. Field observers generally began counts about 15 minutes after sunrise (after the predawn chorus), which was usually sometime between 0630 and 0700 , and generally completed counts by 1030 or 1100 . Counts were not conducted on days with continuous rain (not light drizzles) or days with wind that was constant and of enough strength to bend the tops of trees (Beaufort 5 , as defined below). At each point, an observer recorded the following information into the field data booklet:

1. The observer's name

2. Date

3. Point number on transect

4. Time-of-day that the count was started

5 . Beaufort wind speed, coded as $0[<1 \mathrm{mph}$, smoke rises vertically], 1 [ 1 to $3 \mathrm{mph}$, wind direction shown by smoke drift], 2 [ 4 to $7 \mathrm{mph}$, wind felt on face, leaves rustle at times], 3 [8 to $12 \mathrm{mph}$, leaves and small twigs in constant motion, light flag extended], 4 [13 to $18 \mathrm{mph}$, raises dust and loose paper, small branches in motion], 5 [19 to $24 \mathrm{mph}$, small trees sway, crested wavelets on inland waters]

6 . Weather condition coded as 0 [clear, or very few clouds], 1 [partly cloudy with sky roughly half obscured], 2 [mostly cloudy with a few sky openings], 3 [fog or smoke that impairs visibility beyond $30 \mathrm{~m}$ ], 4 [light drizzle], 5 [constant snow]

7. Air temperature

8. Four-letter bird species code for each simultaneous detection of one or more individuals from a given distance and direction

9. Number of individuals detected at a given distance and bearing

10. Distance to the bird(s) to the nearest $5 \mathrm{~m}$ inside $50 \mathrm{~m}$, and to nearest $10 \mathrm{~m}$ beyond.

"Spishing" was not allowed during a count, but was a perfectly acceptable way to attract nearby birds after a count to get positive identifications of birds detected before the end of the count.

\section{Vegetation Cover Type Associated with Each Point}

After the 10 point counts had been conducted, observers stopped at each point on the return trip to record additional information associated within a prescribed area surrounding each point. For the purposes of this report, the relevant variable was cover type-a 5-digit code (table 1) representing the vegetation cover type within which the count point was positioned. If the point was precisely on the edge between two or more types, the observer used the type in which the majority of birds were detected.
We considered the Rocky Mountain landscape to consist of a matrix of land units, each relatively homogeneous in vegetation structure and plant species composition, and each differing from adjacent units according to the same criteria. Each sample point, therefore, fell within one of a range of vegetation cover types defined by a combination of the dominant plant species in the tallest vegetation layer and the vertical and horizontal vegetation structure (table 1 ).

The basic cover type framework was one that included vegetation types dominated by one or more plant species. Open lands were usually dominated by grasses or sagebrush (Artemisia spp.). Several riparian cover types were used, including marshes, shrubby riparian areas (with willow [Salix spp.] or miscellaneous shrubs), aspen (Populus tremuloides) stands or cottonwood (Populus trichocarpa) bottomlands.

Because conifer forest stands frequently undergo natural or human-induced disturbance that creates structurally different cover types, we defined our conifer cover types based on three criteria: tree species composition, successional stage, and, for the earlier stages, structure following disturbance (amount of canopy remaining). Tree species composition was categorized as either mixed conifer or as a tree species type if more than 80 percent of the canopy consisted of one (or an associated pair) of conifer species (Douglas-fir [Pseudotsuga menziesii], ponderosa pine [Pinus ponderosa], lodgepole pine [Pinus contorta], western larch [Larix occidentalis], grand fir [Abies grandis], whitebark pine [Pinus albicaulis], limber pine [Pinus flexilis], a combination of western red cedar [Thuja plicata] and western hemlock [Tsuga heterophylla], a combination of Engelmann spruce [Picea engelmannii] and subalpine fir [Abies lasiocarpa]).

We defined seven successional stages: recent disturbance, low shrub, tall shrub, pole/sapling, young, mature, and old growth. For the first four stages we designated a structural type (following disturbance). By the time the stand could be defined as young forest, the original structure following disturbance was considered less important and was usually unknown, so it was no longer designated. Our classification of disturbed forest types was based on the existing plant species composition and stand structure (what the birds respond to) without regard to the process that actually caused the structure. Names associated with structural types (patch cut, shelterwood, seed tree, clearcut) are, therefore, merely descriptive of the process that probably (but not necessarily) gave rise to the current stand condition. We also had a common and diverse partially cut category (including thinning, single-tree selection, overstory removal), which, because of the complexity of the stands, we did not assign to a successional stage. 
Table 1-Northern Rocky Mountain cover type classification scheme.

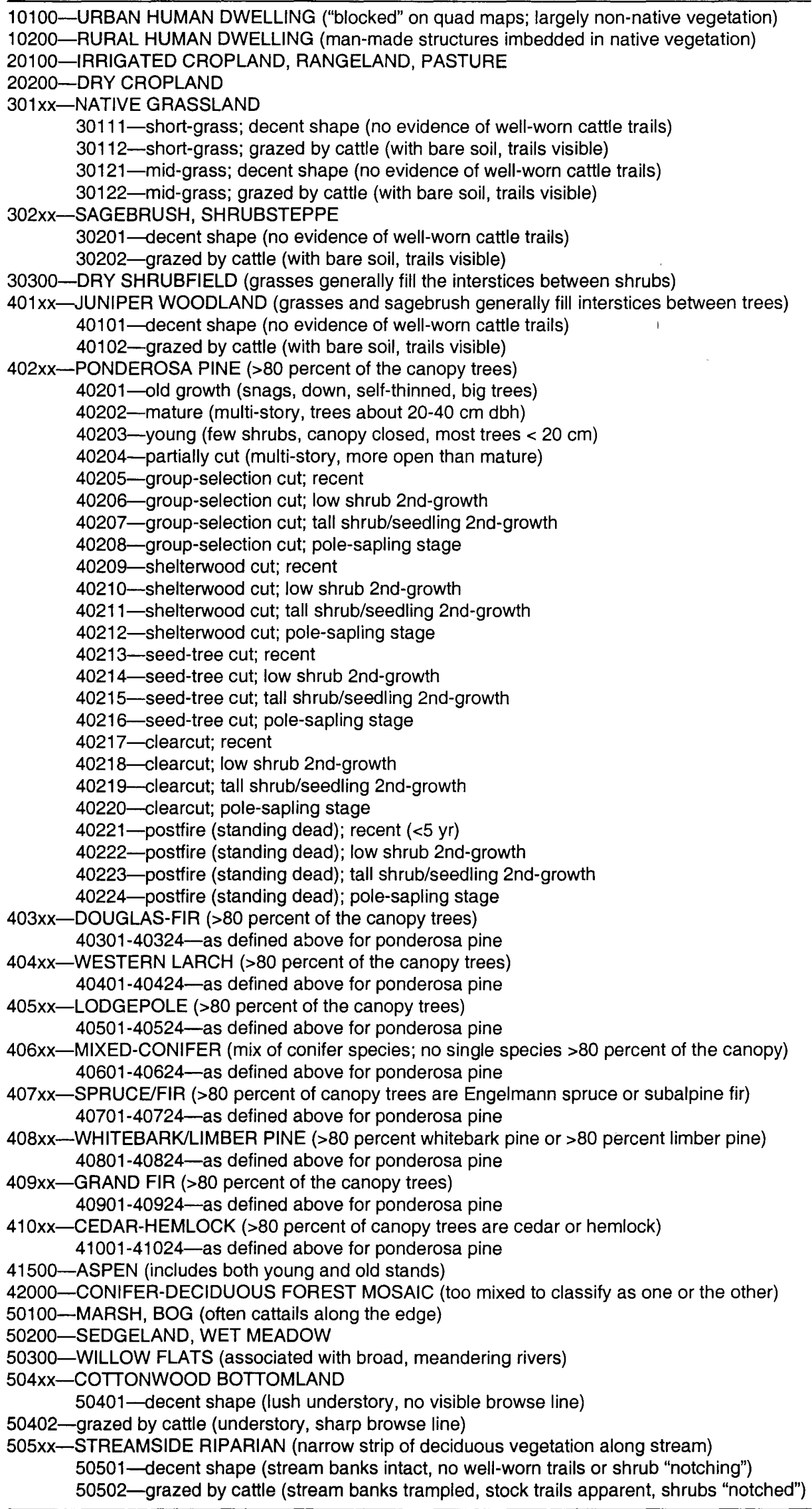


Because our classification scheme resulted in a large number of possible cover types (243; table 1), and many of these ended up with few or no sample points, we combined types to create a smaller series of vegetation types prior to model building (table 2). We combined categories based on our subjective impression of similarity in both vegetation structure and bird composition, aided by exploratory cluster analyses of those cover types with sufficient data. The mature and old growth stages under each forest type were combined into a single undisturbed category for each forest type. These stands showed no significant signs of recent logging activity, although they might have been initiated by logging in the past. This resulted in six types of uncut forest based on species composition (table 2). Data from each of four harvest treatments (Partial Cuts, including thinned, shelterwood, overstory removal; Patch Cuts, including group-selection cuts; Seed-tree Cuts, including other similar harvest units; and Clearcuts) and Post-Fire conditions were combined across conifer forest types, resulting in five "disturbance" categories for conifer forests (table 2). For clearcuts, the pole-sapling stage was retained separately from the earlier three successional stages as "Old Clearcut" because this stage is structurally different from recently cut areas and represents a transitional stage to Young Forest. The three early stages (recent, low shrub, and tall shrub/ seedling) were combined as "Clearcut." Within the other four disturbance categories, we combined all four temporal stages of postharvest development from the "recent" stage to the pole-sapling stage (these stages were never reported for the Partial Cut category). Young, Forest also included all tree species compositions. Data from residential areas, croplands, mixed broadleaf/conifer, dry shrubfield, juniper (Juniperus scopulorum) woodland, tundra, and barren land cover types were insufficient for separate analyses and were eliminated rather than lumped into one of the other cover types because of the relatively distinct vegetation structure associated with each. Larch, whitebark, and limber pine forests were also

Table 2-For each of 18 cover type categories used to depict available habitat in the Northern Rocky Mountains, the table includes the finer resolution cover types included in that category, a category description, and the number of transect points that were used in habitatrelationships in each of the 3 years of the study. Photographs of representative cover types within each of the 18 broader categories are in a companion field methods manual (Hutto and Hoffland 1996).

\begin{tabular}{|c|c|c|c|c|c|}
\hline $\begin{array}{c}\text { Cover type } \\
\text { category }\end{array}$ & \multicolumn{3}{|c|}{ Number of points used } & Cover types included & Description \\
\hline Cedar/Grand Fir & 57 & 40 & 49 & $41001,41002,40901,40902$ & $\begin{array}{l}\text { At least } 80 \text { percent of the canopy cover in this type was } \\
\text { comprised of grand fir or a combination of cedar and } \\
\text { hemlock, and it included mature and old growth stages. }\end{array}$ \\
\hline Spruce/Fir & 53 & 65 & 62 & 40701,40702 & $\begin{array}{l}\text { At least } 80 \text { percent of the canopy cover in this type was } \\
\text { comprised of a combination of spruce and subalpine fir. } \\
\text { The type includes forests in mature and old growth } \\
\text { stages. }\end{array}$ \\
\hline Lodgepole Pine & 84 & 118 & 108 & 40501,40502 & $\begin{array}{l}\text { At least } 80 \text { percent of the canopy cover in this type was } \\
\text { comprised of its namesake, and it included mature and } \\
\text { old growth stages. }\end{array}$ \\
\hline Mixed Conifer & 344 & 522 & 587 & 40601,40602 & $\begin{array}{l}\text { No single conifer species made up more than } 80 \\
\text { percent of the canopy cover in this forest type. This } \\
\text { category included mature and old growth stages. }\end{array}$ \\
\hline Ponderosa Pine & 24 & 20 & 32 & 40201,40202 & $\begin{array}{l}\text { At least } 80 \text { percent of the canopy cover in this type was } \\
\text { comprised of its namesake, and it included mature and } \\
\text { old growth stages. }\end{array}$ \\
\hline Young Forest & 157 & 213 & 144 & $\begin{array}{l}40203,40303,40403,40503 \\
40603,40703,40803,40903 \\
41003\end{array}$ & $\begin{array}{l}\text { This type includes young forest from all of the above } \\
\text { types, regardless of tree species combination. These } \\
\text { were stands with the majority of trees under } 20 \mathrm{~cm} \mathrm{dbh} \text {. } \\
\text { Physiognomically, these were usually closed-canopy } \\
\text { stands with little understory. }\end{array}$ \\
\hline
\end{tabular}


Table 2 (Con.)

\begin{tabular}{|c|c|c|c|c|c|}
\hline \multirow{2}{*}{$\begin{array}{c}\text { Cover type } \\
\text { category }\end{array}$} & \multicolumn{3}{|c|}{ Number of points used } & \multirow[b]{2}{*}{ Cover types included } & \multirow[b]{2}{*}{ Description } \\
\hline & 1994 & 1995 & 1996 & & \\
\hline Partial Cut & 755 & 432 & 416 & $\begin{array}{l}40204,40304,40404,40504 \\
40604,40704,40804,40904 \\
41004 \\
40209-40212,40309-40312 \\
40409-40412,40509-40512 \\
40609-40612,40709-40712 \\
40809-40812,40909-40912 \\
41009-41012\end{array}$ & $\begin{array}{l}\text { This type includes forest stands with a variable amount } \\
\text { of mature canopy trees removed, from minor thinning } \\
\text { to major overstory removal. It includes shelterwood } \\
\text { cuts, in which uniformly spaced, large trees were left } \\
\text { to provide shade for regenerating seedlings. }\end{array}$ \\
\hline Patch Cut & 73 & 43 & 43 & $\begin{array}{l}40205-40208,40305-40308 \\
40405-40408,40505-40508 \\
40605-40608,40705-40708 \\
40805-40808,40905-40908 \\
41005-41008\end{array}$ & $\begin{array}{l}\text { This type includes forest stands wherein clusters } \\
\text { of trees were removed, leaving the appearance of } \\
\text { clusters of trees with large open spaces in between. } \\
\text { Physiognomically, this type includes stands in the } \\
\text { earliest postharvest successional stage (with shrub and } \\
\text { seedling development still below } 1 \mathrm{~m} \text { in height) up to } \\
\text { the pole-sapling stage (with trees up to about } 10 \text {-cm } \\
\text { dbh). A relatively small proportion (less than } 5 \text { percent) } \\
\text { of this type consisted of what were fairly pure stands of } \\
\text { one of the conifer species designated above; most of } \\
\text { the pretreatment stands were mixed-conifer. }\end{array}$ \\
\hline Seed-tree cut & 68 & 51 & 34 & $\begin{array}{l}40213-40216,40313-40316 \\
40413-40416,40513-40516 \\
40613-40616,40713-40716 \\
40813-40816,40913-40916 \\
41013-41016\end{array}$ & $\begin{array}{l}\text { This type includes forest stands wherein most trees } \\
\text { were removed and a few widely spaced (generally } \\
\text { fairly mature) trees were left. All stands with these } \\
\text { general features were included regardless of what } \\
\text { the silvicultural prescription may have been. }\end{array}$ \\
\hline Clearcut & 100 & 95 & 76 & $\begin{array}{l}40217-40219,40317-40319 \\
40417-40419,40517-40519 \\
40617-40619,40717-40719 \\
40817-40819,40917-40919 \\
41017-41019\end{array}$ & $\begin{array}{l}\text { This type includes forest stands within which nearly } \\
\text { all trees have been removed; only a few snags or a } \\
\text { smattering of (generally small) trees remain. This type } \\
\text { is similar to the postfire category except that there are } \\
\text { numerous standing dead trees in the "natural" postfire } \\
\text { situation. Succesional stages from recent to tall shrub } \\
\text { stages are included here. }\end{array}$ \\
\hline Old Clearcut & 175 & 90 & 76 & $\begin{array}{l}40220,40320,40420,40520 \\
40620,40720,40820,40920 \\
41020\end{array}$ & $\begin{array}{l}\text { This type includes forest stands within which nearly all } \\
\text { trees were removed, as above; only the more advanced } \\
\text { sucessional stage is included here, generally consisting } \\
\text { of a pole-sapling conifer stand. }\end{array}$ \\
\hline Post-Fire & 44 & 37 & 46 & $\begin{array}{l}40221-40224,40321-40324 \\
40421-40424,40521-40524 \\
40621-40624,40721-40724 \\
40821-40824,40921-40924 \\
41021-41024\end{array}$ & $\begin{array}{l}\text { This type consisted of forest stands that had experienced } \\
\text { a relatively intense stand-replacement crown fire, as } \\
\text { evidenced by the presence of numerous blackened, } \\
\text { standing-dead trees. }\end{array}$ \\
\hline Sagebrush & 79 & 84 & 61 & 30201,30202 & $\begin{array}{l}\text { This type is dominated by its namesake, although } \\
\text { native grasses and junipers may have been present. } \\
\text { It includes both heavily grazed and relatively ungrazed } \\
\text { subgroups. }\end{array}$ \\
\hline Grassland & 111 & 74 & 57 & $30111,30112,30121,30122$ & This type includes short- and mid-grass prairies. \\
\hline Wetland & 24 & 57 & 34 & 50100,50200 & $\begin{array}{l}\text { This riparian type includes areas with standing water } \\
\text { that supported either short-statured marsh or meadow } \\
\text { vegetation. }\end{array}$ \\
\hline Riparian Shrub & 212 & 344 & 252 & $50300,50501,50502$ & $\begin{array}{l}\text { This type includes areas that have a well developed } \\
\text { riparian vegetation component dominated by shrubs } \\
\text { (for example, alder, maple, willow). }\end{array}$ \\
\hline Cottonwood/Aspen & 57 & 83 & 48 & $41500,50401,50402$ & $\begin{array}{l}\text { This riparian type includes aspen stands of all kinds, } \\
\text { and streamside areas that generally contain an } \\
\text { abundant cottonwood canopy cover. }\end{array}$ \\
\hline
\end{tabular}


excluded due to low sample sizes. Grand fir forests were combined with cedar-hemlock, because birds probably respond to these similarly, and each was sampled insufficiently when considered alone. Aspen was also combined with Cottonwood for the same reasons. Bird species that responded differently to these two types are noted. The final categorization resulted in 18 cover types (table 2 ).

\section{Habitat-Relationships Models}

We present habitat distributions as the observed percentage of points within each cover type at which a given species was detected. The histogram bars for each species show the mean and standard deviation of the observed percentages across the 3 years of data within each cover type. The error bars should not be used as a statistical test of differences among cover types because they involved only 3 years, they were not strictly independent samples, and they do not reflect the differing sample sizes (and thus the variable accuracy) associated with each cover type. Error bars were included only as indications of the consistency of the results across years.

For nonriparian cover types, we excluded points that were positioned within $100 \mathrm{~m}$ of the edge of another cover type to reduce the chance that birds would have been detected within a cover type that differed from that recorded at the census point. For each of the three riparian types (Wetland, Riparian Shrub, and Cottonwood/Aspen), however, we had to include all points, whether or not another cover type was within $100 \mathrm{~m}$, because most riparian patches are small or narrow and, therefore, virtually all points were located within $100 \mathrm{~m}$ of another cover type. Thus, the number of points used to calculate the probabilities of occurrence across cover types was substantially less than the number actually conducted in the field (about 40 percent, including removal of minor cover types). In addition, we used only bird detections that occurred within $100 \mathrm{~m}$ of the observer, to exclude birds that may have been in another, unknown cover type beyond this observation limit. Thus, the resultant probabilities of detection are associated with relatively homogeneous patches of each cover type. The fixed radius also increased the chance that a difference in the probability of occurrence between two cover types was the result of a difference in the abundance of a species and not a difference in its detectability within different vegetation types (Hutto and others 1986).

For most species, individuals detected flying over the site were excluded. However, species that forage or display aerially, such as swifts, swallows, Common Snipe (see table 3 for scientific names of all bird species observed), and Common Nighthawk, were frequently detected as flyovers and were generally "using" the airspace within $100 \mathrm{~m}$ of the observer when detected. Therefore, for those species, we included flyover data with the fixed-radius data before building habitat models.

We used individual points as sample units for calculating the percentage detected on a 10-minute point count in a given cover type. Unfortunately, because sample points occurred across the landscape in clusters of 10 (per transect), multiple samples of a given cover type within a single transect were not statistically independent estimates of bird composition within that cover type. Nevertheless, we used individual points as sample units because (1) combining data from all points on a transect would create meaningless sample units with respect to cover type, given that transects themselves run through a series of different cover types; (2) given a mixture of cover types on each transect, and the elimination of points near edges, we included, on average, only 2.3 points per transect from any single cover type; and (3) we are not drawing conclusions based on statistical evaluation of the differences among cover types.

Unfortunately, it is difficult to know the minimum number of detections needed to generate a meaningful model, although the bird species that were detected on only a few points were certainly not detected frequently enough to justify plotting the distribution of occurrences among cover types. Because model reliability undoubtedly increases with number of detections, but the shape of the relationship between accuracy and sample size is unknown, the minimum number of detections needed becomes a subjective decision. One guideline may be the sample size recommended for a chi-square contingency table. To achieve expected values of at least five for all 18 cover types would require 90 individuals. There were 28 species that were detected on at least 90 points in each year. Because we were not actually conducting statistical tests, however, we felt that species with fewer individuals still provided sufficient data to produce meaningful graphical models. We chose to present patterns of distribution for species that were detected within $100 \mathrm{~m}$ on at least 25 points in each of the 3 years. In addition, for 29 less frequently detected species, we included graphs that were based on a pooling of data from all 3 years. These species had more than 30 detections over the total period, and their graphs can be readily distinguished from the data-rich graphs because they consist of open histograms that lack error bars. These graphs may not be as reliable an indicator of habitat distribution due to the small sample size and the nonindependence of points from several years, but the resulting patterns of occurrence for some of the rarer species were instructive to look at and may serve to stimulate further research. 
In figures 8 to 101, the vegetation cover types are listed from the moister to the drier "uncut" conifer types, followed by the harvested conifer forest, nonforest, and riparian types. The harvested forest types are listed in order of increasing amount of timber removed (although the Partial Cut category is variable and the Patch Cuts were, by definition, heterogeneous). It may be noted that Old Clearcuts may be structurally more similar to Young Forest than to the more recent Clearcuts next to which they were placed on the graphs. Patterns of habitat use for a species were made as clear as possible by scaling the percent occurrence relative to the longest bar (cover type within which the species was detected most frequently). Unfortunately, this does not facilitate across-species comparisons of abundance because the longest bars of a common species represent a much higher detection percentage than those of a rarer species. Such comparisons of abundance are inappropriate in any event because the point-count data have not been adjusted for differences in baseline detectability among species.

\section{Bias}

The reported models show the observed percentages of detection for all species. Any assumption that these may be used to predict future occurrence in the various cover types depends on our having an unbiased representation of true habitat distributions. As discussed earlier, many variables are known to affect the probability of detecting a bird at any one point in space and time, including the bird's distance from the observer, the particular year, the observer, time of day, time of season, weather, and so forth. Our large sample size over a wide region helps to average out many of these sources of variation. However, any variable affecting the birds that also differs consistently among cover types may confound our results for observed bird distributions across those types. Because we collected data on many of these potential sources of bias, we examine their possible effects on our results and discuss each source of bias briefly.

Yearly Variation-We present the data for the more frequently detected species (some of fig. 8 to 101) as means of all 3 years with a standard deviation. This will help to average out year-to-year changes in habitat distribution and avoid possible bias associated with results from any one year. While it is unlikely that a bird species will shift between structurally different cover types between years, it is quite possible that the pattern of use of the relatively similar forest types may differ from one year to the next, and the error bars will reflect such variation. The error bars are, of course, a reflection of all sources of sampling error, including yearly variation in cover type occupancy.
Other data on patterns of cover type use suggest that the relative abundance of a species among cover types is similar from one year to the next, even though the absolute abundance in any one cover type may change markedly from year to year (for example, O'Connor 1981b). Such a pattern would result in large error bars, even though the relative differences among cover types might be consistent from year to year. Thus, the error bars must be viewed with some caution, but should, nevertheless, provide an indication of the consistency of our results.

Geographic Distribution-Habitat distribution models may be biased by the inclusion of points outside the geographic range of the species because of the inclusion of suitable habitat that is geographically unavailable to the birds. The Continental Divide represents a climatic and biogeographic boundary within our region, with drier and more open vegetation cover types on the eastside. About 32 percent of the points were east of the Divide, but these included 76 percent of the Grassland and Sagebrush cover, 58 percent of the riparian areas, 63 percent of the Lodgepole Pine, 46 percent of the Douglas-fir, and 42 percent of the Ponderosa Pine, but no Cedar/Grand Fir and only 15 percent of the harvested forest stands, 17 percent of the Spruce/fir, and 18 percent of the Mixed Conifer. Many bird species also had different probabilities of detection on either side of the Divide, and most of these differences were probably due to differences in the occurrence of their respective habitats on either side of the Divide. However, of 46 species that were regularly detected west of the Divide (on more than 2 percent of the points), 12 species were so rare east of the Divide ( 0 to 21 records) that they may be considered limited in geographic range to west of the Continental Divide. Inclusion of data from the eastside in habitat models may give misleading results for these species. To determine if this would change any conclusions about relative habitat distributions, we created new habitat distribution graphs for these species (Pileated Woodpecker, Steller's Jay, Blackcapped Chickadee, Chestnut-backed Chickadee, Brown Creeper, Winter Wren, Varied Thrush, Nashville Warbler, Wilson's Warbler, Black-headed Grosbeak, Fox Sparrow, and Evening Grosbeak), which included only the data from west of the Continental Divide. We present this alternative graph in addition to the original if the differences were noteworthy.

In addition, several common species were several times more likely to be detected in the westside than in the eastside, but because these species did occur in the eastside at low levels, the difference may have been due to habitat rather than geographic range limitations. However, the Townsend's Warbler appears to have a fairly clear range restriction (Montana Bird Distribution Committee 1996), so this species 
was treated as above. Restricting data to the westside meant that several cover types were represented by less than 10 to 20 points in some years, so we pooled the data from all 3 years to construct these graphs. Inspection showed all resulting patterns to be the same as would result from showing the means and (standard deviations) of the 3 separate years.

Time of Season-Although we restricted our data collection to the period of the breeding season during which most bird species were actively singing, many species showed variation in singing intensity during this period. Thus, detection probabilities for many species apparently changed as the breeding season progressed. For example, we detected many species less often in the first week or the final 2 to 3 weeks of our sampling period. Some species reduced their singing even earlier, and a few strongly increased their singing through the season. The habitat distribution graphs for these species may have been biased if there were cover types that were sampled more (or less) frequently during the period of peak singing than during the period of relatively infrequent singing.

Overall, the various cover types were well sampled throughout the season (fig. 2), but a close inspection of histograms showed that there may still be some potential biases associated with a few cover types that were sampled relatively unevenly across the season. This is especially true for high-elevation cover types such as Spruce/Fir (fig. 3a) and Lodgepole Pine. More accessible cover types, such as Ponderosa Pine

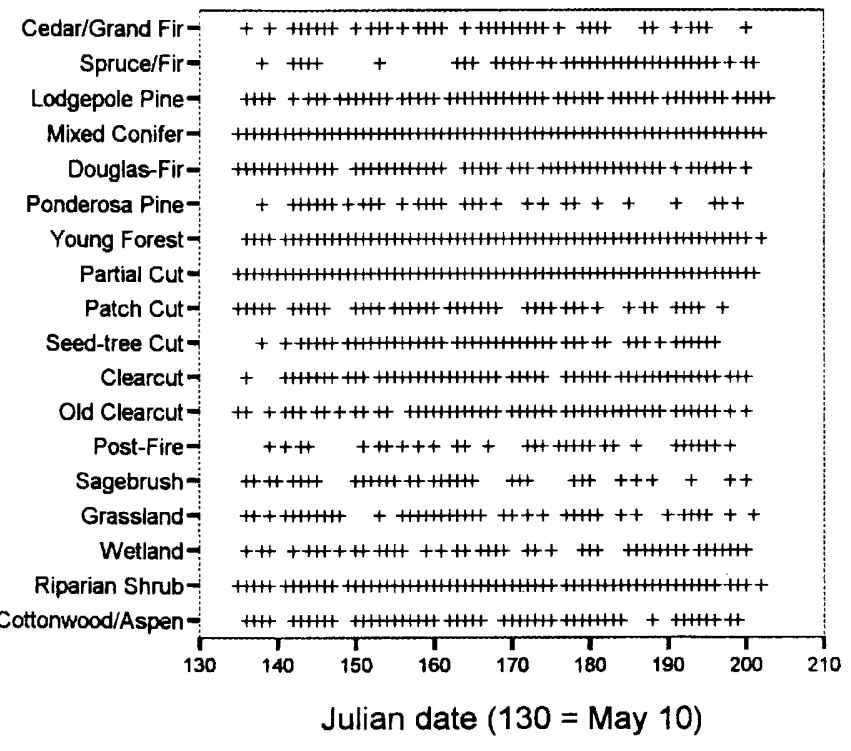

Figure 2-Sampling effort of point counts across season by cover type. Plus signs may represent multiple points. Note the limited sampling of Spruce/ Fir early in the season.

\section{a. Spruce/Fir}

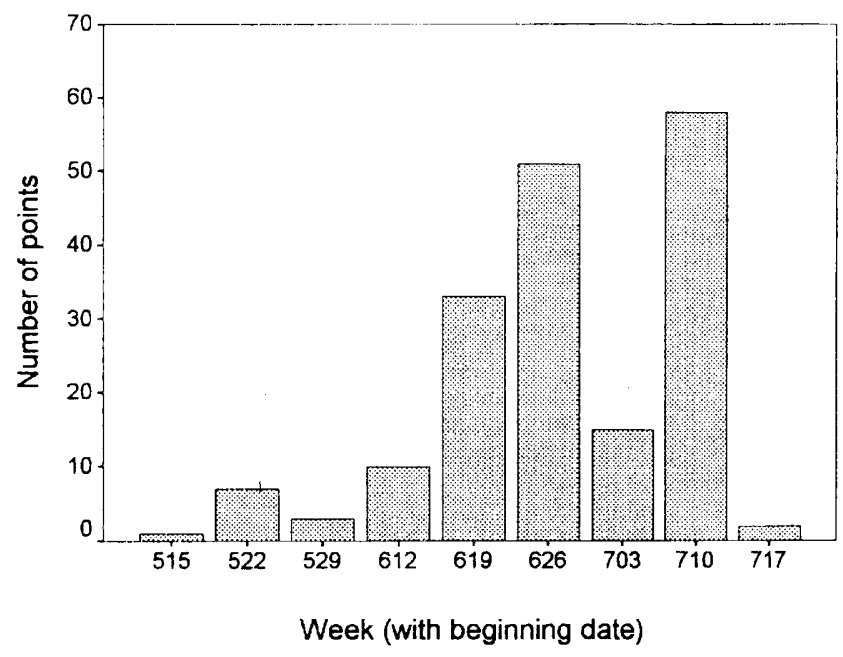

b. Ponderosa Pine

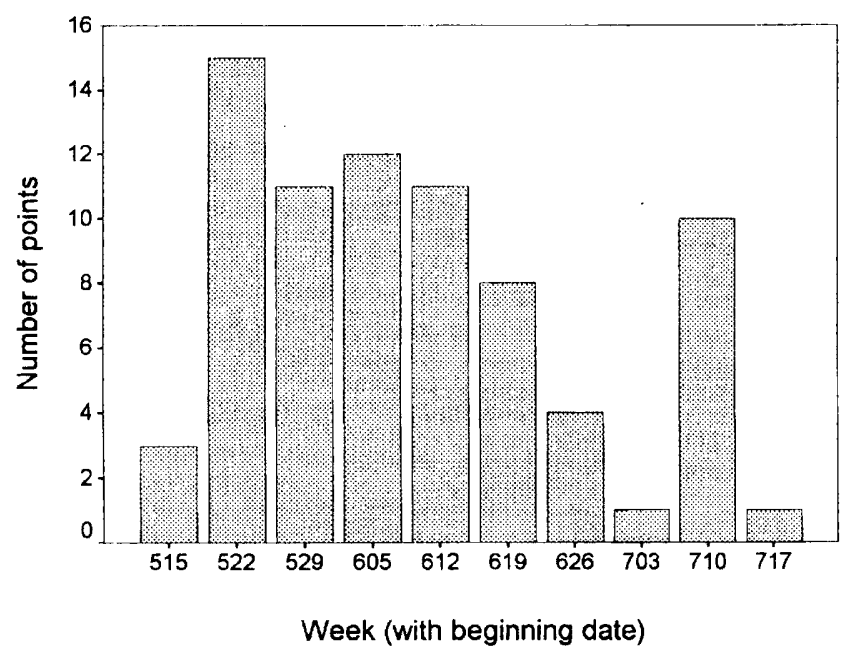

Figure 3-Sampling effort of point counts across season within (a) Spruce/Fir, sampled mostly late in the season, and (b) Ponderosa Pine, sampled mostly early in the season.

(fig. 3b), Sagebrush, and Riparian Shrub, were sampled more frequently in the early part of the season. Therefore, for a bird species that sang more later in the season, such as the Swainson's Thrush (fig. 4), our results may have shown artificially low probabilities of detection in earlier sampled cover types, because many of the points in those cover types were not sampled in the period during which the species was most detectable. Likewise, bird species with declining detection rates through the season, such as Brownheaded Cowbird (fig. 5a) or, in the most extreme case, Ruffed Grouse (fig. 5b), may not be accurately represented in the samples of higher elevation cover types sampled later in the season. Therefore, for those bird 


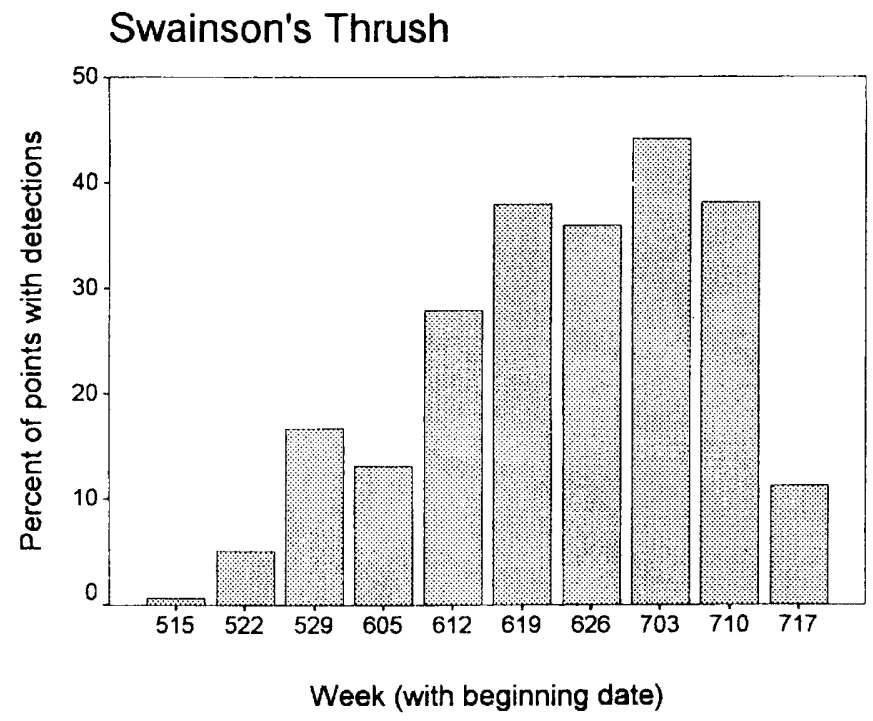

Figure 4-Percent of 10-minute point counts with at least one detection of the Swainson's Thrush, by week ( 3 years combined) across the season.

species that showed marked seasonal shifts in detectability, we constructed an alternative cover type bar chart from a more restricted period of the breeding season during which the species was consistently common.

Specifically, for each of the 19 species for which 80 percent of the detections occurred by June 28, we included data from dates that covered the first 80 percent of the data ( 80 percent of the total points were not completed until July 5). Likewise, for the six species with the most dramatic increase in detection rates ( 80 percent of detections after June 6 ), we included data from dates covering the last 80 percent of the detections. Because of reduced sample sizes, we pooled the data from all 3 years to construct these graphs. A comparison of the two alternative bar charts was used to search for potential biases in the pattern of cover type use based on the entire data set. We present the alternative graph in addition to the original if the differences were noteworthy.

Detectability - The pattern of distribution among cover types for a given species may be biased by detectability differences among cover types of different vegetation structure (Verner 1985). This will be especially true if unlimited-distance survey methods are used, or if there is an attempt to estimate density based on detection distances. One of the main advantages of the fixed-radius point count method that we used is the elimination of long-distance detections that would be especially subject to detectability bias among cover types (Hutto and others 1986). Many authors, in fact, suggest using data taken from a maximum distance of $50 \mathrm{~m}$ (Ralph and others 1995,

\section{a. Brown-headed Cowbird}

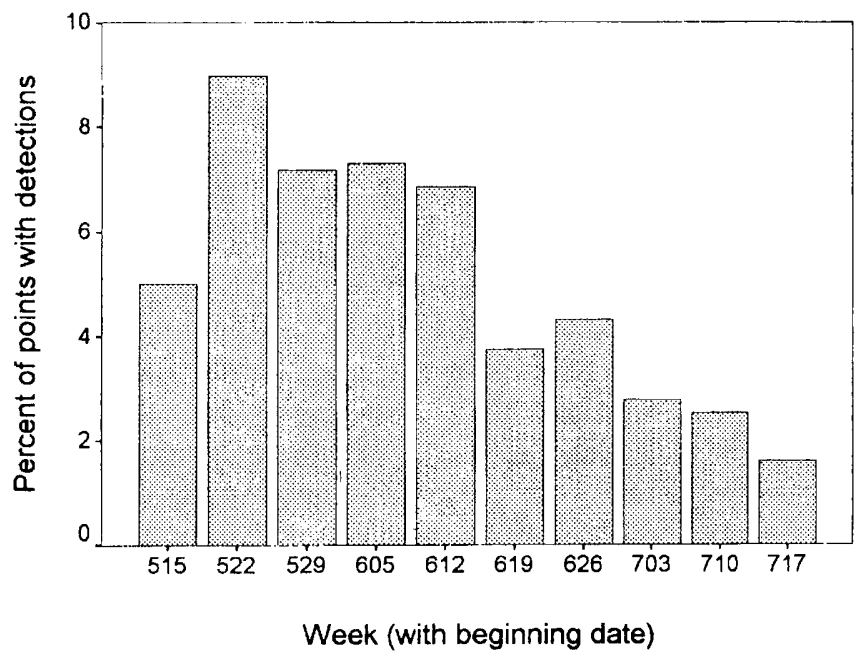

\section{b. Ruffed Grouse}

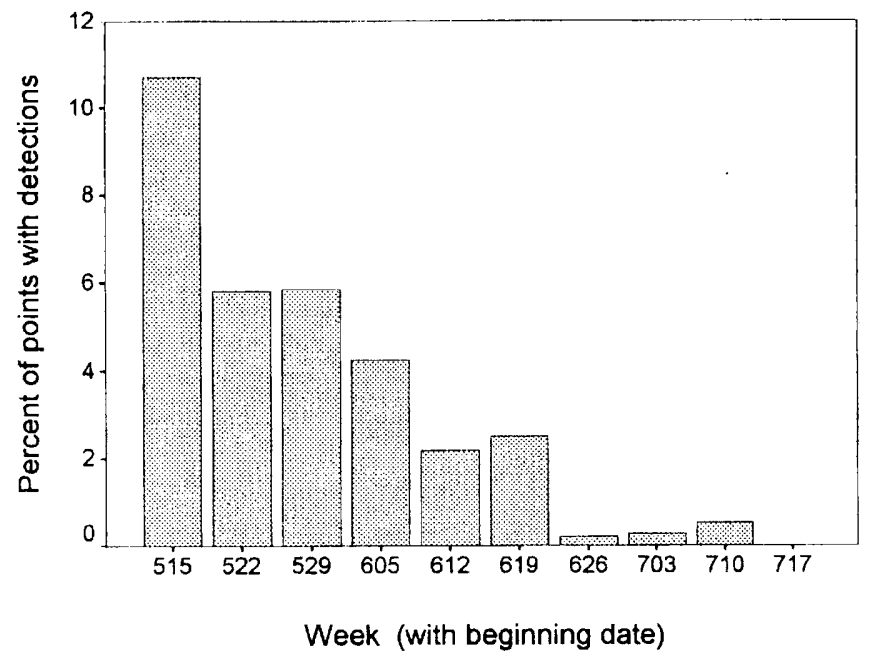

Figure 5-Percent of 10-minute point counts with at least one detection of the (a) Brownheaded Cowbird, and (b) Ruffed Grouse, by week ( 3 years combined) across the season.

Verner 1985). However, our results showed that using this distance as a maximum would result in an average of only five bird detections (of 3.5 species) per point count. Increasing the distance to $100 \mathrm{~m}$ allowed us to use an average of nine bird detections (of 6.1 species) per point in our analyses.

Bias in detectability among cover types is likely to be due to a decreased probability of detection in denser vegetation. Indeed, the mean distance to observed birds differed significantly among cover types (fig. 6), with the mean detection distance being highest in Grassland and Sagebrush areas and lowest in the forested cover types. Within forest types, however, results were unexpected, with the highest detection 


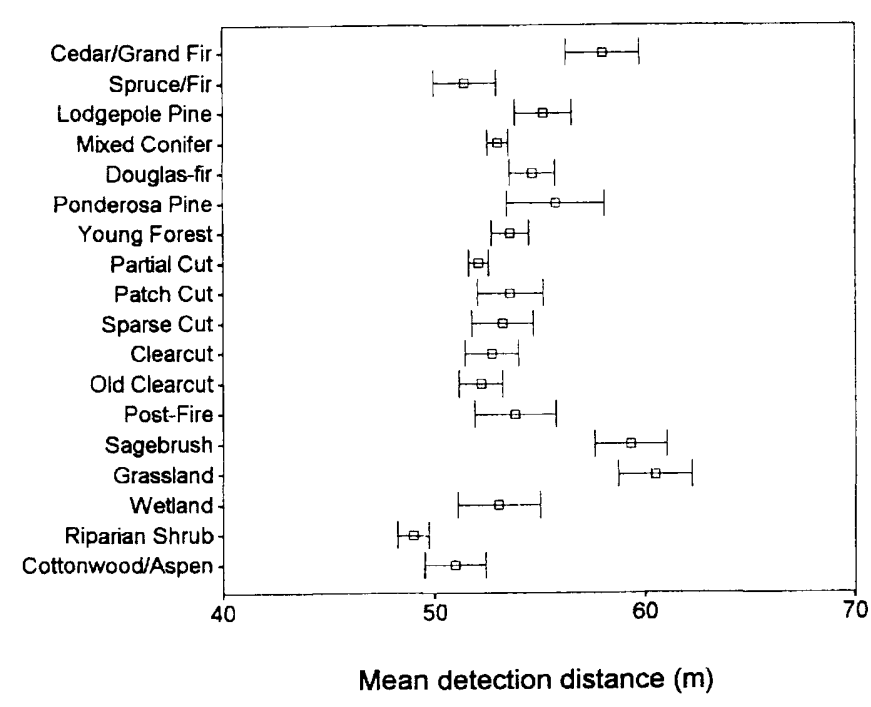

Figure 6-Mean distance (with 95 percent confidence interval) to individuals of the 30 most common species (combined) within each cover type.

distances in Cedar/Grand Fir, which was the cover type with the densest vegetation (highest average canopy cover; fig. 7). This result may have been due to errors in distance estimation. If a detected bird song sounded quieter than one heard in another cover type, the observer may well have estimated a greater distance to the bird, even if the actual cause of the lower volume was the denser vegetation rather than the distance. The end result would be similar: fewer birds would be recorded as being within $100 \mathrm{~m}$ in dense vegetation relative to open. However, we cannot quantify this bias because the only measure we have (estimated distance) is itself biased by the same differences between cover types.

If we cannot quantify the bias, we at least know what to expect; our analyses should be conservative in claiming species to be relatively abundant in dense versus open stands, but may be too liberal in finding the reverse. Fortunately, the former are more likely to be the species of most concern because management practices are more likely to convert dense forest to open rather than vice versa (with the possible exception of dense young stands). It is also of interest that two of the species most difficult to detect at greater distances (Golden-crowned Kinglet and Brown Creeper) can still be shown by our methods to be more abundant in dense forests.

Old Growth-Another source of bias may be the nonuniform inclusion of important habitat elements among cover types. For example, since old growth and mature forests are lumped together in each of the uncut forest cover types, a species that actually prefers old growth may be more frequently detected in a cover type such as Cedar/Grand Fir (which happens to have a relatively large proportion of its points in old growth). To examine whether a bird species' distribution among cover types was biased by the nonuniform coverage of old growth among cover types, we determined which species were more frequently detected in old growth compared with mature forests (regardless of cover type), and we then examined the distribution of these species among uncut forest types for each successional stage. These distributions were compared with that produced by the overall data set to check for any apparent differences. We present the alternative graph in addition to the original if the differences were noteworthy.

Roadside Counts-The reliance on roads or easily accessed trails for our transect locations resulted in some geographic biases (fig. 1). Roadless areas, especially wilderness, were not sampled, except at the edges by transects anchored at trailheads. This greatly reduced sampling in high-elevation vegetation types and remote landscapes. However, most cover types were adequately sampled (table 2 ). The question remains, however, whether data from those cover types were biased by the physical presence of roads.

If bird species abundance data collected at points on roads differs from that which would have been collected at points in the interior of stands, then placement of most transects along roads would give rise to two issues of potential concern: (1) that some bird

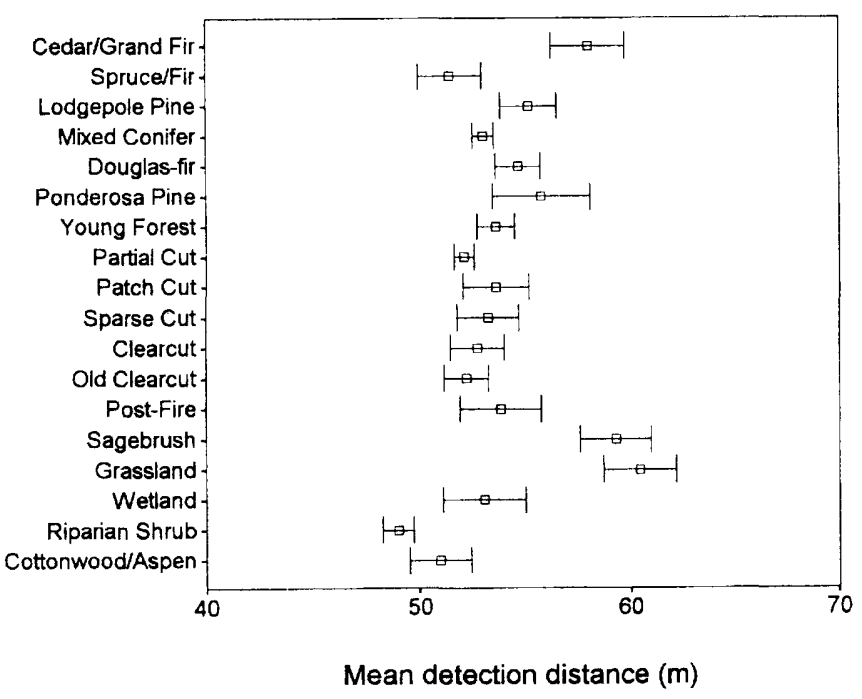

Figure 7-Mean canopy cover (percent) within each cover type. Canopy cover was estimated within $30 \mathrm{~m}$ of the bird count point by the field observer following the bird surveys. 
species may use particular cover types only because of the presence of the road, and (2) that the proportion of on- and off-road points differs among cover types such that a roadside effect might produce a biased picture of habitat use.

Most transects were on tertiary logging roads, and many were closed to motorized vehicles, so disturbance from traffic was not likely to be an issue. Nevertheless, even tertiary logging roads often resulted in wide gaps in the tree canopy, as well as roadside shrubs and saplings due to increased light and runoff water. These habitat modifications may result in changes in bird use. However, our sampling of a 100 $\mathrm{m}$-radius circle assured that we were including a large area unmodified by the road. The use of presence/ absence data may have also helped mitigate the quantitative effect of roads.

Hutto and others (1995) studied the difference between on-road and adjacent off-road point counts in Montana as part of this Landbird Monitoring Program. They found that almost all species were readily detected at on-road points, with no species significantly more abundant at the off-road points, but seven species were significantly more abundant at on-road points. Habitat modification from roads seemed to bring bird species normally associated with open forest (such as Chipping Sparrow and American Robin) and shrubby vegetation (such as Warbling Vireo, MacGillivray's Warbler and Wilson's Warbler) into areas of closed forest canopy. Similar results were found by Keller and Fuller (1995) in Virginia, and Hanowski and Niemi (1995) in Minnesota.

This study was not designed to test the effects of roads on bird detections. The vast majority of our points were along roads. Roadside and trailside points were not paired, and trails may have been in different landscapes, cover types, and elevations relative to roads. Also, trails may still involve some habitat modification. Therefore, we cannot analyze the potential effects of roads using our data. It is clear, however, that most logged stands were near roads, whereas trails were much more likely to be in undisturbed cover types such as uncut conifer forest. Thus, it may not always be possible to separate the effects of roads per se from differences in cover type use.

The use of roadside counts may bias our habitat models to some extent. Species of dense forest may have been detected less frequently than they would have at off-road points, but the relative abundance among cover types is not likely to have been altered, unless they avoid roads to differing degrees in different habitats. On the other hand, species such as the Black-capped Chickadee or Warbling Vireo may be drawn by roadside vegetation to forest cover types where they might otherwise not occur. However, the preference of most of these species for logged or riparian vegetation was still obvious from our graphs. Managers must be aware of the potential effects of roads in our models, especially for species more or less abundant in the more heavily roaded cover types (such as logged forests).

Observer Bias-A large sampling program such as this requires numerous observers to complete. Although all observers participated in an intensive, week-long training session, their abilities and motivation in the various aspects of data collection certainly varied. Dramatic differences have been shown in the ability to detect birds among observers (Cyr 1981, Kavanagh and Recher 1983, Smith 1984, Verner 1985). We expect that observers also differed in their ability to identify bird species, estimate distances, and categorize cover types.

We cannot quantify these differences because we did not have multiple observers visiting the same points simultaneously (except for a few informal tests during the training sessions). We have assumed that the diversity of observers would spread the variability among cover types and regions so that there were no systematic biases. Systematic biases were most likely to occur where multiple observers were prone to the same errors. Such errors were especially likely in the identification of bird species pairs that are difficult to distinguish. Dusky and Hammond's Flycatchers were the most difficult species to distinguish by sight and song. Other pairs of species that had similar songs were Dark-eyed Juncos and Chipping Sparrows, and Mountain and Black-capped Chickadees. A few observers may have had difficulties with other species, such as some of the warblers or woodpeckers. These biases would increase the apparent breadth of cover type usage by some species if they were falsely reported in cover types where they are less likely to occur (such as Hammond's Flycatchers in clearcuts).

Each National Forest had two observers in each year, and usually a new set every year. In only four cases did observers cover the same National Forest for 2 years (conducting 19 to 37 percent of analyzed points on the forest), and none for 3 years. Overall, 66 percent of the point counts were conducted by observers who were employed for only 1 year. By cover type, the most dominant observer within each type accounted for 6 to 20 percent of the points in that type. Specifically, the cover types most dominated by a single observer were Grassland (19.7 percent), Cedar/Grand Fir (17.8 percent), Cottonwood/Aspen (17.0 percent), and Patch Cut (16.4 percent). Therefore, although interobserver biases were probably significant, no one observer dominated any given region or cover type. The less common cover types are, as usual, most vulnerable to such biases, especially the most regionally restricted ones such as Cedar/Grand Fir. 


\section{Bird Names}

Common and scientific bird names, as well as species order, follow the American Ornithologists' Union Check-list of North American Birds (1998). Species that were split into distinct species (for example, Solitary Vireo) after we collected our field data were identified on the basis of geographic range.

\section{Results}

We recorded bird and vegetation data from a single visit to each of 5,509 points in 1994 , and 6,144 points in 1995 , and 5,581 points in 1996 , on 708 permanently marked transects distributed across 12 National Forests in the Northern Region as well Bureau of Land Management and Potlatch lands, in addition to 762 nonpermanently marked points that were visited in 1994. Some transect locations were changed between years for logistical reasons. Thus, 428 transects were visited all 3 years, 184 transects were visited in 2 of the 3 years, and 96 transects were visited in only a single year. When nonriparian points within $100 \mathrm{~m}$ of an edge (as recorded by each field observer) were excluded, as well as some points with miscellaneous or unknown cover types, the final data set used in these habitat analyses consisted of 2,557 points in 1994 (470 permanent transects and 511 nonpermanent points), 2,473 points in 1995 ( 557 transects), and 2,251 points in 1996 (515 transects).

The distribution of points among cover types was fairly consistent among years (table 2). Twelve of the 18 cover types were represented by at least 50 points in all 3 years. Ponderosa Pine and Wetland categories had the poorest representation and might be considered the least reliably sampled cover types. It must also be reiterated that all three riparian categories were sampled at points that were within $100 \mathrm{~m}$ of the edge of another major cover type, so some bird detections may have been from within adjacent nonriparian cover types.

In the 3 years of data collected at all permanently marked monitoring points, we detected 195 bird species. Within $100 \mathrm{~m}$ of the points used in this report, we detected 166 species (table 3 ), most (128) of which were those that the point count method was designed to detect-the smaller, diurnal, visually, and vocally conspicuous landbirds. Also included were 22 waterbird species and 15 raptors. The 10 most frequently detected species were Dark-eyed Junco, Yellow-rumped Warbler, Red-breasted Nuthatch, Swainson's Thrush, Townsend's Warbler, Western Tanager, Ruby-crowned Kinglet, American Robin, Chipping Sparrow, and MacGillivray's Warbler (table 3).

We detected 54 species on at least 25 points in each of the 3 years, and 29 additional species with at least 30 total detections when all 1994 to 1996 data were pooled. For each species, we provide our subjective impression of the pattern of cover type use as well as specific comments on management implications of that distribution pattern below.

The error bars in the habitat distribution graphs show a wide range of variation in the probability if detection across the 3 years. As expected, less common species show more variation. Also, undersampled cover types, such as Ponderosa Pine and Wetlands, tend to have much larger error bars than well-sampled cover types such as Mixed Conifer. Beyond this, however, it is still apparent that some species have high and consistent probabilities in some cover types over others, illustrating distinctly nonrandom patterns of cover type use.

Table 3-Bird species detected on point counts conducted between 1994 and 1996 as part of the USDA Forest Service's Northern Region Landbird Monitoring Program, with the number of points (nonedge or riparian) at which each was detected within $100 \mathrm{~m}$ in each year. The order is based on the American Ornithologists' Union Checklist of North American Birds (1998).

\begin{tabular}{|c|c|c|c|c|}
\hline \multirow[b]{2}{*}{ Figure } & \multirow[b]{2}{*}{ Species } & \multicolumn{3}{|c|}{ Year of data collection } \\
\hline & & $\overline{1994}$ & 1995 & 1996 \\
\hline - & Red-necked Grebe, Podiceps grisegena & & 2 & \\
\hline - & American Bittern, Botaurus lentiginosus & & 1 & \\
\hline - & Great Blue Heron, Ardea herodias & 2 & & 1 \\
\hline - & Canada Goose, Branta canadensis & & 2 & 1 \\
\hline - & American Wigeon, Anas americana & & & 1 \\
\hline - & Mallard, Anas platyrhynchos & 1 & 9 & 2 \\
\hline- & Blue-winged Teal, Anas discors & & 1 & \\
\hline - & Cinnamon Teal, Anas cyanoptera & & 1 & \\
\hline - & Northern Shoveler, Anas clypeata & & & 1 \\
\hline - & Green-winged Teal, Anas crecca & & 1 & \\
\hline - & Ring-necked Duck, Aythya collaris & & 1 & \\
\hline- & Common Goldeneye, Bucephala clangula & & 2 & \\
\hline
\end{tabular}


Table 3 (Con.)

\begin{tabular}{|c|c|c|c|c|}
\hline \multirow[b]{2}{*}{ Figure } & \multirow[b]{2}{*}{ Species } & \multicolumn{3}{|c|}{ Year of data collection } \\
\hline & & 1994 & 1995 & 1996 \\
\hline- & Barrow's Goldeneye, Bucephala islandica & & & 1 \\
\hline - & Hooded Merganser, Lophodytes cucullatus & & 2 & \\
\hline- & Common Merganser, Mergus merganser & & 1 & \\
\hline- & Osprey, Pandion haliaetus & 6 & 2 & \\
\hline- & Bald Eagle, Haliaeetus leucocephalus & & 1 & \\
\hline- & Northern Harrier, Circus cyaneus & & & 1 \\
\hline- & Sharp-shinned Hawk, Accipiter striatus & 4 & 1 & 4 \\
\hline- & Cooper's Hawk, Accipiter cooperii & 3 & 2 & 2 \\
\hline - & Northern Goshawk, Accipiter gentilis & 4 & & \\
\hline- & Swainson's Hawk, Buteo swainsoni & & 1 & 1 \\
\hline 8 & Red-tailed Hawk, Buteo jamaicensis & 18 & 13 & 15 \\
\hline 9 & American Kestrel, Falco sparverius & 23 & 10 & 8 \\
\hline- & Prairie Falcon, Falco mexicanus & & & 1 \\
\hline - & Gray Partridge, Perdix perdix & 1 & & \\
\hline- & Ring-necked Pheasant, Phasianus colchicus & 1 & & \\
\hline 10 & Blue Grouse, Dendragapus obscurus & 9 & 14 & 7 \\
\hline- & Spruce Grouse, Falcipennis canadensis & 2 & 1 & 1 \\
\hline 11 & Ruffed Grouse, Bonasa umbellus & 61 & 92 & 76 \\
\hline- & Wild Turkey, Meleagris gallopavo & 1 & 1 & \\
\hline- & Mountain Quail, Oreortyx pictus & & 2 & \\
\hline 一 & California Quail, Callipepla californica & 1 & & 1 \\
\hline - & Sora, Porzana carolina & & 5 & \\
\hline - & American Coot, Fulica americana & & 1 & \\
\hline- & Sandhill Crane, Grus canadensis & 2 & 1 & 3 \\
\hline - & Killdeer, Charadrius vociferus & 7 & 3 & 1 \\
\hline - & Spotted Sandpiper, Actitis macularia & 7 & 10 & 5 \\
\hline - & Long-billed Curlew, Numenius americanus & 3 & 1 & 1 \\
\hline 12 & Common Snipe, Gallinago gallinago ${ }^{\mathrm{a}}$ & 22 & 27 & 11 \\
\hline- & Rock Dove, Columba livia & 1 & & \\
\hline 13 & Mourning Dove, Zenaida macroura & 26 & 7 & 14 \\
\hline - & Flammulated Owl, Otus flammeolus & 1 & 1 & 1 \\
\hline- & Great Horned Owl, Bubo virginianus & 1 & & 1 \\
\hline - & Northern Pygmy-Owl, Glaucidium gnoma & 2 & 1 & 4 \\
\hline- & Barred Owl, Strix varia & 1 & & \\
\hline - & Short-eared Owl, Asio flammeus & 1 & & \\
\hline- & Common Nighthawk, Chordeiles minor ${ }^{\mathrm{a}}$ & 13 & 5 & 6 \\
\hline 14 & Vaux's Swift, Chaetura vaux ${ }^{a}$ & 10 & 14 & 17 \\
\hline 15 & Calliope Hummingbird, Stellula calliope & 23 & 10 & 6 \\
\hline- & Broad-tailed Hummingbird, Selasphorus platycercus & 1 & & \\
\hline 16 & Rufous Hummingbird, Selasphorus rufus & 33 & 19 & 28 \\
\hline - & Belted Kingfisher, Ceryle alcyon & 3 & 1 & 4 \\
\hline- & Lewis' Woodpecker, Melanerpes lewis & 3 & 2 & 2 \\
\hline - & Yellow-bellied Sapsucker, Sphyrapicus varius & 1 & & \\
\hline 17 & Red-naped Sapsucker, Sphyrapicus nuchalis & 90 & 70 & 44 \\
\hline 18 & Williamson's Sapsucker, Sphyrapicus thyroideus & 18 & 23 & 11 \\
\hline- & Downy Woodpecker, Picoides pubescens & 13 & 8 & 5 \\
\hline 19 & Hairy Woodpecker, Picoides villosus & 65 & 55 & 58 \\
\hline 20 & Three-Toed Woodpecker, Picoides tridactylus & 18 & 8 & 9 \\
\hline- & Black-backed Woodpecker, Picoides arcticus & 1 & 1 & 1 \\
\hline 21 & Northern Flicker, Colaptes auratus & 251 & 166 & 111 \\
\hline 22 & Pileated Woodpecker, Dryocopus pileatus & 61 & 51 & 26 \\
\hline 23 & Olive-sided Flycatcher, Contopus cooperi & 88 & 62 & 58 \\
\hline 24 & Western Wood-Pewee, Contopus sordidulus & 24 & 14 & 11 \\
\hline 25 & Willow Flycatcher, Empidonax trailii & 52 & 19 & 23 \\
\hline- & Least Flycatcher, Empidonax minimus & 1 & 10 & 1 \\
\hline 26 & Hammond's Flycatcher, Empidonax hammondii & 156 & 126 & 104 \\
\hline 27 & Dusky Flycatcher, Empidonax oberholseri & 317 & 245 & 227 \\
\hline
\end{tabular}


Table 3 (Con.)

\begin{tabular}{|c|c|c|c|c|}
\hline \multirow[b]{2}{*}{ Figure } & \multirow[b]{2}{*}{ Species } & \multicolumn{3}{|c|}{ Year of data collection } \\
\hline & & $\overline{1994}$ & 1995 & 1996 \\
\hline 28 & Cordilleran Flycatcher, Empidonax occidentalis & 32 & 10 & 1 \\
\hline - & Say's Phoebe, Sayornis saya & & & 1 \\
\hline - & Western Kingbird, Tyrannus verticalis & 1 & & \\
\hline- & Eastern Kingbird, Tyrannus tyrannus & 13 & 2 & \\
\hline 29 & Cassin's Vireo, Vireo cassinii & 306 & 234 & 227 \\
\hline 31 & Warbling Vireo, Vireo gilvus & 387 & 382 & 348 \\
\hline 32 & Red-eyed Vireo, Vireo olivaceus & 24 & 11 & 11 \\
\hline 33 & Gray Jay, Perisoreus canadensis & 150 & 114 & 122 \\
\hline 34 & Steller's Jay, Cyanocitta stelleri & 74 & 43 & 53 \\
\hline 35 & Clark's Nutcracker, Nucifraga columbiana & 109 & 63 & 62 \\
\hline- & Black-billed Magpie, Pica pica & 10 & 3 & 4 \\
\hline- & American Crow, Corvus brachyrhynchos & 3 & 4 & 5 \\
\hline 36 & Common Raven, Corvus corax & 62 & 34 & 40 \\
\hline 37 & Horned Lark, Eremophila alpestris & 30 & 27 & 20 \\
\hline 38 & Tree Swallow, Tachycineta bicolor ${ }^{a}$ & 40 & 43 & 23 \\
\hline 39 & Violet-green Swallow, Tachycineta thalassina ${ }^{\mathrm{a}}$ & 7 & 14 & 10 \\
\hline - & N. Rough-winged Swallow, Stelgidopteryx serripennis ${ }^{a}$ & 11 & 4 & 5 \\
\hline - & Bank Swallow, Riparia riparia ${ }^{\mathrm{a}}$ & 2 & & 2 \\
\hline - & Cliff Swallow, Petrochelidon pyrrhonota ${ }^{a}$ & 10 & 7 & 2 \\
\hline - & Barn Swallow, Hirundo rustica ${ }^{\mathrm{a}}$ & 10 & 7 & 1 \\
\hline 40 & Black-capped Chickadee, Poecile atricapillus & 94 & 124 & 120 \\
\hline 42 & Mountain Chickadee, Poecile gambeli & 437 & 477 & 376 \\
\hline 43 & Chestnut-backed Chickadee, Poecile rufescens & 102 & 85 & 109 \\
\hline- & Boreal Chickadee, Poecile hudsonicus & 1 & 3 & 2 \\
\hline 45 & Red-breasted Nuthatch, Sitta canadensis & 994 & 805 & 772 \\
\hline 46 & White-breasted Nuthatch, Sitta carolinensis & 25 & 21 & 16 \\
\hline - & Pygmy Nuthatch, Sitta pygmaea & & & 1 \\
\hline 47 & Brown Creeper, Certhia americana & 33 & 42 & 57 \\
\hline 49 & Rock Wren, Salpinctes obsoletus & 19 & 10 & 22 \\
\hline - & Canyon Wren, Catherpes mexicanus & & & 3 \\
\hline 50 & House Wren, Troglodytes aedon & 60 & 48 & 33 \\
\hline 51 & Winter Wren, Troglodytes troglodytes & 137 & 196 & 164 \\
\hline - & Marsh Wren, Cistothorus palustris & 1 & 2 & 2 \\
\hline - & American Dipper, Cinclus mexicanus & 3 & 1 & 5 \\
\hline 54 & Golden-crowned Kinglet, Regulus satrapa & 408 & 506 & 383 \\
\hline 55 & Ruby-crowned Kinglet, Regulus calendula & 591 & 586 & 465 \\
\hline - & Western Bluebird, Sialia mexicana & 1 & & \\
\hline 57 & Mountain Bluebird, Sialia currucoides & 74 & 65 & 37 \\
\hline 58 & Townsend's Solitaire, Myadestes townsendi & 275 & 199 & 178 \\
\hline - & Veery, Catharus fuscescens & 8 & 8 & 8 \\
\hline 59 & Swainson's Thrush, Catharus ustulatus & 733 & 565 & 543 \\
\hline 61 & Hermit Thrush, Catharus guttatus & 126 & 102 & 119 \\
\hline 63 & American Robin, Turdus migratorius & 624 & 538 & 403 \\
\hline 64 & Varied Thrush, Ixoreus naevius & 209 & 266 & 152 \\
\hline - & Gray Catbird, Dumetella carolinensis & 14 & 5 & 5 \\
\hline - & Sage Thrasher, Oreoscoptes montanus & & 8 & 4 \\
\hline - & European Starling, Sturnus vulgaris & 21 & 3 & 1 \\
\hline 65 & Cedar Waxwing, Bombycilla cedrorum & 23 & 12 & 18 \\
\hline - & Tennessee Warbler, Vermivora peregrina & & 2 & \\
\hline 66 & Orange-crowned Warbler, Vermivora celata & 217 & 176 & 171 \\
\hline 67 & Nashville Warbler, Vermivora ruficapilla & 49 & 54 & 37 \\
\hline 69 & Yellow Warbler, Dendroica petechia & 101 & 74 & 57 \\
\hline 70 & Yellow-rumped Warbler, Dendroica coronata & 1022 & 932 & 764 \\
\hline 71 & Townsend's Warbler, Dendroica townsendi & 614 & 611 & 599 \\
\hline - & Blackpoll Warbler, Dendroica striata & 1 & & \\
\hline 72 & American Redstart, Setophaga ruticilla & 22 & 30 & 15 \\
\hline 73 & Ovenbird, Seiurus aurocapillus & 15 & 12 & 9 \\
\hline
\end{tabular}

(con.) 
Table 3 (Con.)

\begin{tabular}{|c|c|c|c|c|}
\hline \multirow[b]{2}{*}{ Figure } & \multirow[b]{2}{*}{ Species } & \multicolumn{3}{|c|}{ Year of data collection } \\
\hline & & 1994 & 1995 & 1996 \\
\hline 74 & Northern Waterthrush, Seiurus noveboracensis & 26 & 21 & 27 \\
\hline 一 & Mourning Warbler, Oporornis philadelphia & 1 & & \\
\hline 75 & MacGillivray's Warbler, Oporornis tolmiei & 537 & 419 & 448 \\
\hline 76 & Common Yellowthroat, Geothlypis trichas & 26 & 38 & 34 \\
\hline 77 & Wilson's Warbler, Wilsonia pusilla & 74 & 76 & 108 \\
\hline \multirow[t]{2}{*}{-} & Yellow-breasted Chat, Icteria virens & & 1 & \\
\hline & Western Tanager, Piranga ludoviciana & 663 & 486 & 542 \\
\hline 80 & Green-tailed Towhee, Pipilo chlorurus & 18 & 23 & 8 \\
\hline 81 & Spotted Towhee, Pipilo maculatus & 51 & 65 & 61 \\
\hline 82 & Chipping Sparrow, Spizella passerina & 698 & 480 & 350 \\
\hline- & Clay-colored Sparrow, Spizella pallida & 1 & & 2 \\
\hline 83 & Brewer's Sparrow, Spizella breweri & 47 & 14 & 19 \\
\hline - & Field Sparrow, Spizella pusilla & & & 1 \\
\hline 84 & Vesper Sparrow, Pooecetes gramineus & 178 & 146 & 101 \\
\hline - & Lark Sparrow, Chondestes grammacus & 4 & & 8 \\
\hline 85 & Savannah Sparrow, Passerculus sandwichensis & 40 & 29 & 26 \\
\hline 86 & Grasshopper Sparrow, Ammodramus savannarum & 29 & & 1 \\
\hline 87 & Fox Sparrow, Passerella iliaca & 99 & 128 & 91 \\
\hline 88 & Song Sparrow, Melospiza melodia & 135 & 110 & 124 \\
\hline 89 & Lincoln's Sparrow, Melospiza lincolnii & 22 & 34 & 38 \\
\hline 90 & White-crowned Sparrow, Zonotrichia leucophrys & 38 & 43 & 53 \\
\hline 91 & Dark-eyed Junco, Junco hyemalis & 1295 & 1100 & 1082 \\
\hline 92 & Black-headed Grosbeak, Pheucticus melanocephalus & 73 & 55 & 69 \\
\hline 93 & Lazuli Bunting, Passerina amoena & 57 & 51 & 46 \\
\hline- & Bobolink, Dolichonyx oryzivorus & 2 & & \\
\hline 94 & Red-winged Blackbird, Agelaius phoeniceus & 19 & 12 & 4 \\
\hline 95 & Western Meadowlark, Sturnella neglecta & 137 & 65 & 42 \\
\hline - & Yellow-headed Blackbird, Xanthocephalus xanthocephalus & 2 & 4 & \\
\hline - & Brewer's Blackbird, Euphagus cyanocephalus & 15 & 13 & 1 \\
\hline 96 & Brown-headed Cowbird, Molothrus ater & 190 & 120 & 85 \\
\hline - & Bullock's Oriole, Icterus bullockii & 6 & & \\
\hline 97 & Pine Grosbeak, Pinicola enucleator & 20 & 14 & 15 \\
\hline 98 & Cassin's Finch, Carpodacus cassinii & 83 & 74 & 36 \\
\hline- & House Finch, Carpodacus mexicanus & 1 & & \\
\hline 99 & Red Crossbill, Loxia curvirostra & 75 & 59 & 162 \\
\hline- & White-winged Crossbill, Loxia leucoptera & 2 & 13 & 3 \\
\hline 100 & Pine Siskin, Carduelis pinus & 224 & 332 & 594 \\
\hline - & American Goldfinch, Carduelis tristis & 6 & 5 & 7 \\
\hline 101 & Evening Grosbeak, Coccothraustes vespertinus & 39 & 36 & 49 \\
\hline \multirow{2}{*}{-} & House Sparrow, Passer domesticus & 2 & & \\
\hline & Total number of point counts & 2557 & 2473 & 2251 \\
\hline
\end{tabular}

${ }^{a}$ Flyovers included for these species. 


\section{Species Accounts}

Figures 8 through 101 show the percent of 10 -minute point counts with at least one detection of each subject bird. Bars represent data from all 3 years combined, and some figures (for example, fig. 11) contain error bars that represent the standard deviation.

Red-tailed Hawks (fig. 8) were detected on 46 points in all 3 years combined. As a wide-ranging predator with large territories, this species can be found in many cover types. Although based on few detections, the high occurrence in open Ponderosa Pine and harvested stands is biologically logical in light of a need for open areas to hunt small mammals, as well as large trees for nesting. This, in turn, suggests that the restoration of much of the lower elevation ponderosa pine to more open park-like conditions may benefit this species.
Figure 8

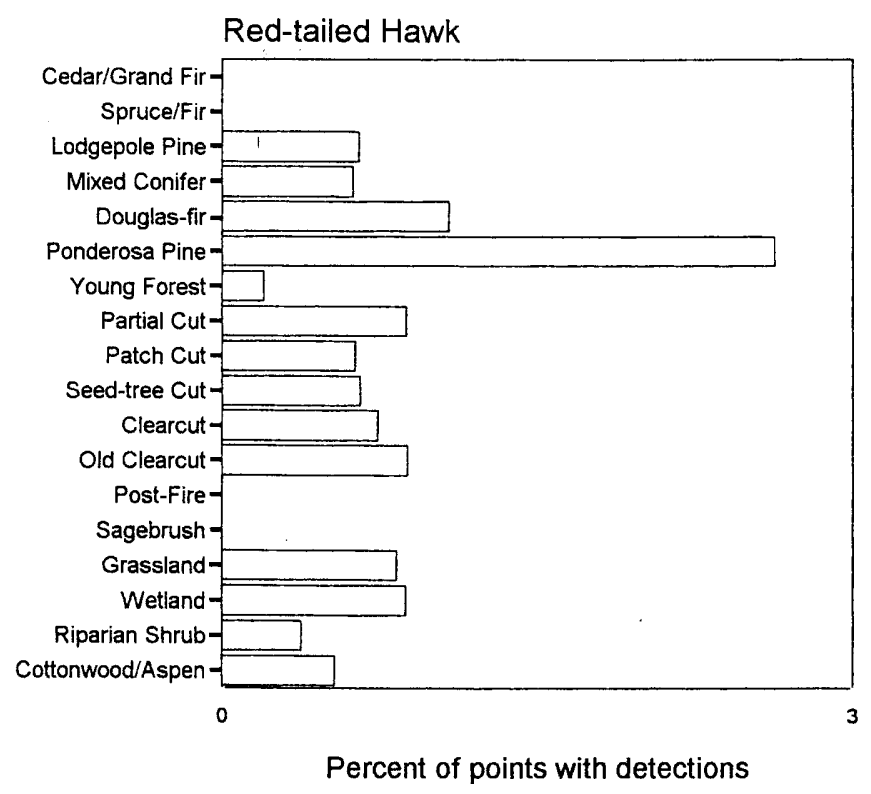

Figure 9 country, cavity-nesting birds that need large dead or dying trees for nesting purposes. They were most frequently detected in open areas that have large trees scattered throughout, including cottonwood bottomlands and heavily cut forests (and in agricultural lands, as recorded in additional surveys not reported here). The abundance of this species in relatively heavily cut forests appears, on the surface, to reflect a high suitability of these forests to kestrels. However, because there are numerous aspects of harvested forests that are not typical of similar conditions created through natural processes, those areas could also be acting as ecological traps; we need data on reproductive success to determine whether harvested forests are as suitable as suggested by the occurrence data.
American Kestrel

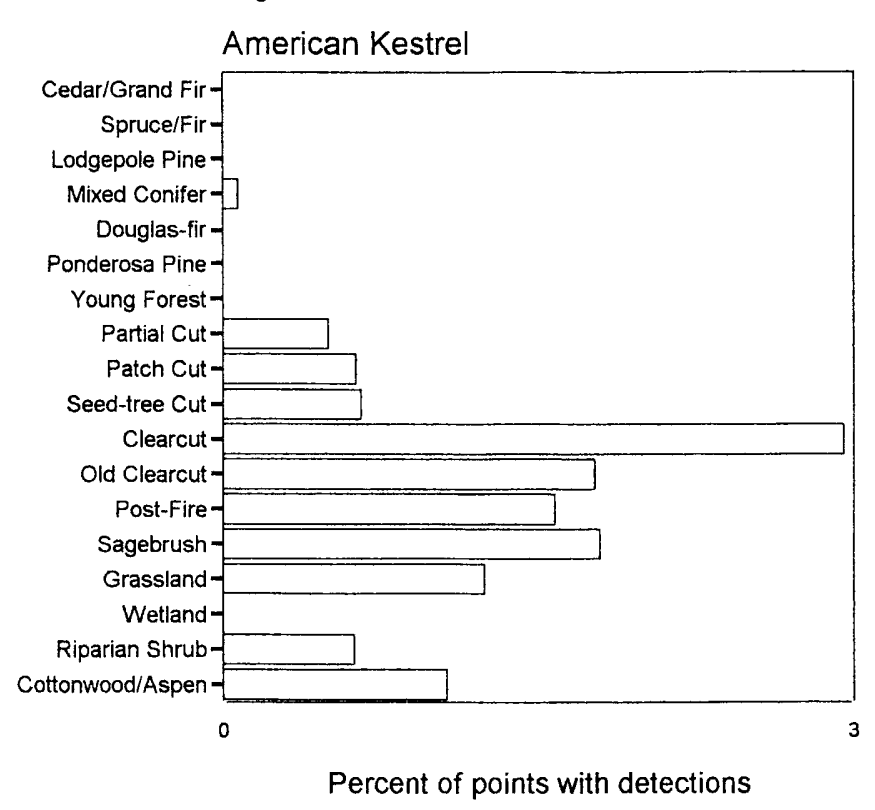


Blue Grouse (fig. 10) were detected on only 30 of the points in all 3 years combined, so the details of its pattern of cover type use may not be entirely accurate. Nonetheless, the pattern agrees with existing literature, which suggests that they are most common in open conifer forests (Zwickel 1992). The detections in Sagebrush are interesting, but involved only three transects, two of which were over 7,000 feet elevation. Zwickel (1992) stated that the species may occur in shrubsteppe and grassland communities out to $2 \mathrm{~km}$ or more from conifer forest edge, but it requires nearby conifer forest for winter foraging habitat. No special management considerations are suggested by the data.

Ruffed Grouse (fig. 11) were detected on 61, 92, and 76 of the points in the 3 years. They were detected with highest probability in aspen (12 percent of points with detections) and other riparian cover types. Although this species is primarily associated with riparian areas in the West, it was recorded in a variety of additional cover types as well. This species may use shrubby or other deciduous microhabitats within cut or uncut forests, and it would be helpful to know what is required for successful use of such areas. We also suspect that detections were recorded in nonriparian cover types due to a failure to detect the streamside riparian cover type within which they were drumming. Such error is especially likely for this species because of its low-pitch drumming, which makes it difficult to estimate location and distance.

Ruffed Grouse were much more likely to drum early than late in the breeding season. Detections declined rapidly after the first week, becoming rare by the fourth week of June (fig. 5b). Eighty percent of the detections occurred by June 11, but when the data were restricted to this period (not shown), the relative probabilities of detection in all cover types did not change significantly, except for an artificially high estimate for Spruce/Fir (due to two detections out of only 11 Spruce/Fir points). Because Ruffed Grouse were rarely drumming when Spruce/Fir was sampled later in the season, the estimate for this species in Spruce/ Fir is suspect, although it is still expected to be low.

Because this species is relatively restricted to riparian corridors, the main concern should be whether riparian management practices are compatible with its needs. We need nesting success data in relation to alternative streamside management scenarios (especially cattle grazing, which may, through mechanical damage, remove the cover needed for suitable display sites).
Figure 10

Blue Grouse

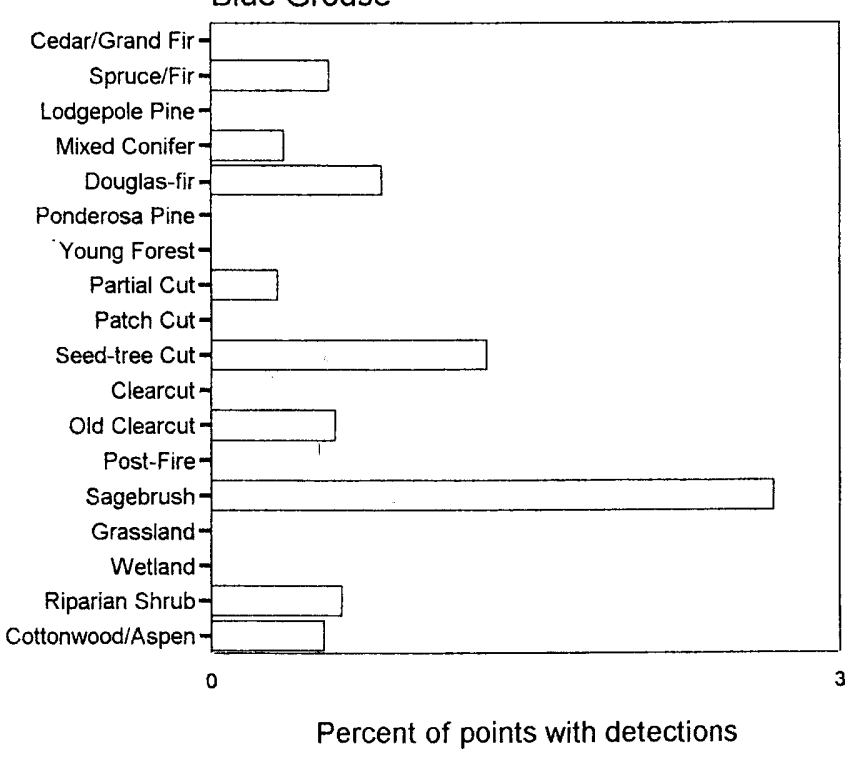

Figure 11

Ruffed Grouse

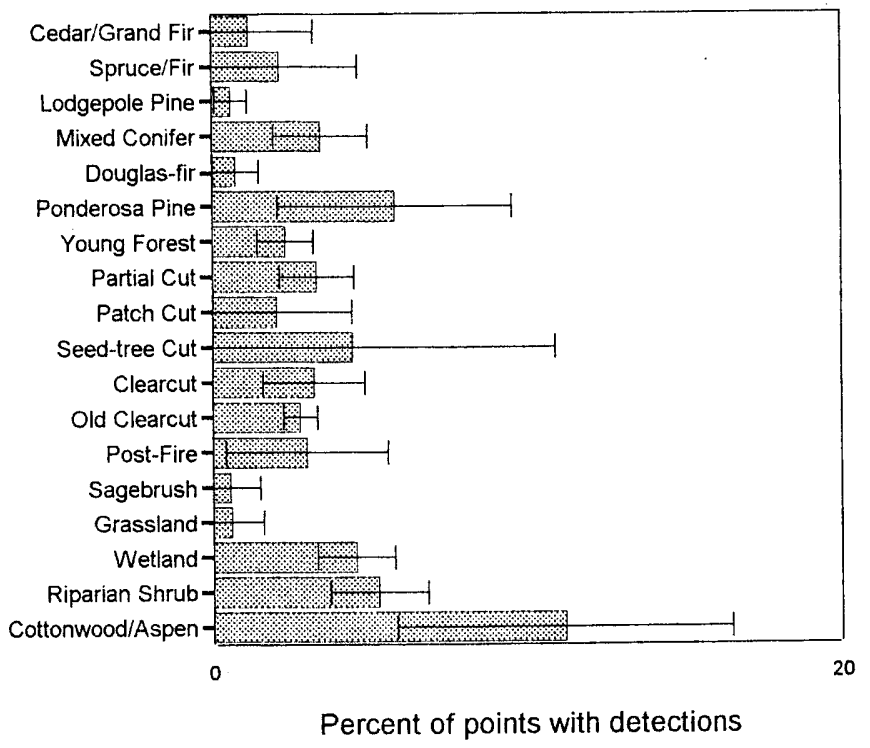

Percent of points with detections 
Common Snipe (fig. 12) were detected on 60 of the points in all 3 years combined, and were relatively restricted to Wetlands, but were also detected moderately often in Grassland (and in agricultural lands, as recorded in additional surveys not reported here). They generally nest adjacent to marshes, flooded fields, and bogs (Paulson 1993), and often perform their aerial display over adjacent grasslands or irrigated agricultural fields. No management considerations are suggested by the data independent of the widespread conversion of wetlands to drier (less suitable) agricultural land and the possible destruction of nests due to use of agricultural machinery during the nesting season. the points in all 3 years combined. This is a lowelevation, open-country species that nests in Cottonwood/Aspen, Ponderosa Pine forests, and trees and shrubs associated with agricultural land and Grassland. No special management considerations are suggested by the data.
Figure 12

Common Snipe

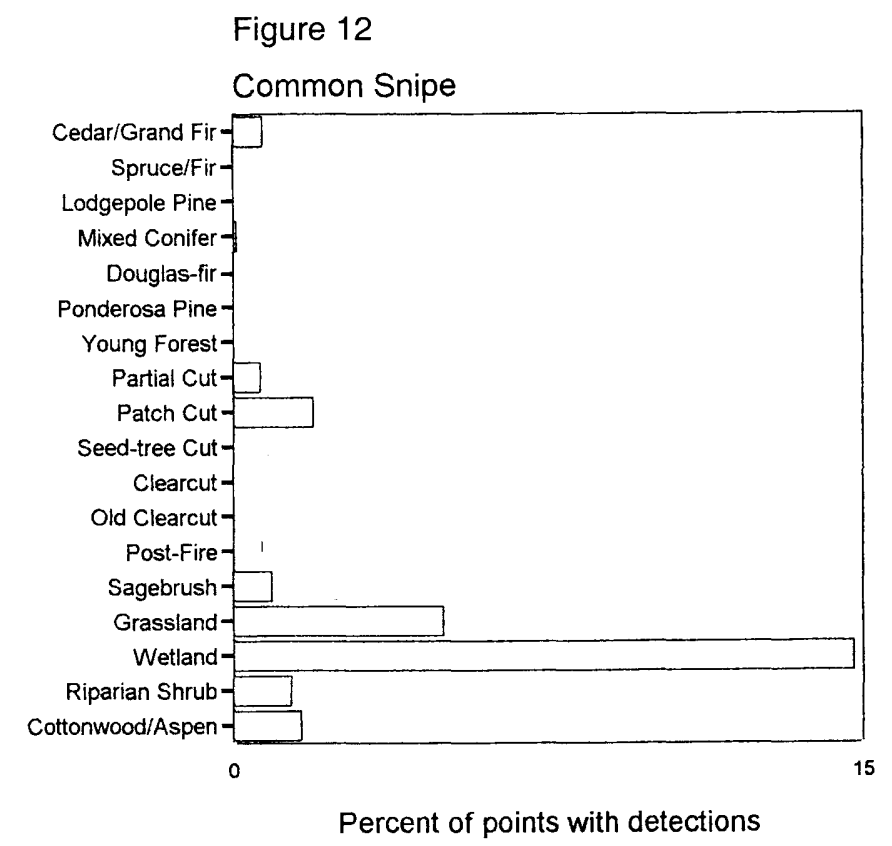

Figure 13

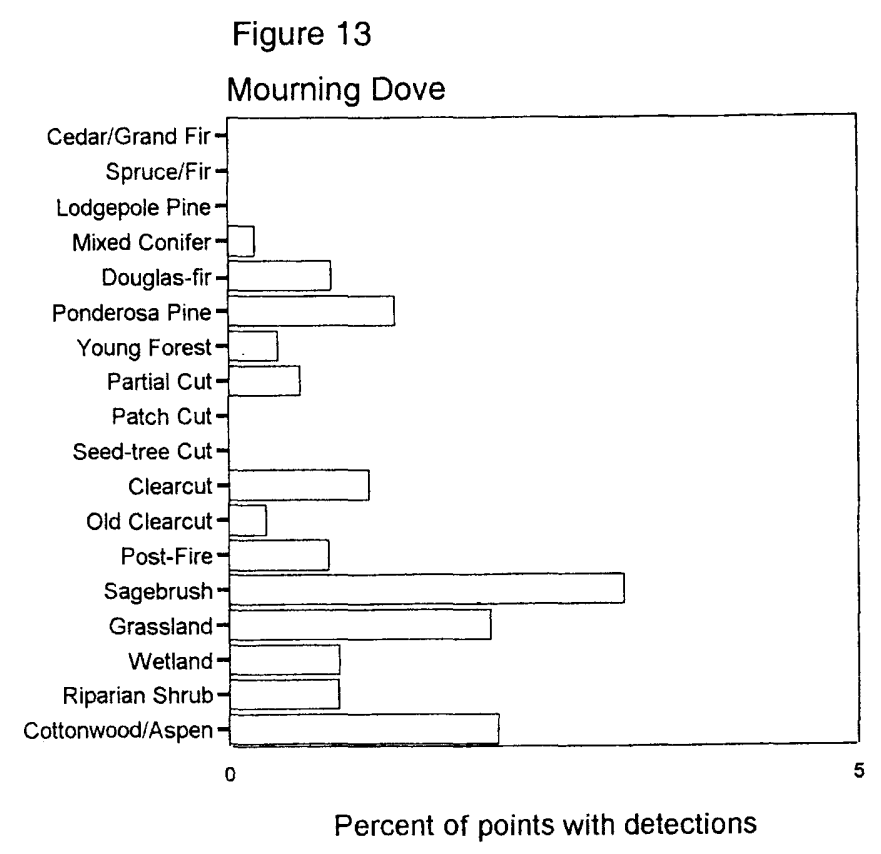


Vaux's Swifts (fig. 14) were detected on 41 of the points in all 3 years combined, including flyover data. They were seen foraging over logged stands as well as many uncut areas. The data are simply too sparse to give a clear picture of which undisturbed cover types are of primary importance to this species (the bar in Cedar/Grand Fir represents detections at only two points), especially because many detections were in foraging areas that were probably different from nesting habitats. Under natural conditions, they rely on large, hollow snags for nesting (Bull and Cooper 1991). In a Washington study they were common in Douglas-fir forests, where they appeared to be dependent on old growth conditions (Manuwal 1991). We need more information on the conditions that provide for suitable nest sites for this species.
Figure 14

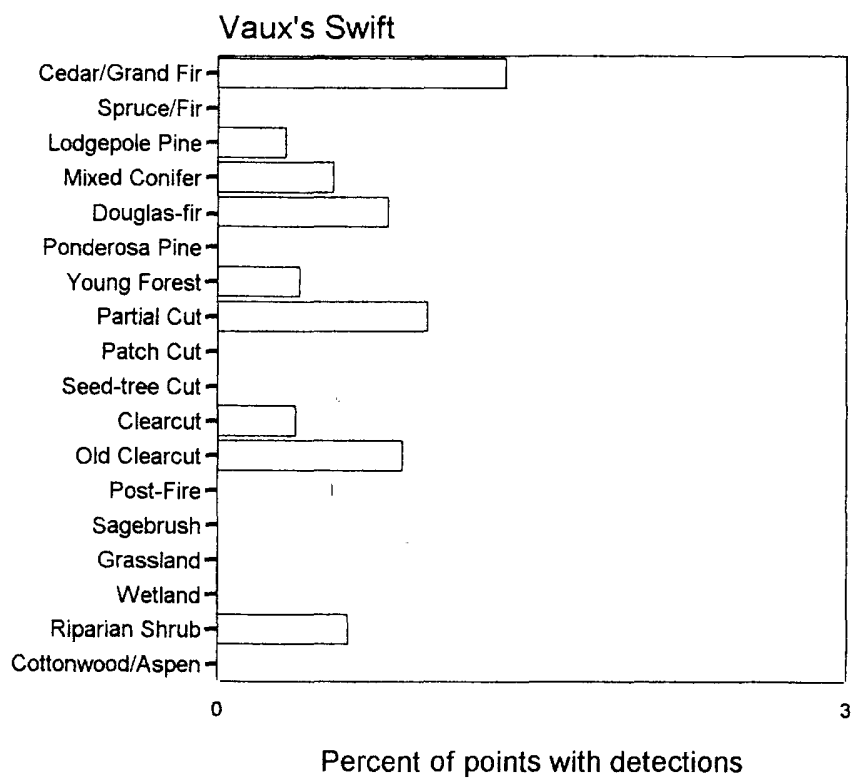

Figure 15

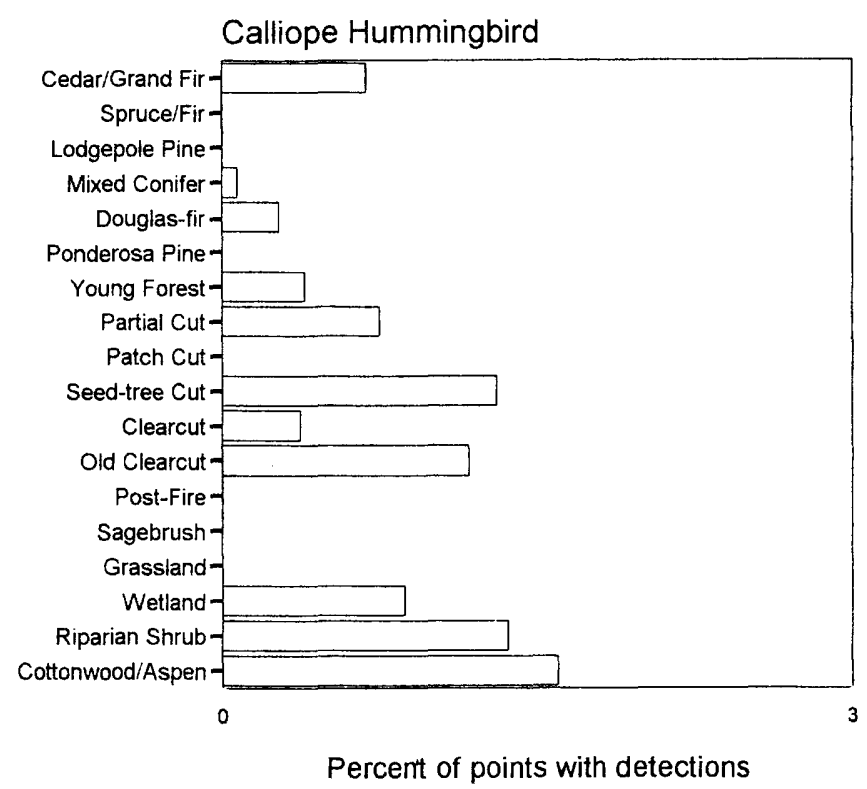


Rufous Hummingbirds (fig. 16) were detected on 80 of the points in all 3 years combined, primarily in early successional, postharvest situations (after shrubs have become abundant again). A larger study of postfire forests (Hutto 1995) indicated a higher probability of detection than we obtained in that cover type in this study. When data were restricted to the westside of the Continental Divide, where all but three detections of this species occurred, riparian cover types were shown to be used more frequently than indicated in figure 16 . This is one of seven bird species that revealed a significant population decline in the West from 1968 to 1991, according to the Breeding Bird Survey database (Hejl 1994). The main management concern here lies with whether the nesting success of birds that use the artificially created forest types (for example, Clearcuts and Seed-tree Cuts) are comparable with nesting success in the naturally occurring early successional postfire habitat. If not, the harvested types could be acting as "ecological traps" by attracting the birds, but then failing to provide other necessary resources.

Red-naped Sapsuckers (fig. 17) were detected on 90,77 , and 44 points in the 3 years, primarily in harvested conifer forests and riparian cover types. It is likely that the birds detected in the drier uncut conifer forest types were associated with deciduous trees (such as birch) that occur sparsely throughout the more moist northwestern forests. The relative abundance in cut forests is undoubtedly due to the presence of deciduous vegetation there as well. The apparent suitability of harvested conifer forests to Red-naped Sapsuckers could be misleading if they do not do well there in terms of reproductive success. Fortunately, published information based on a study conducted in Coram Experimental Forest, Montana, revealed that nest success did not differ significantly between unharvested and harvested forest plots (Tobalske 1992, Tobalske and others 1990).
Figure 16

Rufous Hummingbird

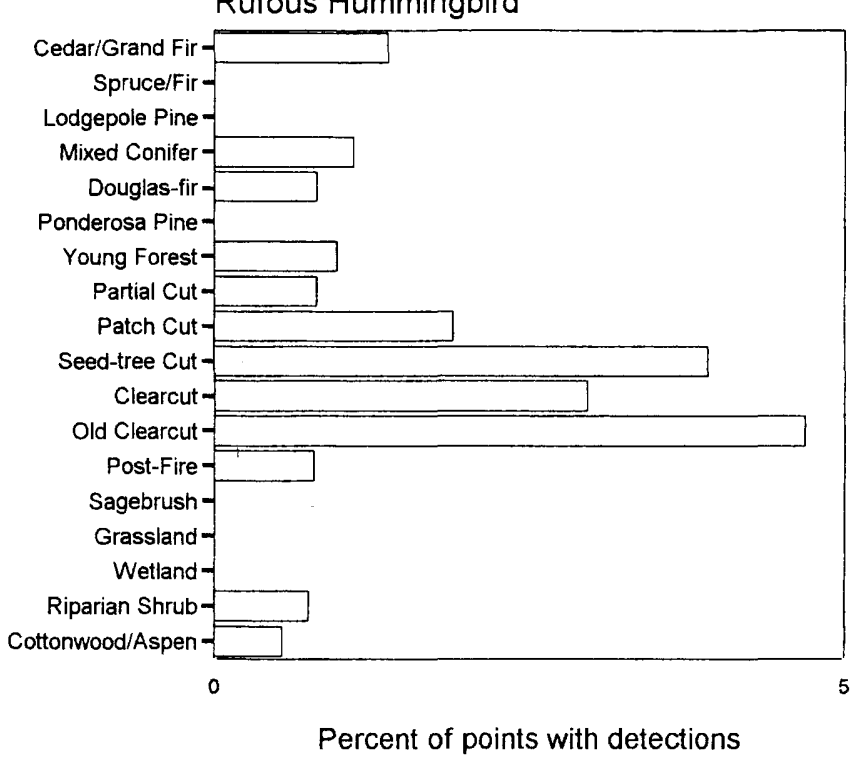

Figure 17

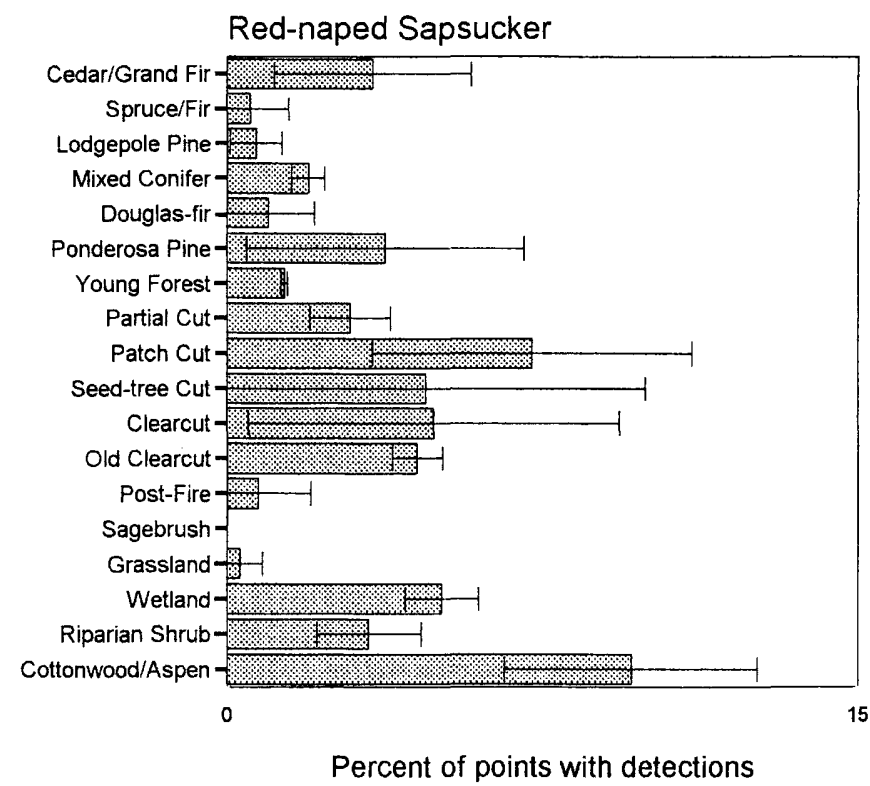


Williamson's Sapsuckers (fig. 18) were detected on 52 of the points in all 3 years combined, primarily in the more heavily harvested conifer forest types that still retained some green trees. Williamson's Sapsucker provides the most graphic example of a species that is more abundant in harvested forest cover types than anywhere else. This would appear, on the surface, to be a benefit of harvesting activity, but we would need information on nesting or survival success before we could conclude such. Because harvested forests are artificial in a number of respects, there is a chance that the proper visual stimuli exist to attract birds to settle, but that they then do poorly because other necessary requisites are not provided. In other words, there is a chance that these unnatural forests are acting as "ecological traps."

Hairy Woodpeckers (fig. 19) were detected on 65, 55 , and 58 of the points in the 3 years. As with most woodpeckers, which are infrequently detected and have large home ranges, the error bars for the detection probabilities of this species tended to be large. Hairy Woodpeckers were detected in most forest types, including aspen forests and associated wetlands, although they were generally more frequently in cut than in uncut forests. They were detected most frequently in early Post-Fire forests (although there is considerable variation about that mean in this study, the trend is also strongly supported by Hutto, 1995). Saab and Dudley (1998) found this species to be less abundant and have lower nesting success in salvage-logged stands relative to unlogged postfire forests. The relative abundance in cut stands may indicate that Hairy Woodpeckers are being drawn into such forests because of the superficial similarity of those conditions to burned forests. Whether the birds do well in the artificially created Partial Cut situations is unknown. If not, then that forest type (and possibly other cut forests) may be acting as "ecological traps."
Figure 18

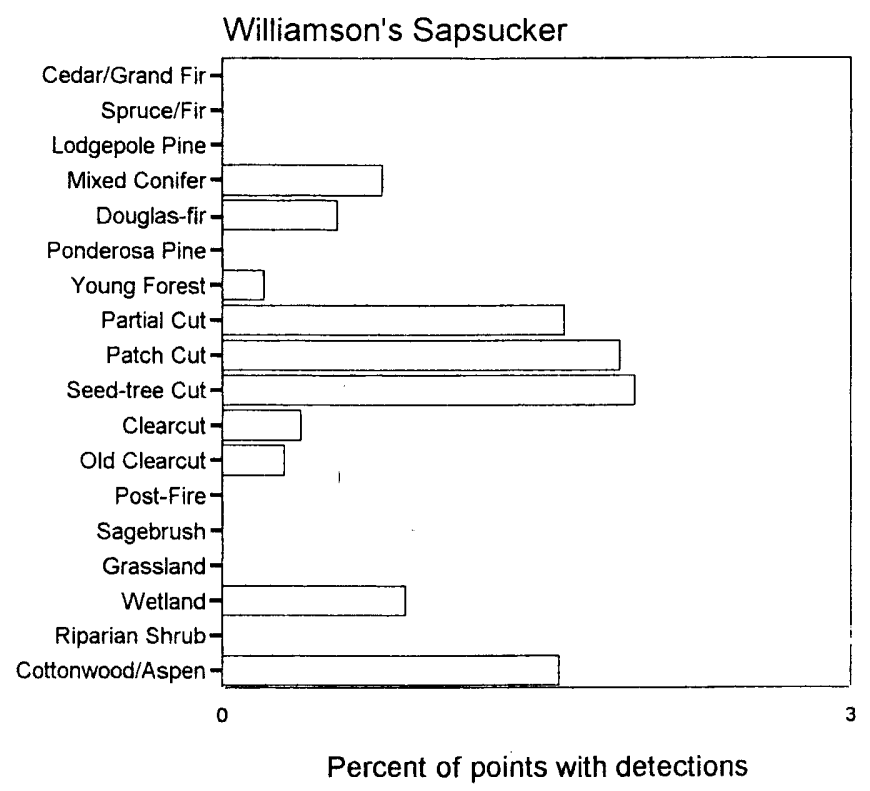

Figure 19

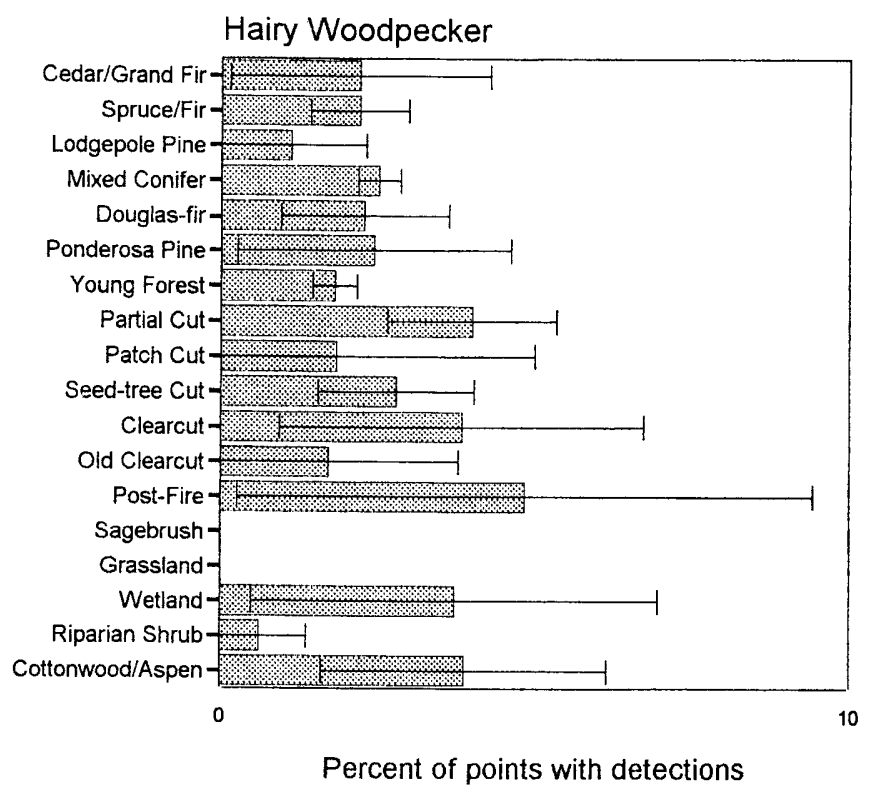


Three-toed Woodpeckers (fig. 20) were detected on 35 of the points in all 3 years combined, most frequently in Post-Fire. They were not quite as restricted to such conditions as the Black-backed Woodpecker (Hutto 1995) because they occurred fairly frequently in Spruce/Fir stands as well, but it is clear that postfire conditions are important to this species, which relies on dead or dying standing timber for feeding and nesting purposes. Postfire salvage logging is an activity that may be in conflict with the needs of this species (see also Caton 1996, Hitchcox 1996).
Figure 20

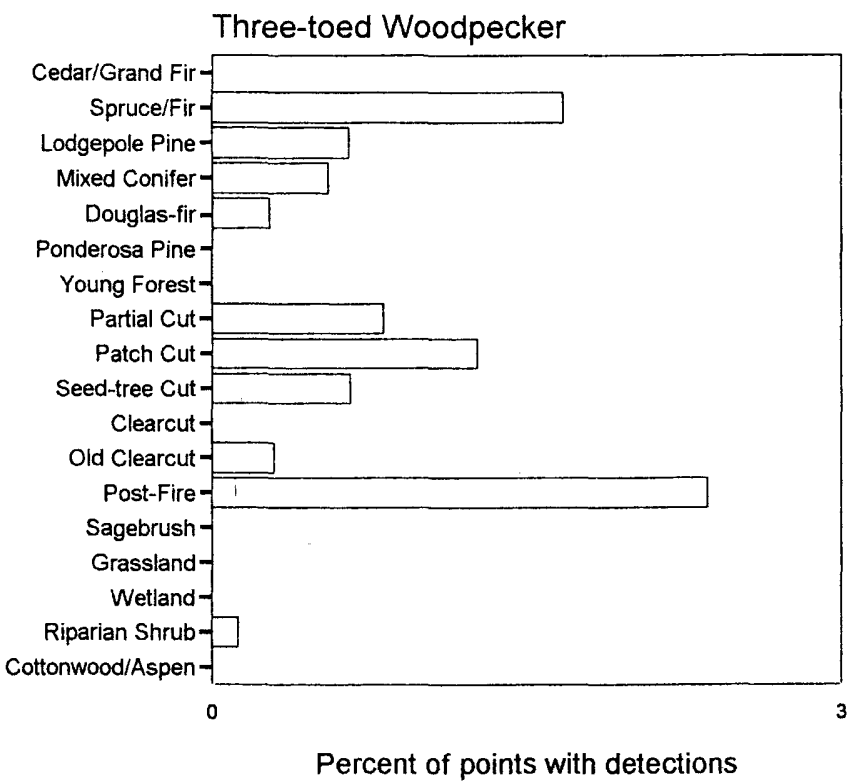

Figure 21

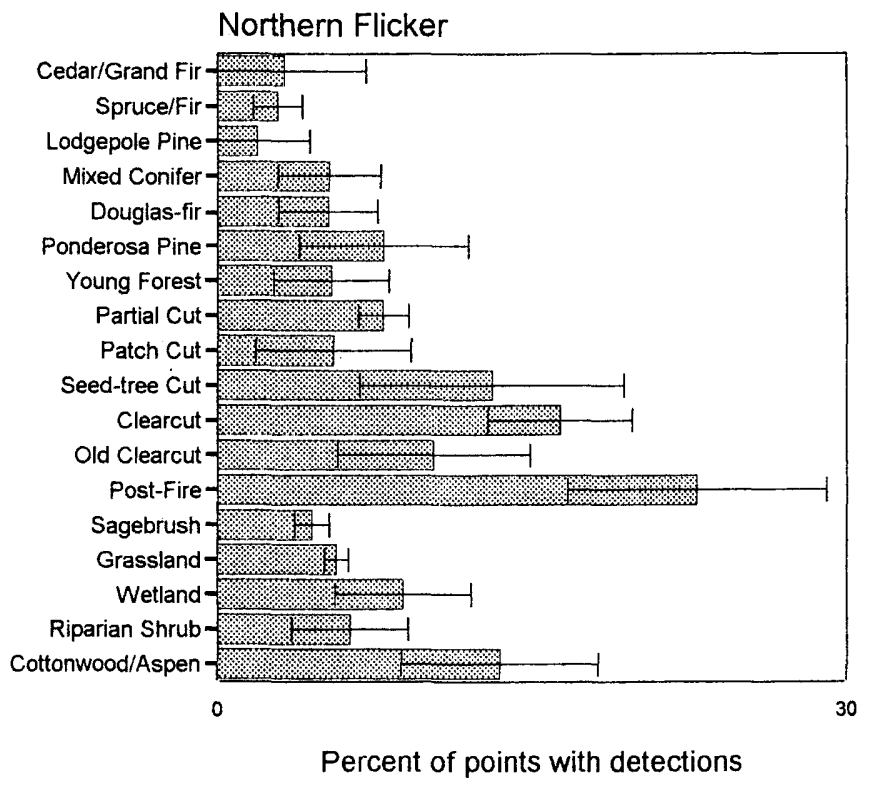


Pileated Woodpeckers (fig. 22) were detected on 61,51 , and 26 of the points in the 3 years. This is an uncommon species with large territories encompassing many cover types, so the specific locations of observations may not reflect cover type use per se. This was probably the reason for the large standard deviations around the estimates. This species was detected in both uncut and cut mid-elevation conifer forests, but its abundance in harvested forest types may have been, in part, a consequence of their mobility. They need large trees in the relatively uncut stands for nesting and roosting purposes (Bull and others 1992, Bull and Holthausen 1993).

We detected Pileated Woodpeckers in a somewhat higher percentage of old growth relative to mature conifer forests (3.9 percent versus 2.2 percent, $\mathrm{p}=$ 0.082 ). This species appears to do well in a matrix of forest types, but the inclusion of some older forest with large trees in their territories is probably necessary (Bull and Holthausen 1993). There was probably an intact forest near wherever these birds were detected (though not necessarily within $100 \mathrm{~m}$ ). Thus, detecting them in Clearcuts and Seed-tree Cuts should not be taken to mean they can do well in large, homogeneous stands of those kinds, or even in landscapes with a preponderance of cut units.

Pileated Woodpeckers were rarely detected east of the Continental Divide. There was only one detection in the database used here (and only 19, out of 6738 points, in all data). The Montana Bird Distribution Committee (1996) indicates that this is indeed a restriction of geographical distribution. Therefore, we determined its pattern of occurrence using only the westside data, but found no appreciable differences.
Figure 22

Pileated Woodpecker

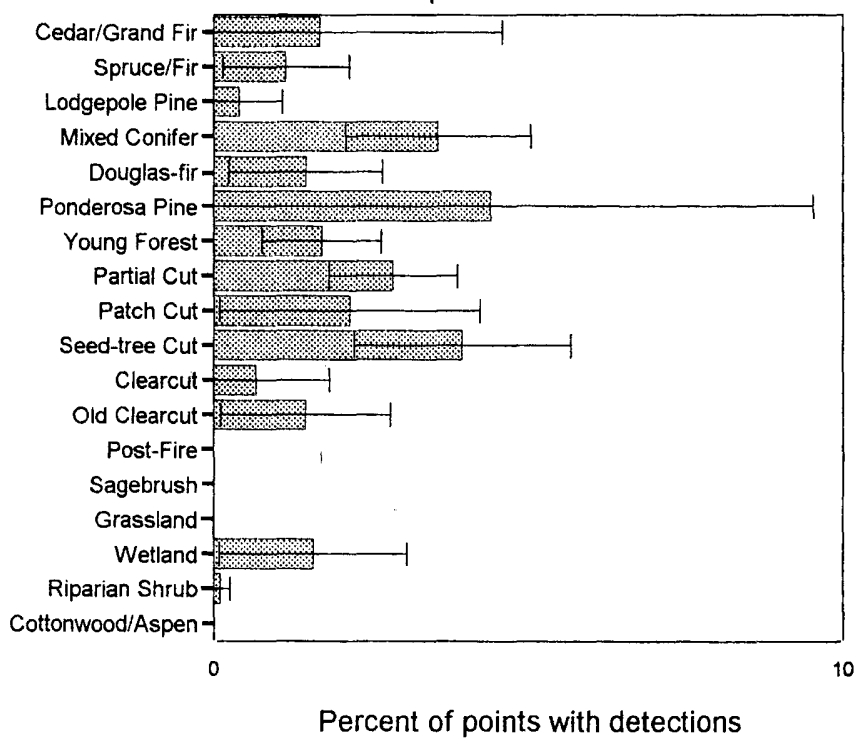


Olive-sided Flycatchers (fig. 23) were detected on 88,62 , and 58 of the points in the 3 years. Considering the naturally occurring cover types, this species was detected most often in Post-Fire stands. It appears to be common in the variously harvested cover types as well. Olive-sided Flycatchers were less frequently detected early in the season, when many harvested stands were surveyed, so their use of harvested stands may actually be more pronounced than indicated here. A graph based on the second half of the season shows little change in relative habitat distribution, although sparse cuts are even more strongly favored. The absence of this species in Ponderosa Pine stands could be due, in part, to this seasonal effect as well as the overall low sample size. A strong increase in detectability of this species as the season progressed resulted in 80 percent of the detections occurring from June 11 onward. However, restricting the data to this period did not change the habitat distribution pattern.

The Olive-sided Flycatcher is one of the species that has declined significantly on western Breeding Bird Survey routes between 1968 and 1991 (Hejl 1994). Given its propensity to use harvested forest types, this is a bit of a mystery unless conditions during winter or migratory passage have deteriorated. Another possibility, however, is that the breeding census data are a misleading indicator of nesting success. In other words, we may be creating an "ecological trap" for the species by cutting in a way that provides only the appearance of an early postfire scene and little else. We need to know whether harvested forest patches are really suitable in terms of reproductive success, or whether they are acting as demographic sinks for this species.

Western Wood-Pewees (fig. 24) were detected on 49 points in all 3 years combined. They occurred mostly in riparian areas, especially Cottonwood/Aspen, as well as open conifer situations such as Ponderosa Pine and Post-Fire forests. Because of their relative abundance in the Post-Fire cover type (a pattern even more pronounced in Hutto, 1995), and their dependence on standing dead trees therein for nest sites, there is a potential negative effect of postfire salvage logging on this species. This is also a species that may be susceptible to excessive cowbird parasitism in the cottonwood bottomland and residential cover types. We need data on nesting success under various riparian management regimes to determine (1) whether cowbird parasitism is a problem or not, and (2) whether such rates depend on the management regime. Although there were only three detections in Ponderosa Pine, the data suggest that this species might benefit from the restoration of lowland old growth ponderosa pine stands.
Figure 23

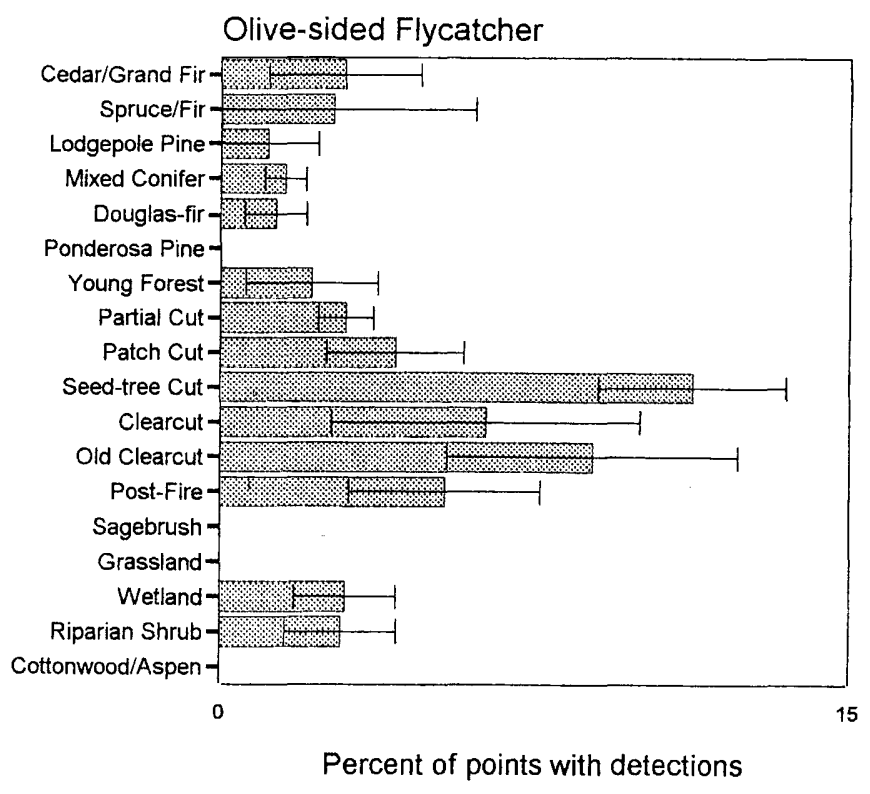

Figure 24

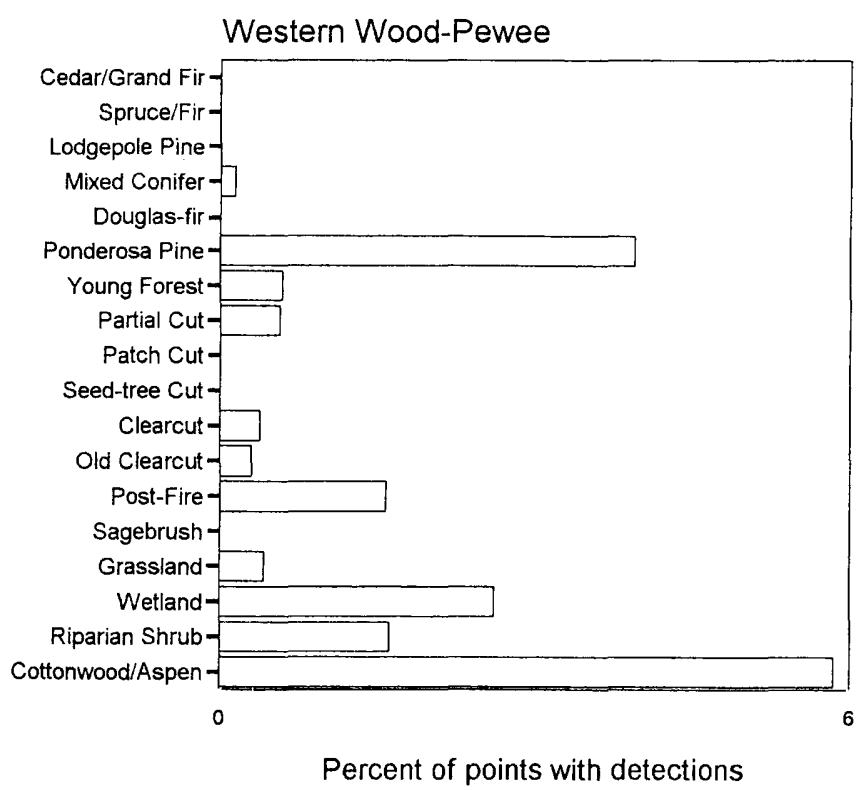


Willow Flycatchers (fig. 25) were detected on 94 points in all 3 years combined, and were strictly tied to riparian areas with adequate shrub cover. Even the rare occurrences in Clearcuts are generally tied to wet microhabitats. The Willow Flycatcher is one of the best examples of a species restricted to riparian areas. Because so little land area consists of this cover type, and because Willow Flycatchers occur in no other cover type, it becomes important to know whether the occurrence and nesting success of this shrub-nesting species varies among the various streamside management practices. In a review of literature on grazing effects in the West (Saab and others 1995), all studies reported a negative impact of cattle grazing on this species, probably because of the associated destruction of vegetation at the flycatcher's preferred foraging and nesting height or because of an associated increase in cowbird parasitism.

Hammond's Flycatchers (fig. 26) were detected on 156,126 , and 104 of the points in the 3 years, most frequently in relatively uncut conifer forests, as well as in riparian areas, which may be closely associated with conifer forests. They were seen more often in cedar-hemlock (11 percent) than in grand fir (4 percent), but the sample sizes were too small to be significant (10 versus 2 detections; Fisher's Exact test, $p=0.26$ ). A decline in detectability of this species as the season progressed resulted in 80 percent of the detections occurring by June 28 . Restricting the data to this period resulted in a small increase in the apparent importance of dry forest types (Douglas-fir and Ponderosa Pine). This species is consistently found to be negatively affected by clearcutting (Hejl and others 1995), and many of the apparent detections in Clearcuts reported here may be misidentified Dusky Flycatchers because the latter species is abundant in clearcuts and these two species are difficult to distinguish in the field.

Hammond's Flycatchers were detected in a somewhat higher percentage of old growth relative to mature conifer forests ( 7.1 percent versus 4.6 percent, $\mathrm{p}=0.057$ ). This biased the results upward for Cedar/ Grand Fir because nine of the twelve detections in that cover type were in old growth. Therefore, within mature forest the species was less likely to be found in Cedar/Grand Fir than in Mixed Conifer, whereas within old growth it was more likely. The numbers were low enough to make conclusions at that level questionable, however. The distribution pattern suggests that we need to retain older, uncut forest patches to provide for the needs of this species. This mirrors the conclusions of Hejl and Woods (1991).
Figure 25

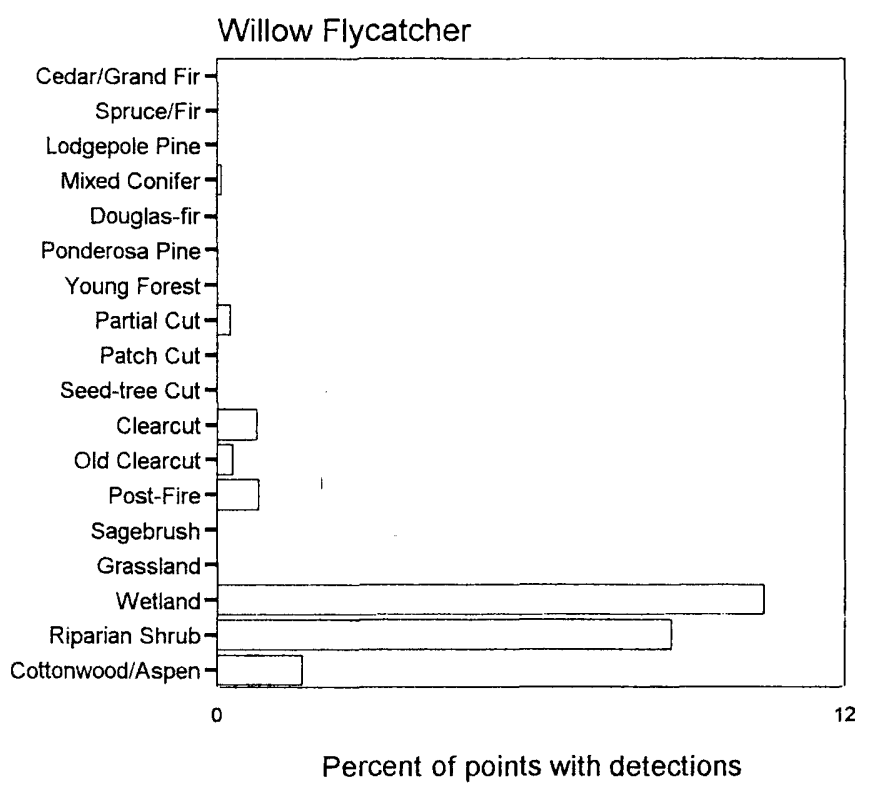

Figure 26

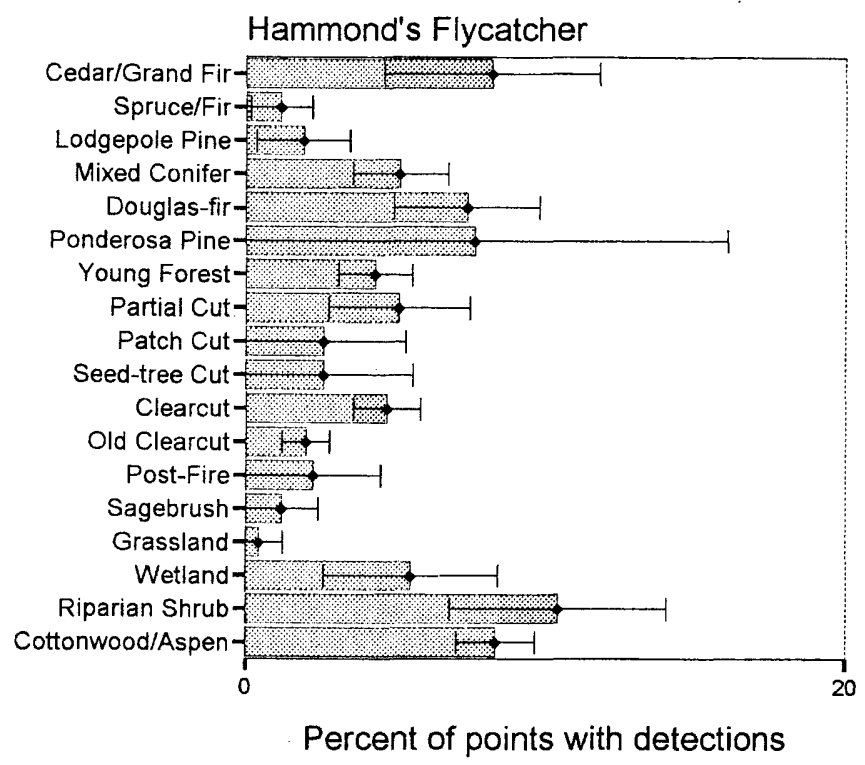

Percent of points with detections 
Dusky Flycatchers (fig. 27) were detected on 317, 245 , and 227 of the points in the 3 years, primarily in riparian areas and early successional forests that contain a good shrub layer. Those habitat conditions are naturally provided in postfire forests, but cut forests seem to provide suitable conditions as well. The high frequency in Ponderosa Pine could in part be due to misidentifications of Hammond's Flycatchers, although the two species may overlap in this cover type, with the Dusky Flycatcher in shrubby microhabitats. They were more likely to be detected in aspen than in cottonwood stands (44 percent versus 23 percent; Fisher's Exact test, $p=0.02$ ). A decline in detectability of this species as the season progressed resulted in 80 percent of the detections occurring by June 26. Part way through the season, both Dusky and Hammond's Flycatcher switch to an alternative partial-song type of call note that makes the two species almost impossible to distinguish. However, restricting the data to the early period did not change the habitat distribution pattern. Although the 30-year (1966 to 1995) population trend data generated from the Breeding Bird Survey do not reveal a significant increase for this species (Peterjohn and others 1996), other analyses suggest that this species is more common now than in the historical past because of forest cutting practices (Sharp 1996). The possibility that we are creating "ecological traps" by pulling them into artificially created situations (cut forests) where they do poorly is unlikely, but certainly possible; the issue merits study.

Cordilleran Flycatchers (fig. 28) were detected on 43 points in all 3 years combined. Except for the Douglas-fir type, they were relatively restricted to riparian bottomlands and adjacent conifer forests. There were nine detections in cottonwood stands (21 percent) and only one in aspen. This species was also more likely to occur in areas with a relatively large number of snags, reflecting an association with the older, denser vegetation types. The species relies heavily on intact riparian corridors, where they nest in cavities (rock pockets) in cut banks ( $R L H$, personal observation). Thus, streambank erosion associated with excessive cattle grazing and streambank alteration due to channelization or stabilization efforts may have a significant negative impact on this species.
Figure 27

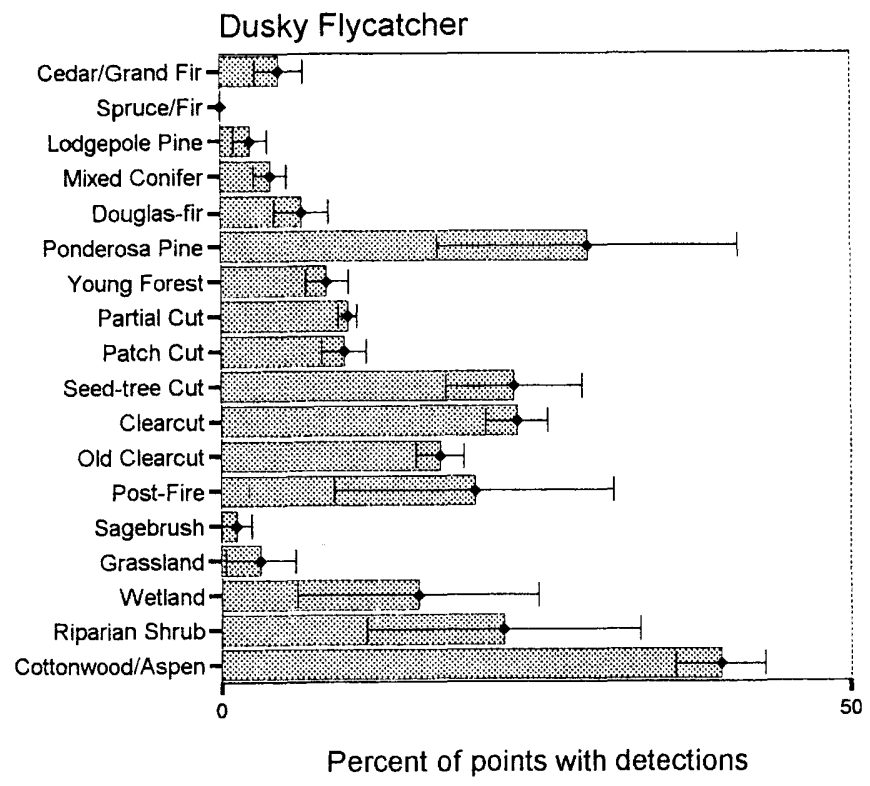

Figure 28

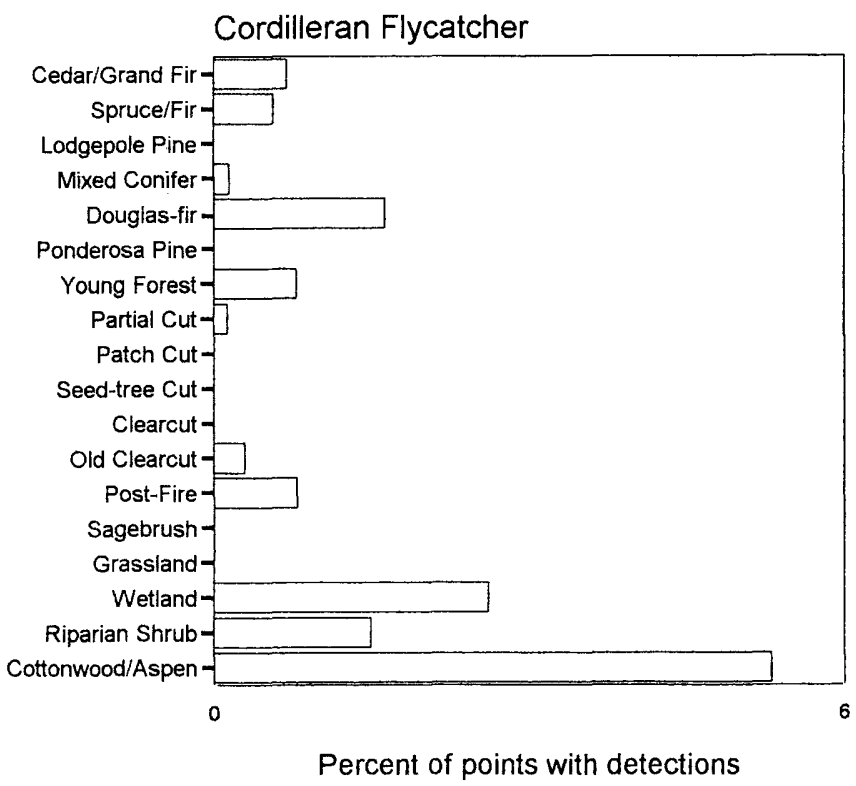


Cassin's Vireos (fig. 29) were detected on 306, 234, and 227 of the points in the 3 years, primarily in the drier coniferous forest cover types. It was more likely to be found in grand fir than in cedar-hemlock (19 percent versus 7 percent; Fisher's Exact test, $p=0.06$ ). Although the Cassin's Vireo is common in the partially cut forest types, its occurrence drops off continuously with increasing levels of tree removal. This is the same pattern exhibited by several common forest bird species, including Red-breasted Nuthatch, Yellow-rumped Warbler, and Western Tanager, and it implies a certain degree of dependence on the retention of a significant density of trees.

Restriction of the data to points west of the Continental Divide (fig. 30), where the species was over seven times as likely to be detected, increased the apparent use of Ponderosa Pine and Douglas-fir by this species. However, restriction of data to the period through June 28 (including 80 percent of the detections) resulted in a decrease in the apparent use of Ponderosa Pine and an increase in detection probability in Cedar/Grand Fir and mixed-conifer stands. The small sample size and large error bars in Ponderosa Pine make these conclusions questionable, however. In our experience outside formal surveys, Cassin's Vireos are common in ponderosa pine. In fact, within the mixed-conifer cover type (1994 only), they were much more likely to be detected (38 percent versus 17 percent) when at least some ponderosa pine was present in the canopy layer (but the presence of cedar or grand fir made no difference). We need to find out if pure stands of ponderosa pine are less suitable or if some other factor is contributing to the variability.
Figure 29

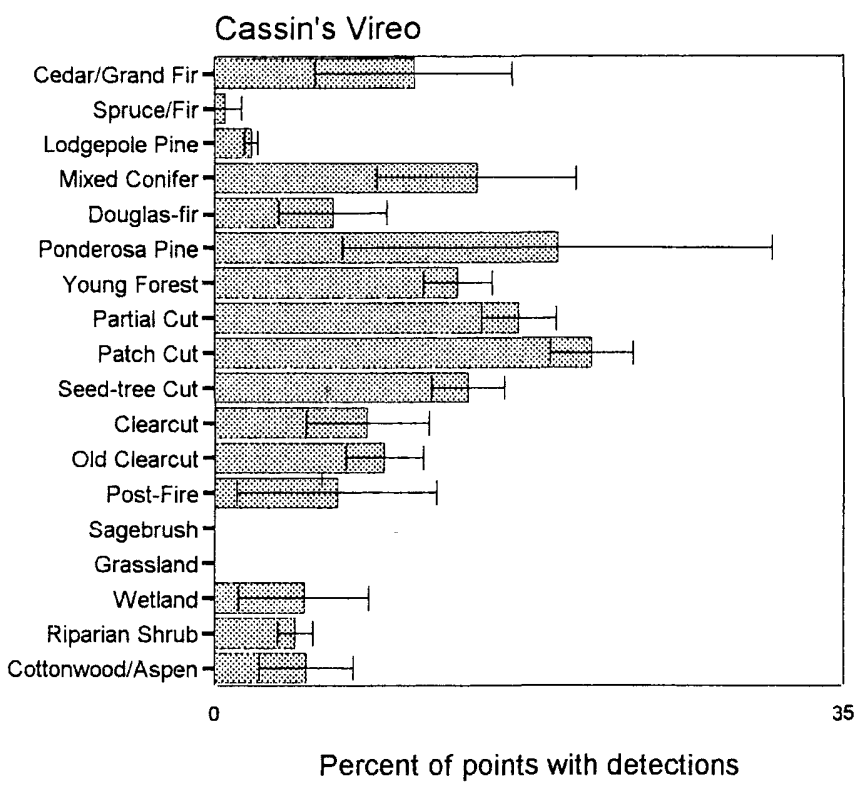

Figure 30

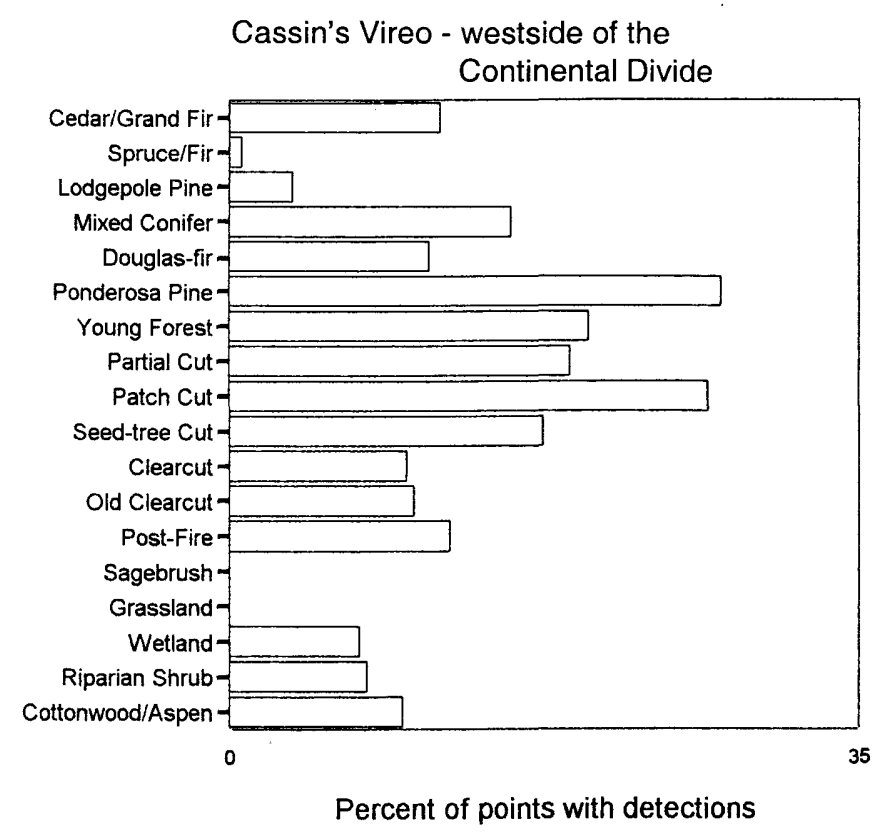


Warbling Vireos (fig. 31) were detected on 387, 382 , and 348 of the points in the 3 years. Warbling Vireos were frequently detected in both riparian and harvested forest cover types. In nonriparian cover types, they are strongly associated with deciduous shrubs; this explains their high probability of detection in cut coniferous forests, where there is an early successional "release" of shrub vegetation after timber harvesting. They may also be drawn into other conifer cover types by roadside vegetation. The abundance of this species in the cut forest types would make it appear to be in good shape because of the abundance of those cover types across the landscape. Nonetheless, this is another species that could be drawn into those artificially created forests and then not do well; we need data to test whether the cut forests are acting as "ecological traps." This is especially important because of the high vulnerability of this species to cowbird parasitism (Tewksbury and others 1998). Warbling Vireos are known to be especially common in aspen stands, and this is indicated in these data as well. They were twice as likely to be detected in aspen than in cottonwood stands (66 percent versus 33 percent; Fisher's Exact test, $\mathrm{p}<0.001)$.

Red-eyed Vireos (fig. 32) were detected on 46 points in all 3 years combined, primarily in the riparian cover types. In our experience outside of this study, this species is entirely restricted to cottonwood bottomland forests, and the data are at least partially consistent with this impression. There were five detections in cottonwood stands and none in aspen. The minor occurrences in a few cut forest types reflect either misidentifications or the fact that large deciduous trees are sometimes left after a harvest. The abundances in Wetland and Riparian Shrub types are likely to be artifacts of the presence of nearby cottonwood stands. Because of its near restriction to a forest cover type that is rare on the landscape, it becomes critical to ensure that the species is doing well there. The management issue of primary concern is the high cowbird parasitism rates associated with excessive cattle grazing in most riparian bottomlands.
Figure 31

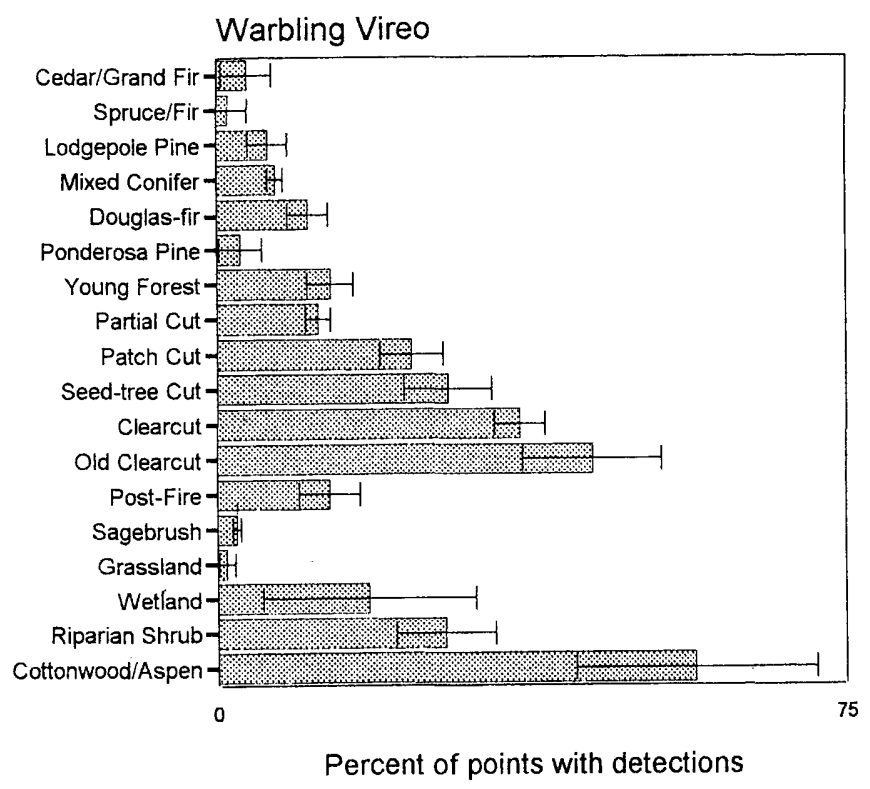

Figure 32

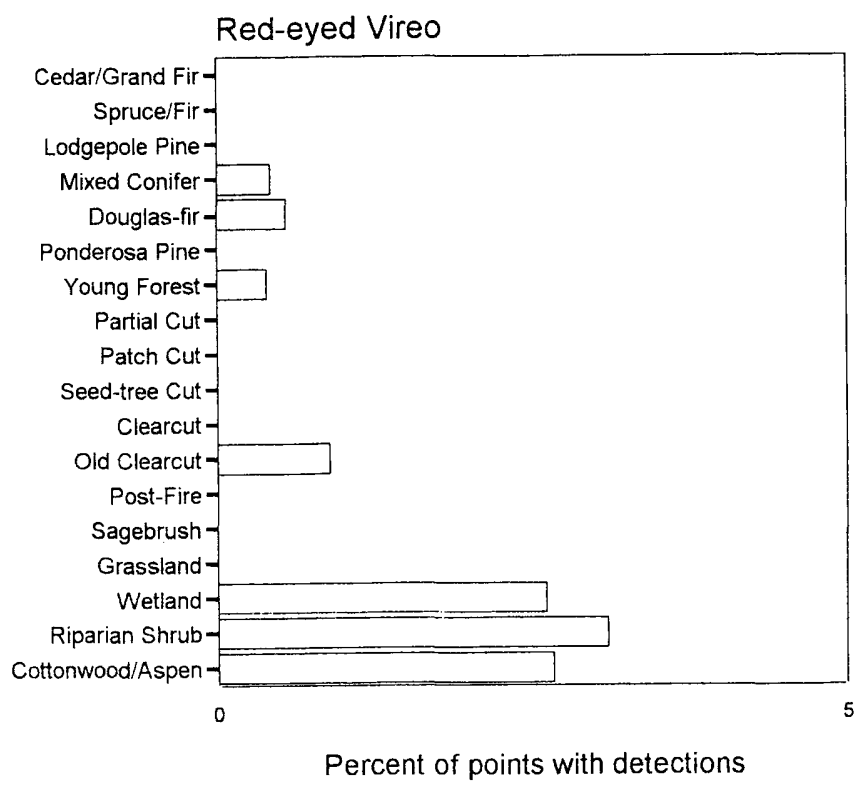


Gray Jays (fig. 33) were detected on 150, 114, and 122 of the points in the 3 years. They were found in a wide variety of conifer forest types, but most often in the higher elevation, uncut conifer forests with Spruce/ Fir or Lodgepole Pine. If this wide-ranging species uses harvested forests for foraging and egg predation, it may be a big reason why nest success of other songbirds might not mirror their relative abundance in harvested forests.
Figure 33

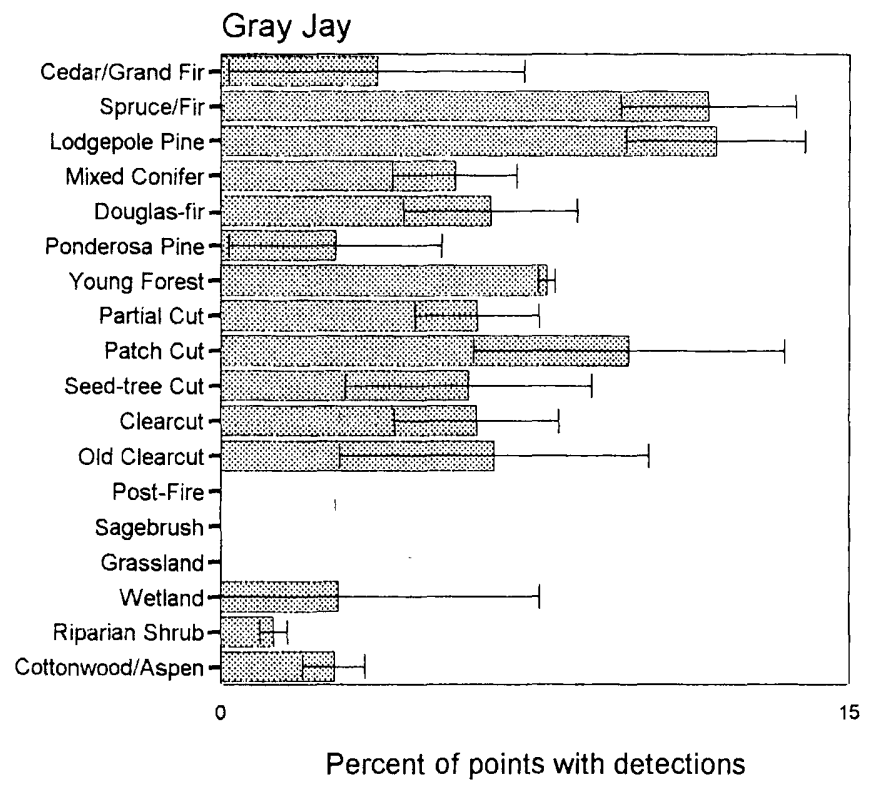

Figure 34

Steller's Jays (fig. 34) were detected on 74,43 , and 53 of the points in the 3 years. They were found in most conifer forest types, but were most frequent in the harvested cover types. Among uncut forest stands, they were detected in a somewhat higher percentage of old growth relative to mature conifer forests (3.0 percent versus 1.3 percent, $p=0.03$ ). This is consistent with a preference for more open forest (as is the near absence in Lodgepole Pine and Young Forest), although we need more data to explore this further. Although only 11 detections occurred east of the Continental Divide, restricting the data to westside points did not change the habitat distribution results appreciably. This wide-ranging species may use harvested forests for foraging (egg predation?) rather than nesting activity. If so, this species may be a big reason why nest success of other songbirds might not mirror their relative abundance in harvested forests. The relative abundance of this species and other corvids in harvested forests underscores the need for nest success studies therein. 
Clark's Nutcrackers (fig. 35) were detected on 109,63 , and 62 of the points in the 3 years, and they were distributed broadly across the conifer forest cover types, although absent from Cedar/Grand Fir. These results may be deceiving because the "nomadic" nature of this species makes it tough to use pointcount detections to draw inferences about patterns of habitat use. Also, we had few points in the subalpine, whitebark pine forests known to be used by this species. However, the use of Douglas-fir and especially Ponderosa Pine forests is supported by the literature (Tomback 1998). The occurrence of this species may be closely linked to areas of high conifer seed production, including early postfire habitat (Hutto 1995), so this may be another species that is negatively affected by postfire salvage cutting.

Common Ravens (fig. 36) were detected on 62, 34 , and 40 of the points in the 3 years. Although they occur in open country areas with sagebrush and ranching activity, this species is most frequently detected in coniferous forests of all types. A decline in detectability of this species as the season progressed resulted in 80 percent of the detections occurring by June 27. However, restricting the data to this period did not change the habitat distribution pattern. The wide-ranging nature of this species makes it difficult to determine specific habitat needs, but they commonly use large trees for nesting, so they are probably benefitted by the occurrence of old growth in the landscape. Ravens are notable egg predators, and whether their effect on open cup-nesting bird species is more pronounced in harvested forests is unknown. The abundance data alone do not suggest any special problem associated with forest harvesting practices.
Figure 35

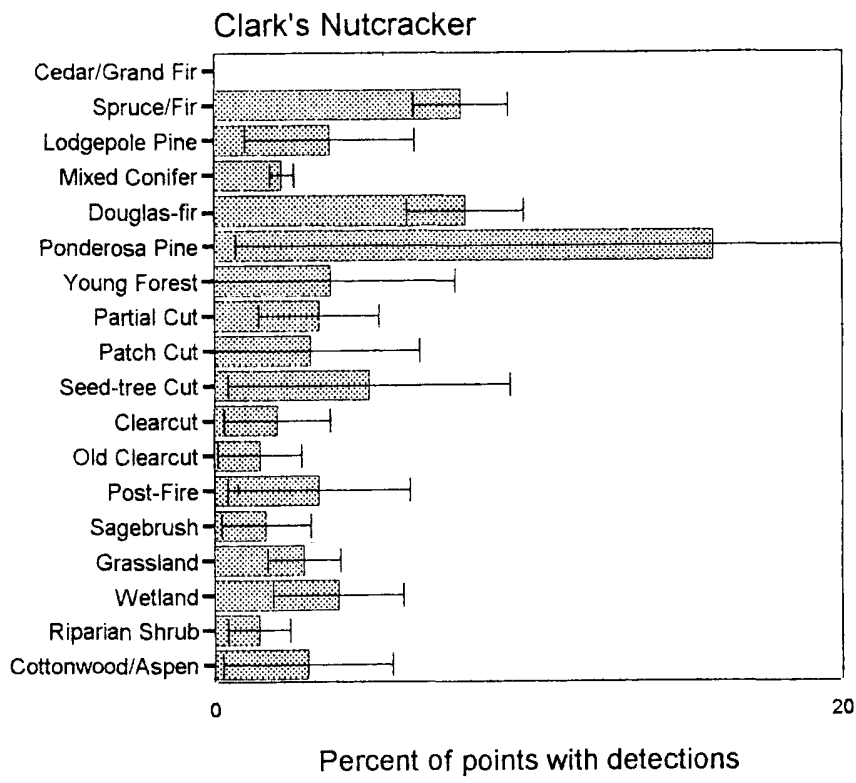

Figure 36

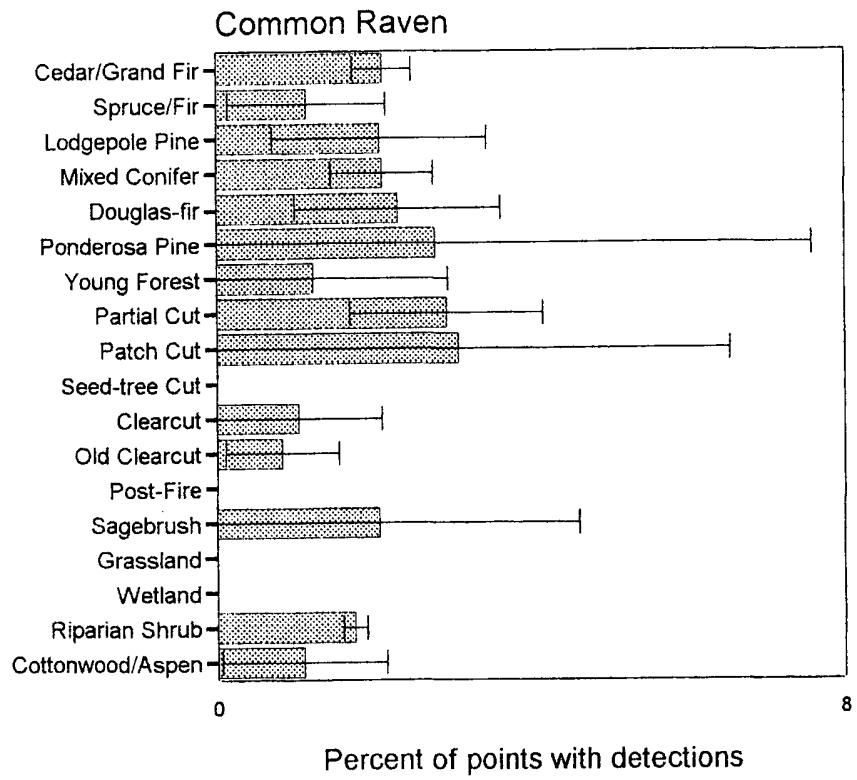


Horned Larks (fig. 37) were detected on 77 points in all 3 years combined, but were restricted to Grassland and Sagebrush (as well as agricultural areas, from counts not otherwise reported here). Because of the relative restriction of this species to the cover types that are most heavily influenced by cattle grazing, we need information on the nesting success of this species in relatively grazed and relatively ungrazed situations. However, we do not anticipate any problems, because this species prefers bare ground or grasses less than a few centimeters high (Wiens and others 1987), and achieves the highest population densities in areas with the most bare ground. This species has been universally positive in its response to grazing (Saab and others 1995).

Tree Swallows (fig. 38) were detected on 106 points in all 3 years combined, primarily in riparian bottomlands, wetlands, and some open country situations, although the latter may be an artifact of the proximity of artificial roadside nest boxes. Many harvested forest stands will attract Tree Swallows if snags remain. A study involving postfire stands found this species to be detected more frequently in that cover type than we found here (Hutto 1995). If the Postfire and Cottonwood/Aspen cover types are especially important to naturally occurring populations, then the loss of nest trees in postfire salvage sales may be detrimental, and the presence of nest-usurping European Starlings in the bottomlands may also pose a special threat to this swallow species.
Figure 37

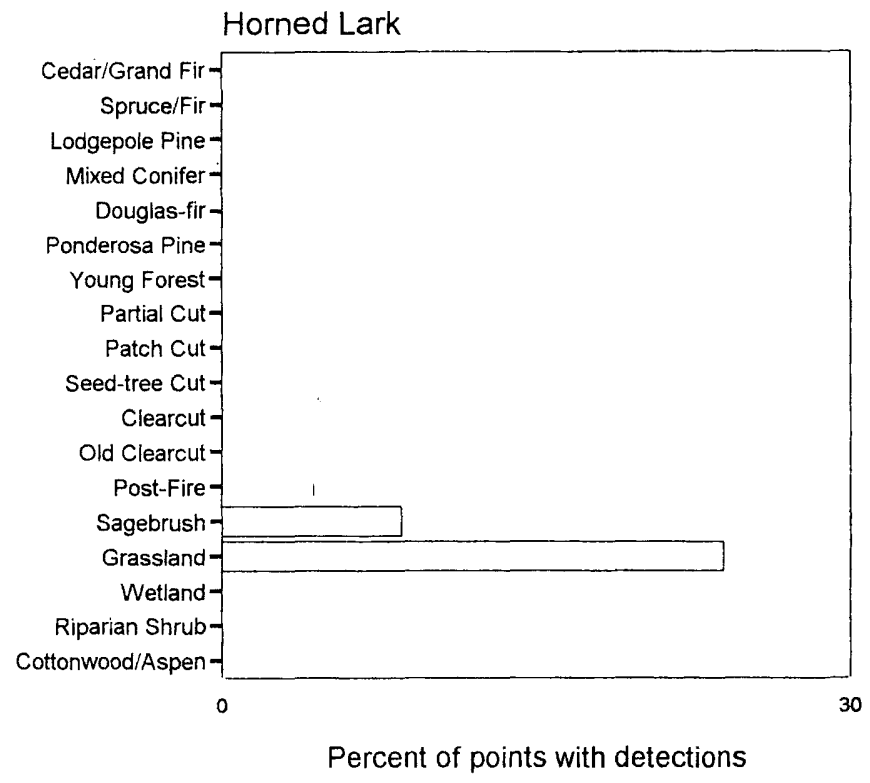

Figure 38

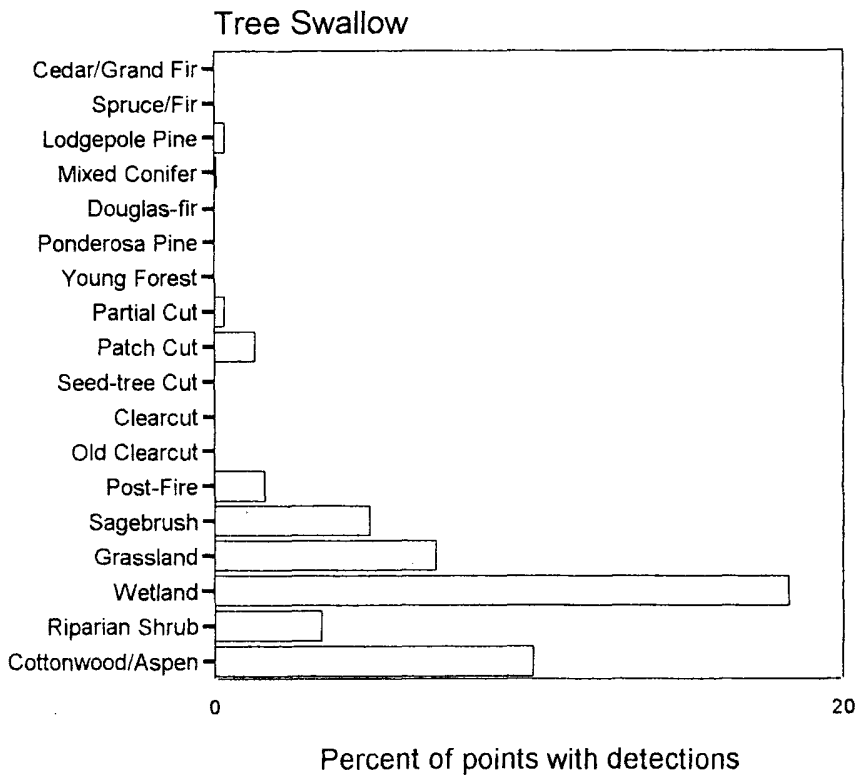


Violet-green Swallows (fig. 39) were detected on only 31 points in all 3 years combined. Under natural conditions, this species may be fairly restricted to riparian bottomland conditions. The eight detections in Sagebrush may be due to the proximity of riparian areas or roads with nest boxes, although this species does occur in more remote sagebrush country. Further study may be of interest. The management issue of primary concern is whether the presence or reproductive success of naturally occurring populations of this species are affected negatively by various riparian land-use practices.
Figure 39

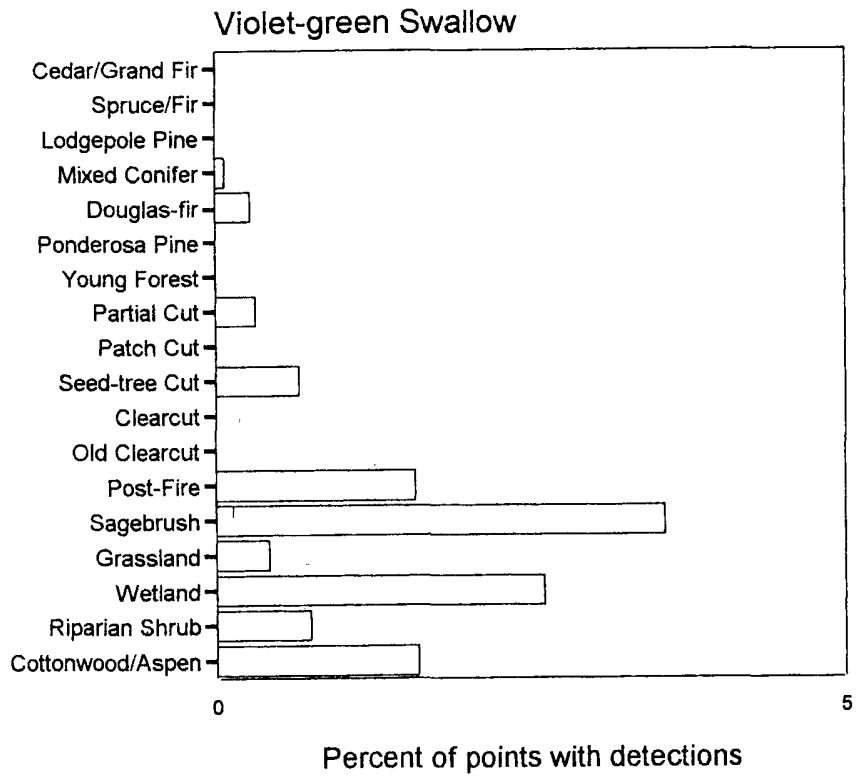


Black-capped Chickadees (fig. 40) were detected on 94,124 , and 120 of the points in the 3 years. Of the three chickadee species in the region, this one is relatively common in riparian cover types, as well as in conifer forests with riparian stringers or early successional vegetation. Although Black-capped Chickadees do occur east of the Continental Divide (Montana Bird Distribution Committee 1996), we had only 21 detections there, and the species was seven times more likely to be detected at points on the westside. Restriction of data to the west (fig. 41) better showed the expected importance of riparian areas to this species. The apparent usage of pine forests is interesting but would need to be confirmed. Many detections in the conifer forest types may represent misidentifications by observers who were willing to identify the species on the basis of song alone-a song that is similar to that of the Mountain Chickadee. However, Black-capped Chickadees do use many open conifer and harvested cover types when deciduous elements are present. Deciduous vegetation may occur along roadsides, so this species may be drawn into conifer cover types by the presence of roads. We need to learn whether this leads to successful reproduction in these areas, and how this species is affected "best management practices" in the riparian areas where it is known to breed. The species also depends on snags, especially rotting stumps. Thus, excessive woodcutting in riparian areas may be a concern as well.
Figure 40

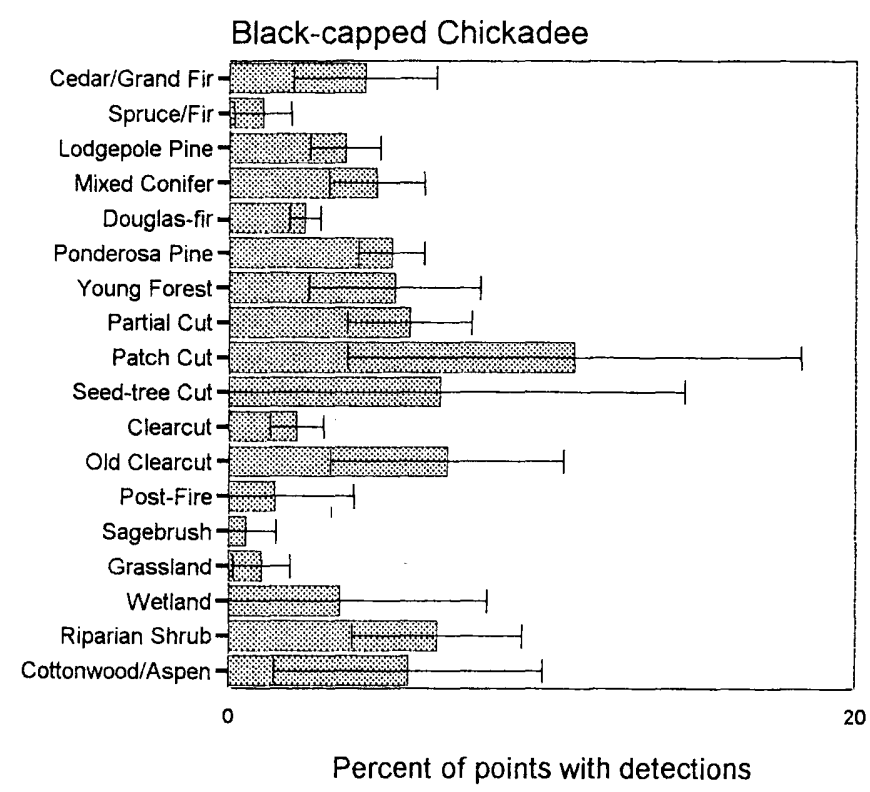

Figure 41

Black-capped Chickadee - westside of the Continental Divide

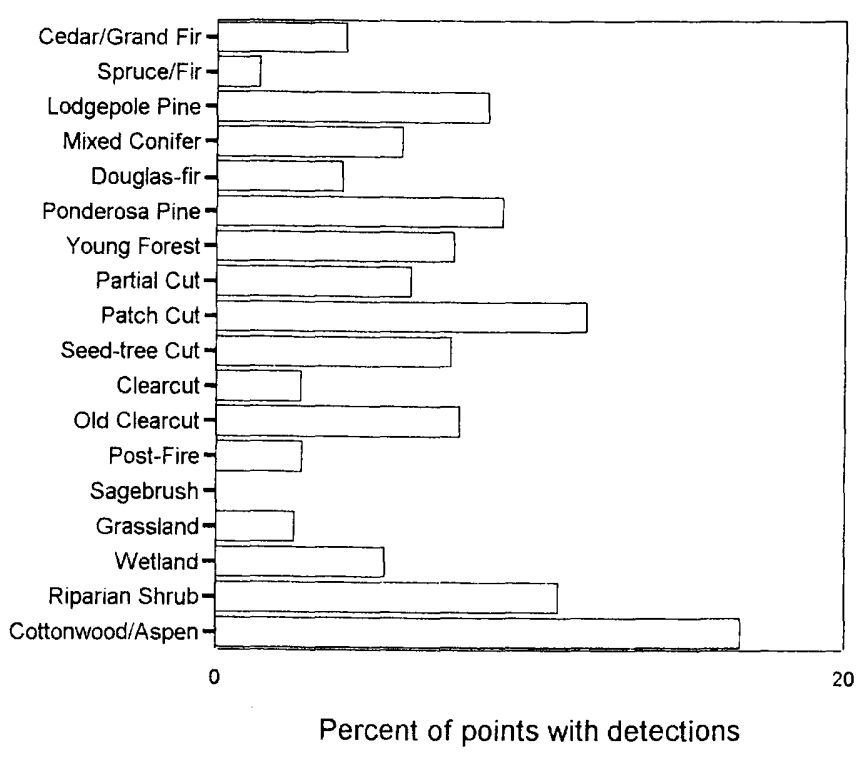


Mountain Chickadees (fig. 42) were detected on 437,477 , and 376 of the points in the 3 years. This species is a cavity nester that often uses rotting stumps as nest sites. This species is most common in the coniferous forest types, and it appears to be somewhat less common in harvested forest types, as has been found in other timber harvesting studies (Hejl and others 1995). It was also common in Young Forest, and it was detected in a lower percentage of old growth relative to mature conifer forests (11.6 percent versus 19.1 percent, $p=0.001$ ). Nine of 10 detections in the Cedar/Grand Fir cover type were in cedar/hemlock. Although primarily a coniferous forest species they were abundant in or near aspen stands (30 percent versus only 7 percent in cottonwood), so aspen may enhance the worth of a conifer forest for this species. The Mountain Chickadee requires snags for nesting and is negatively affected by clearcutting, but otherwise seems to be a generalist species of little management concern.
Figure 42

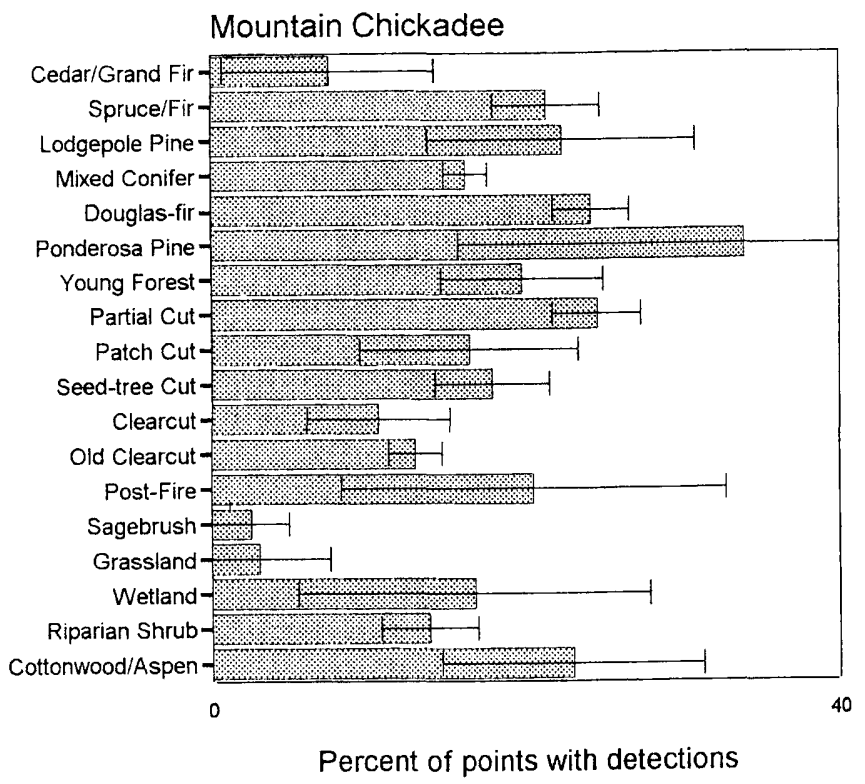


Chestnut-backed Chickadees (fig. 43) were detected on 102,85 , and 109 of the points in the 3 years. This species is clearly associated with Cedar/Grand Fir forests, a type largely avoided by the Mountain Chickadee. The species used grand fir as often as cedar/hemlock (Fisher's Exact test, $p=0.80$ ), and a large proportion of the mixed-conifer and harvested forest stands where this species occurred also had a major component of cedar, hemlock, or grand fir. This species also appeared to occur predominantly in relatively intact forest. This species is largely restricted in geographic distribution to northern Idaho and far northwestern Montana. Restriction of the data to west of the Continental Divide, or even to just the Kootenai National Forest and Idaho, did not change the pattern of habitat distribution, however, probably because Cedar/Grand Fir was also restricted to the western areas. The detectability of this species declined as the season progressed, resulting in 80 percent of the detections occurring by June 28 . When the data were restricted to this period, the detection probability of Mixed Conifer became equal to Cedar/ Grand Fir. When both restrictions were applied simultaneously (fig. 44), the probability of detection was highest in Mixed Conifer ( the percentage within Spruce/Fir also increased, but represented only four detections).
Figure 43

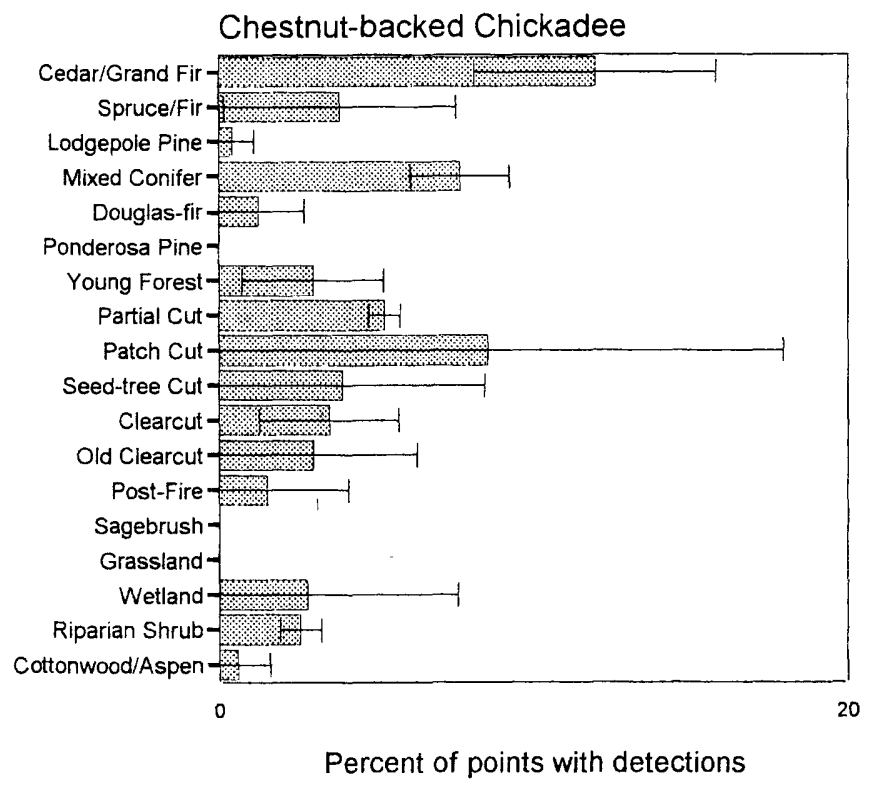

Figure 44

Chestnut-backed Chickadee - to June 28, westside of the Continental Divide

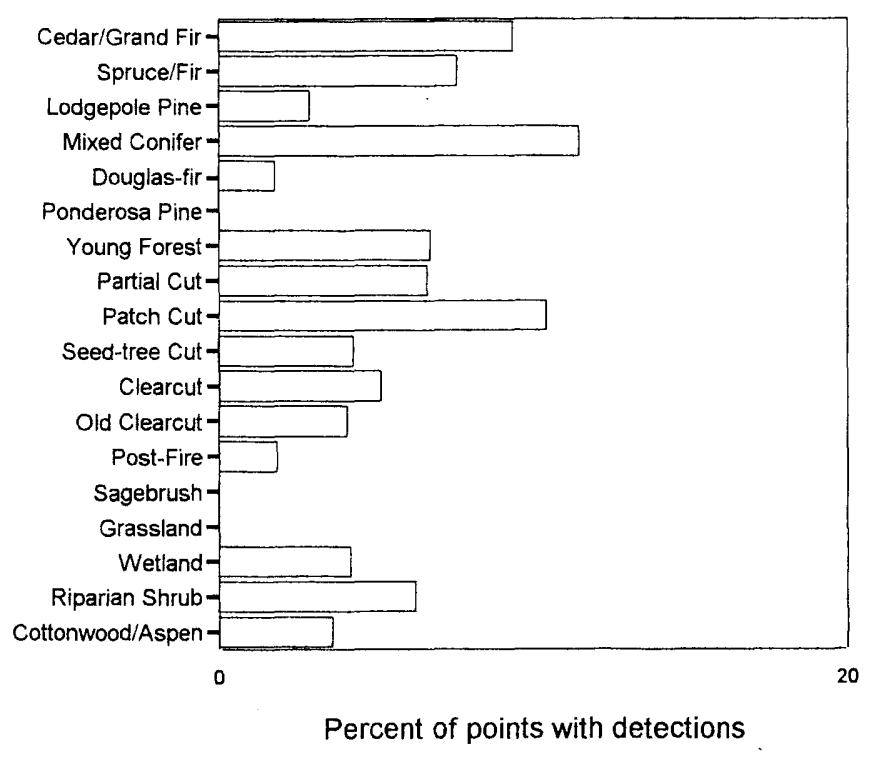


Red-breasted Nuthatches (fig. 45) were detected on 994,805 , and 772 of the points in the 3 years. This is one of the most common species throughout the conifer forests of the Northern Rockies, and it was especially common in the lower-elevation forest types. It was also detected in a higher percentage of old growth relative to mature conifer forests $(52.5$ percent versus 45.3 percent, $p=0.014$ ). Although Red-breasted Nuthatches also occurred commonly in cut forest types, it is clear that their probability of occurrence decreased steadily with increasing amounts of timber removed. In fact, this is one species that has been shown through literature review to be consistently less abundant in harvested than unharvested Rocky Mountain forests (Hejl and others 1995, Hutto and others 1993). Were it not for its widespread occurrence across most of the relatively uncut conifer forest types, this would be a more serious management concern.

White-breasted Nuthatches (fig. 46) were detected on only 62 points in all 3 years combined. The habitat distribution graph for this species may be misleading because, in our experience outside of formal surveys, White-breasted Nuthatches are most common in ponderosa pine forests and in cottonwood bottomland forests with the pine element present. It is uncertain why they were detected in neither of those cover types, except that those cover types were not well represented in our sample. Because 38 of the 62 detections (on 25 of 45 transects) of this species were in Idaho (where only 31 percent of the sample points occurred), it may be that Montana is more on the periphery of their range, or simply that their preferred habitat was more commonly sampled in Idaho. The relative abundance in Cedar/Grand Fir was based on only two detections. The relative abundance in PostFire (based on only three detections) is inconsistent with results from a study (Hutto 1995) based on over 600 points in burned forests, in which no Whitebreasted Nuthatches were found.

The biology of White-breasted Nuthatches suggests that they may need relatively large trees in the areas where they occur (McEllin 1979). Thus, the management issue of primary concern is one of determining which silvicultural methods used in ponderosa pine forests are most compatible with their needs.
Figure 45

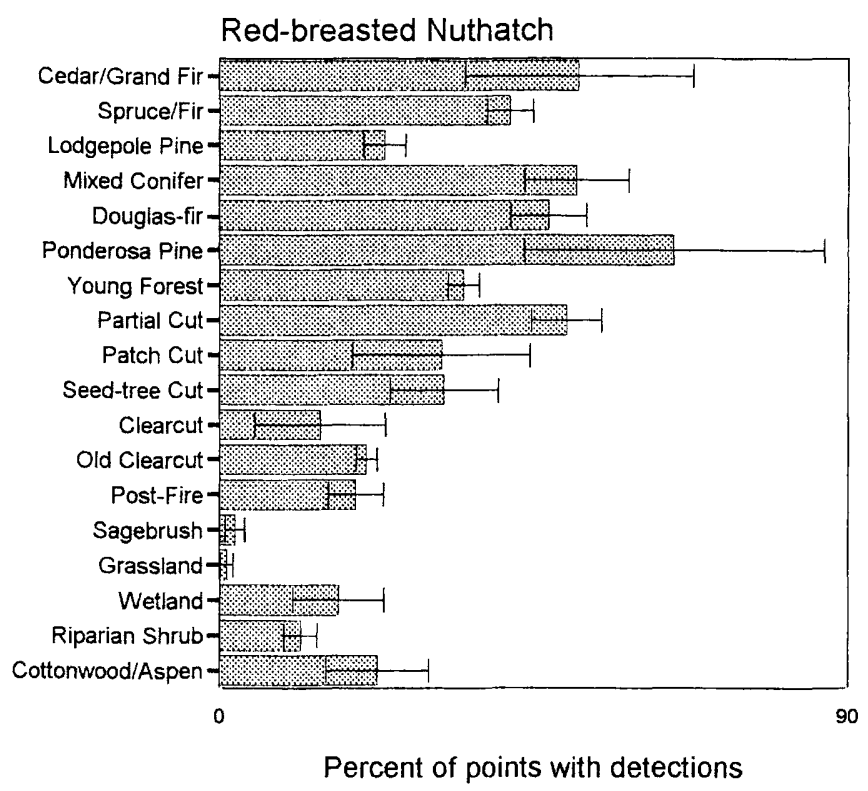

Figure 46

White-breasted Nuthatch

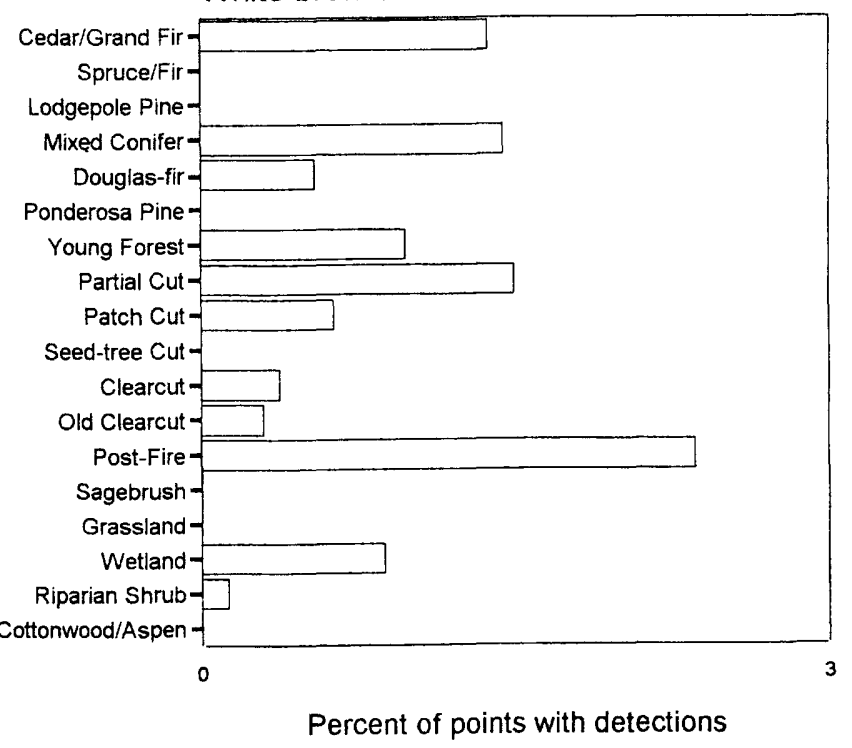


Brown Creepers (fig. 47) are uncommon birds of dense, mesic coniferous forests in the western part of the region. They were detected on only 34,43 , and 62 of the points in the 3 years. This species was most common in Cedar/Grand Fir, and less so in other uncut coniferous forests types that may produce dense stands when old. It was seen more often in cedarhemlock ( 13 percent) than in grand fir ( 6 percent), but the sample sizes were too small to be significant (12 versus 3 detections; Fisher's Exact test, $\mathrm{p}=0.26$ ). Brown Creepers were mostly absent from logged or nonconiferous cover types. A recent literature synthesis (Hejl and others 1995) also revealed that every study on the effects of timber harvesting in the Rocky Mountains has found creepers to be less abundant in harvested than unharvested forest types.

Brown Creepers were much more likely to be detected in old growth than in mature forest (8.6 percent versus 3.1 percent, $p<0.001)$. This agrees with other studies (for example, Mannan and Meslow 1984). The distribution of creepers within mature forest was similar to that shown in figure 47, with Cedar/ Grand Fir greatly favored. When we restricted the data to old growth, a somewhat different picture emerged (fig. 48), and other cover types were used nearly as much Cedar/Grand Fir. This suggests the possibility that Brown Creepers use either old growth or cedar-hemlock, and that both criteria may not be necessary, but the sample sizes were too low to make any conclusions (a total of only 26 detections are represented in fig. 48). The maintenance of old growth conifer forest is probably important to this species in most areas, and fragmentation of old growth habitat may have negative consequences (Hejl and Paige 1994).

There were not enough detections of this species for subsets of the data to be analyzed separately for examining other potential biases either. For example, creepers were not consistently detected across the sampling season; there was a tendency in all years for more individuals to be detected later in the season. Overall, twice as many creepers were detected in the second half of the season as the first (93 versus 46 ). This may have biased some probability estimates for cover types that were unevenly sampled through time. In particular, the probability of occurrence in Spruce/Fir may be lower, and that in Ponderosa Pine may be higher, than the data suggest. Cedar/Grand Fir tended to be more common in the second half of the season as well, but this was probably not strong enough a bias to negate the obvious high usage of this cover type by creepers.

As with most species, the average distance to detection was higher in Cedar/Grand Fir (fig. 6a), so there was no evidence that creepers were harder to detect there. In fact, creepers were detected most often in dense forest, where average detectability was expected to be less. Therefore, if there were any bias, there would be an even greater relative occurrence in uncut relative to cut forest cover types than was demonstrated here.
Figure 47

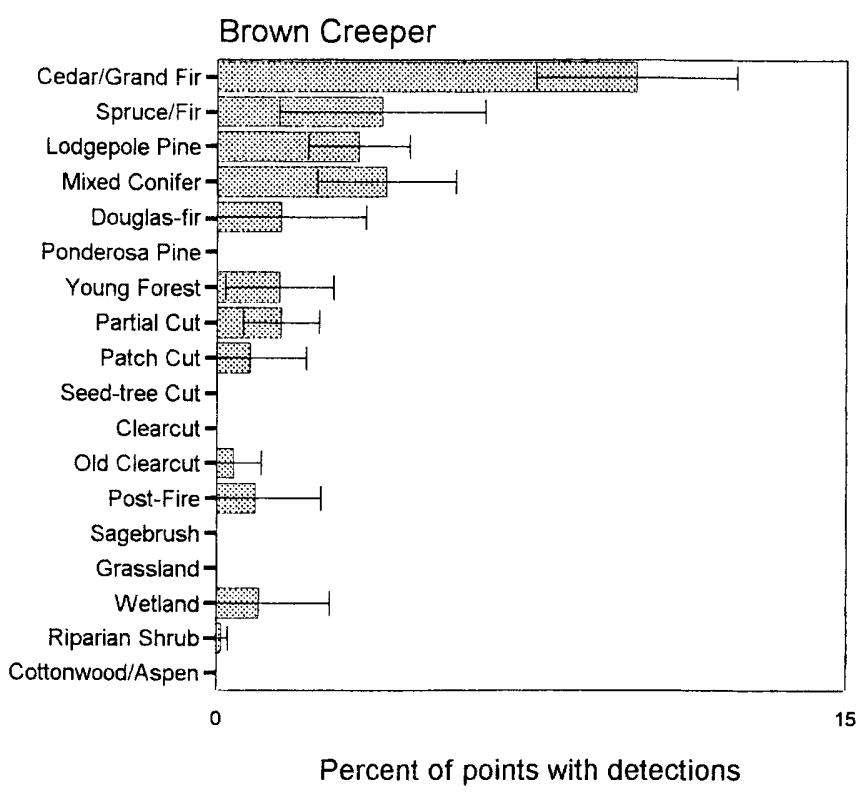

Figure 48

Brown Creeper - old growth only

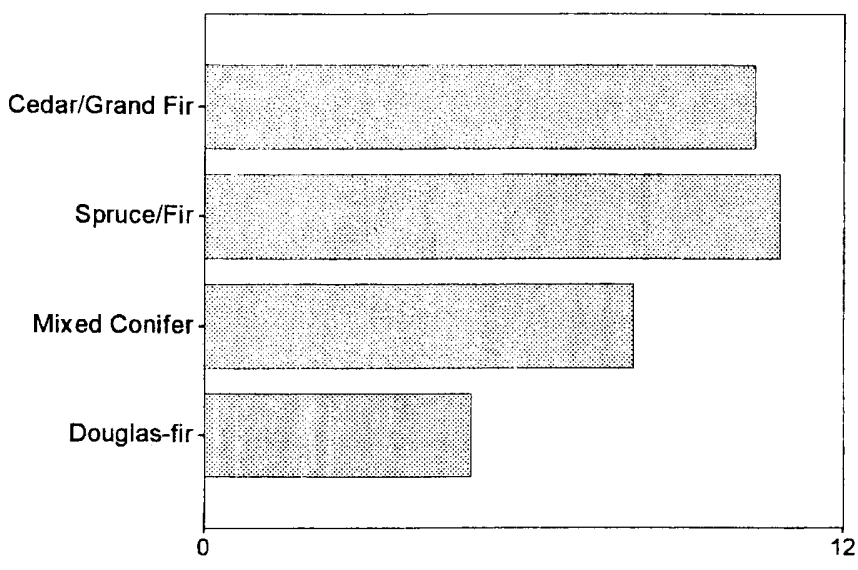

Percent of points with detections 
Rock Wrens (fig. 49) were detected on 51 points in all 3 years combined, especially in open Sagebrush, Grasslands, and even Post-Fire forests. This is a species of open habitats with rock outcrops or boulderstrewn slopes, a known microhabitat requirement that is not reflected in our data here. This is a good example of an uncommon, specialist species that is not well sampled by the broad-scale design of this study.
House Wrens (fig. 50) were detected on 60, 48, and 33 of the points in the 3 years, primarily in riparian cover types and in a variety of cut and Post-Fire conifer forest types. They were detected more often in aspen than in cottonwood stands, although the sample sizes were too low to draw conclusions (18 versus 4 detections; Fisher's Exact test, $p=0.79$ ). Although riparian lands may be the primary habitat of this species under natural conditions, the land area covered by cut forests is substantially greater. Thus, if cut forests are acting as "ecological traps" by having the appropriate superficial characteristics but being otherwise unsuitable, there is potential for a negative impact of cutting on this species. There is also the issue of nest usurpation by European Starlings in the bottomlands themselves. Finally, House Wrens are susceptible to nest-site loss from salvage cutting postfire forests. Indeed, in one study (Hitchcox 1996), House Wrens were three times less abundant in salvage-logged plots, but their nest success was no different.

A strong decline in detectability of this species as the season progressed resulted in 80 percent of the detections occurring by June 21 . Restricting the data to this period resulted in minor changes to the habitat distribution pattern that could be due to sampling error, including an even greater apparent use of Clearcuts. House Wrens are not known to occur in higher elevation forests, so it is unlikely that their absence there in this study was a misleading result of the lateseason sampling bias of higher elevation forests.
Figure 49

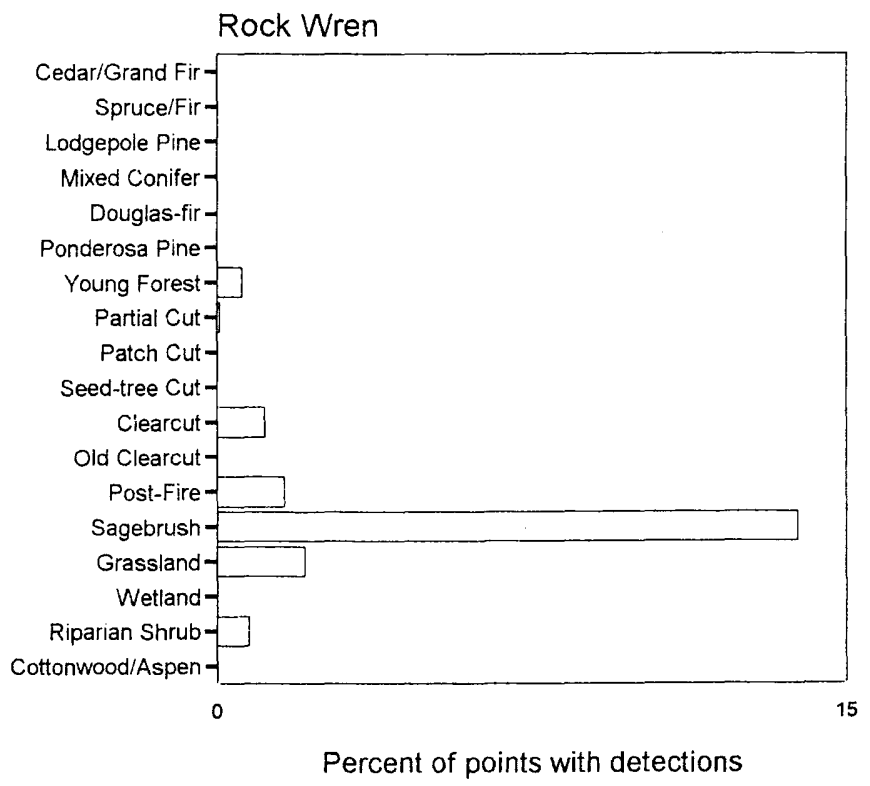

Figure 50

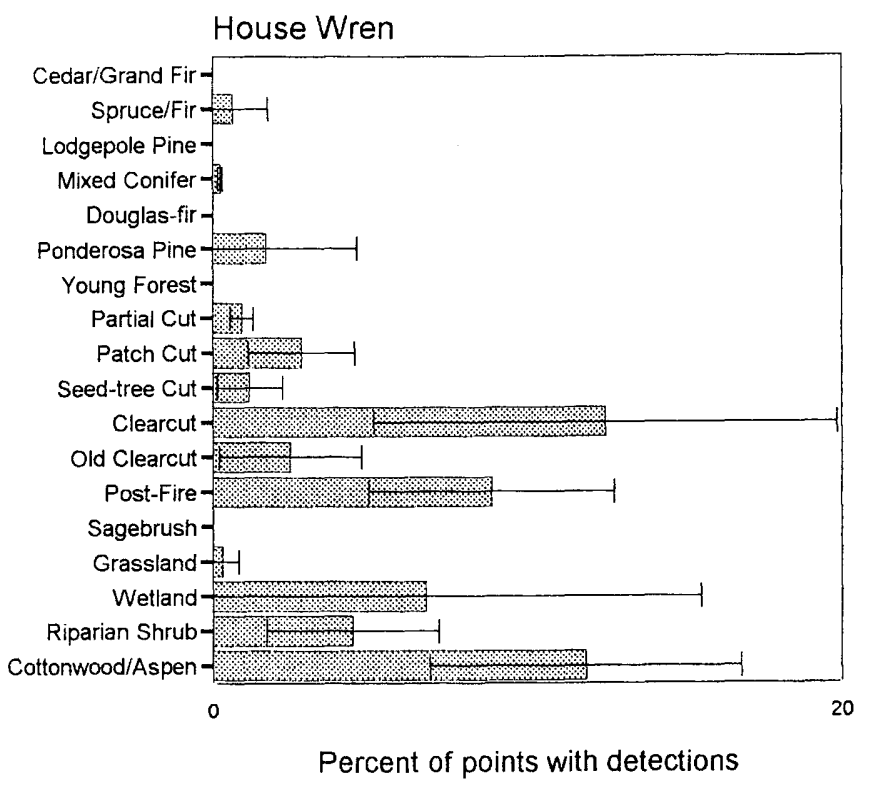


Winter Wrens (fig. 51) were detected in the westernmost portion of the region on 137,196 , and 164 of the points in the 3 years. They were relatively restricted to uncut forest types, especially Cedar/ Grand Fir and Spruce/Fir. When the Cedar/Grand Fir category was split into separate components, Winter Wrens were shown to be twice as common in cedar/ hemlock (40.4 percent) than in grand fir (19.2 percent) or spruce/fir (21.7 percent). The dramatic decrease in probability of detection with even moderate levels of forest cutting was also striking.

The Winter Wren and the Brown Creeper were the only species that were more than twice as likely to be detected in old growth than in mature forests (21 percent versus 9 percent for the wren, $p<0.001$ ). This was not due to the large number of old growth points in Cedar/Grand Fir. Within Cedar/Grand Fir, wrens were still more than twice as likely to use old growth as mature forest ( 62 percent versus 23 percent). Also, within old growth, cedar/hemlock was still more strongly used than any other type (fig. 52a), including grand fir. Within mature forest only, however, cedar/ hemlock, grand fir, and spruce/fir were used to approximately the same degree (fig. 52b), suggesting it may be the old growth features that make cedarhemlock particularly useful to this species. These results imply that Winter Wrens need uncut, old growth forest to meet their habitat needs. Forest fragmentation may also have negative consequences (Hejl and Paige 1994).

Of 497 detections of Winter Wrens over 3 years, only four occurred east of the Continental Divide. This is the eastern edge of their range in Montana, as confirmed by long-term distribution records (Montana Bird Distribution Committee 1996). It is not known whether this distribution is due only to cover type availability or to some independent climatic factor. When the analyses were redone with data restricted to west of the Divide, the same pattern resulted, although the association with riparian cover types was more apparent (fig. 53).

The association with streamside riparian conditions was even more apparent when the 1994 data set was compared to the other points in 1994 that had riparian cover within $100 \mathrm{~m}$ (otherwise excluded in this report). Winter Wrens were detected on 26 percent of points with riparian edge nearby, compared to only 6 percent of points with no edge. Because of this strong association, this species may serve as a good indicator of the suitability of alternative streamside management practices for wildlife populations.
Figure 51

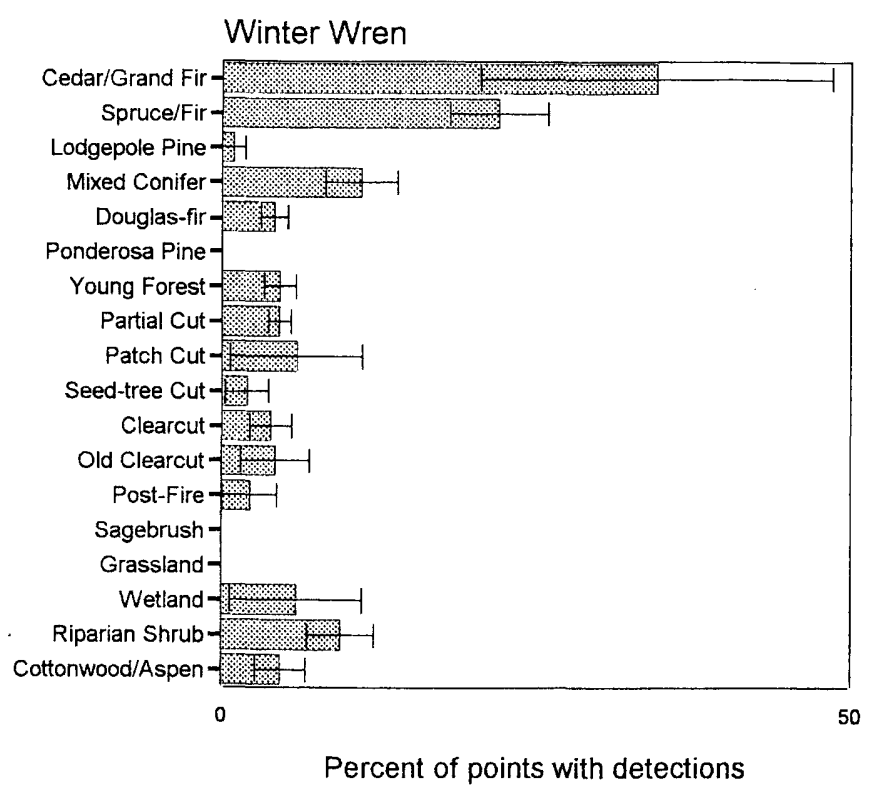


Figure 52

a. Winter Wren - old growth only

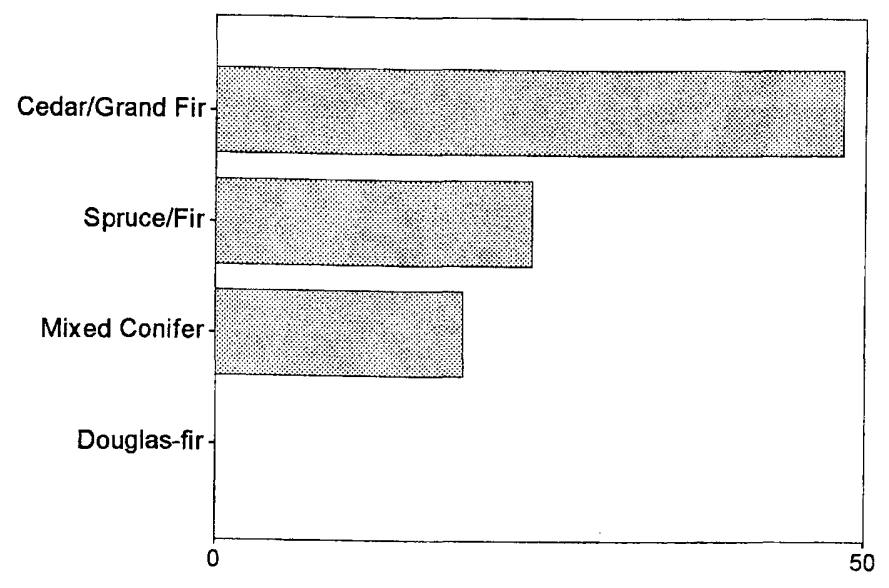

Percent of points with detections

b. Winter Wren - mature forest only

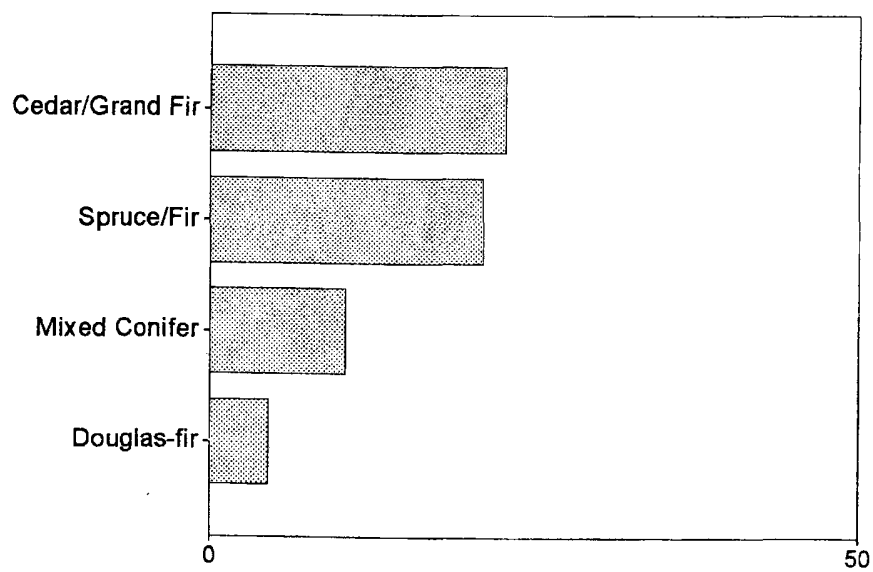

Percent of points with detections
Figure 53

Winter Wren - westside of the Continental Divide

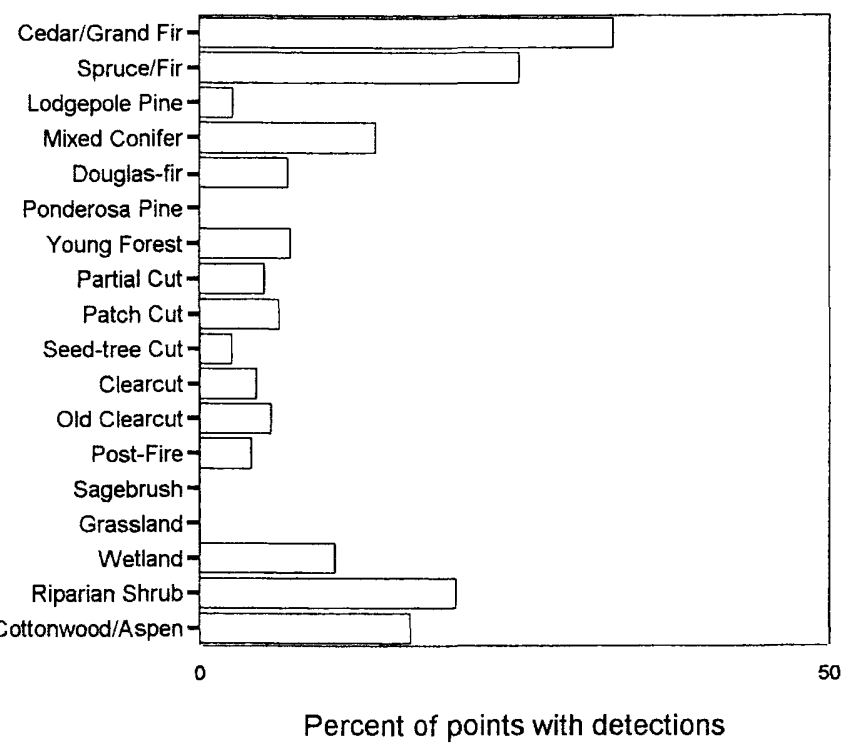


Golden-crowned Kinglets (fig. 54) were detected on 408,506 , and 383 of the points in the 3 years, primarily in uncut forest types, especially Cedar/ Grand Fir and Spruce/Fir. They were detected in grand fir as often as cedar/hemlock (Fisher's Exact test, $\mathrm{p}=0.86$ ), and avoided more open, dry forests such as Ponderosa Pine. The clear trend of a decline in abundance within increasingly cut forests suggests that Golden-crowned Kinglets may depend on relatively uncut forest conditions. They clearly prefer the trees with dense foliage (nonpine), in which they forage and build their nests (Galati and Galati 1985). Based on the Breeding Bird Survey database, they are one of only seven species whose populations declined significantly from 1968 to 1991 (Hejl 1994). As with Red-breasted Nuthatch, Brown Creeper, and Mountain Chickadee, this is a species for which virtually every timber harvesting study has revealed a negative effect (Hejl and others 1995).

Golden-crowned Kinglets were more likely to be detected in old growth than in mature forests (35 percent versus 25 percent, $p<0.001$ ). This trend held up within every cover type except Spruce/Fir. The pattern of cover type use displayed by this species does not seem to have been biased by its apparent preference for old growth, since the pattern was the same using data from mature stands only. The only difference with old growth stands included was a relatively lower detection probability in Spruce/Fir. Because old growth spruce/fir is known to be an excellent habitat for this species (Galati and Galati 1985), the low probability of detection therein may have been due to a low sample size (37) in that cover type. It seems clear, however, that maintenance of healthy populations of Golden-crowned Kinglets will probably require maintenance of large amounts of older forest.

The soft, high-pitched song of the Golden-crowned Kinglet makes it one of the most difficult species to detect, and this was reflected in the lowest average detection distance of any species $(32.7 \mathrm{~m}$ versus $53.0 \mathrm{~m}$ for 40 species combined). However, average detection distances did not differ greatly among cover types, and any bias would be expected to be in the direction of greater detectability in open cover types. This means there could be an even greater preference of uncut over cut forest cover types than was demonstrated here.
Figure 54

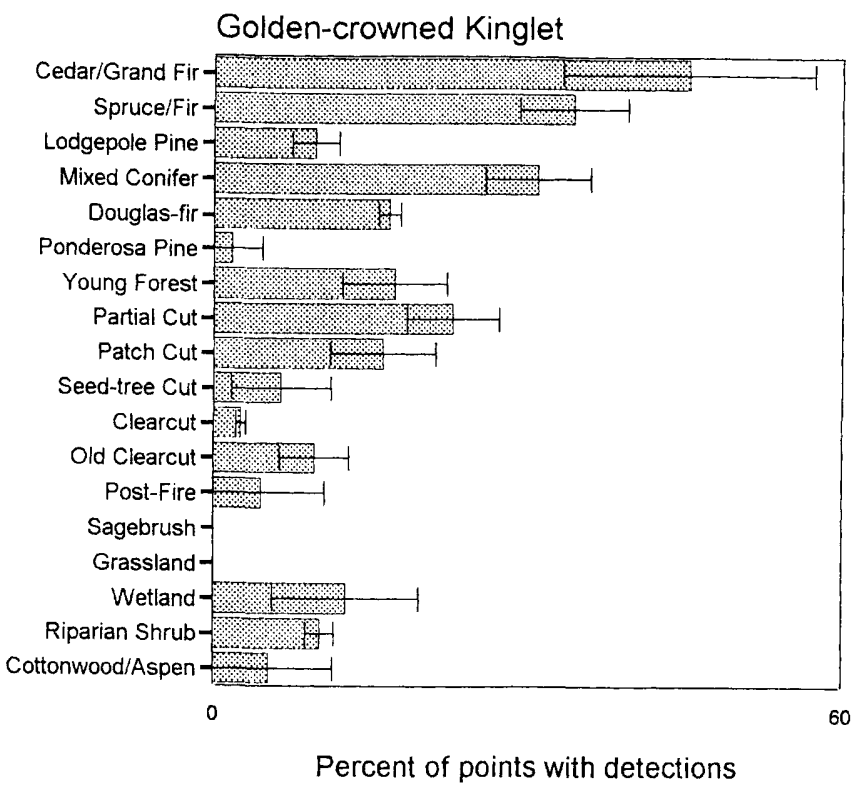


Ruby-crowned Kinglets (fig. 55) were detected on 591, 586, and 465 of the points in the 3 years, primarily in conifer forest cover types. The apparent abundance of kinglets in riparian cover types was probably an artifact of the species being detected in nearby conifer forest types. In fact, within the conifer cover types it was less commonly detected when riparian cover was within $100 \mathrm{~m}$ (21 percent) than in the stands with no edge within $100 \mathrm{~m}$ ( 25 percent). This species commonly occurred in partially cut forest types, although it was rare in Clearcuts. Use of partially logged forest is somewhat inconsistent with results presented in Hejl and others (1995), and we need more study of what conditions promote increased abundance and nesting success in harvested stands.

Song activity of the Ruby-crowned Kinglet declined in the later part of the season. This may mean that the probability of occurrence in Spruce/Fir is even higher than appears here, since this cover type was not as well represented earlier in the season. When data were restricted to before June 28 , the habitat distribution remained largely the same, except that the relative detection probability in Lodgepole Pine was increased (fig. 56).
Figure 55

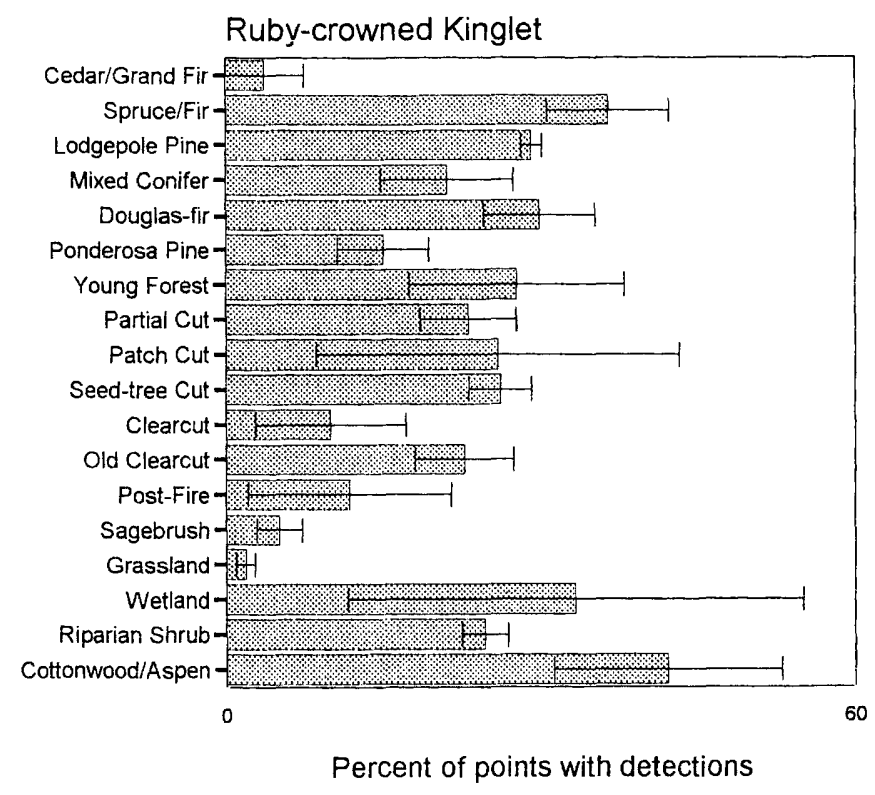

Figure 56

Ruby-crowned Kinglet - through June 28, when 80 percent of detections occurred

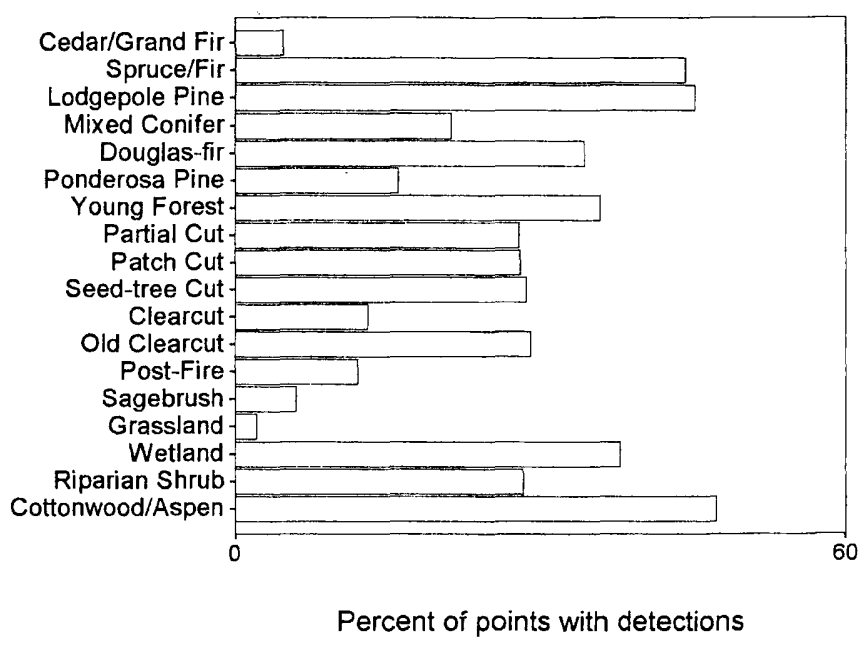


Mountain Bluebirds (fig. 57) were detected on 74, 65 , and 37 of the points in the 3 years. This species is likely to be found in any heavily logged or other open area that has sufficient nesting cavities. Note that it disappears as the age of a Clearcut advances. Because this species is most often detected visually, there may be a detectability bias toward more open cover types. However, considering the near total absence of detections within denser forests in this and other studies, this pattern may be considered reliable. Their association with early Post-Fire habitat is clearly evident, especially when one considers that the abundances reflected in the open Grassland, and Sagebrush cover types are likely to be an artifact of roadside nest boxes. A decline in detectability of this species as the season progressed resulted in 80 percent of the detections occurring by June 25 . However, restricting the data to this period did not change the habitat distribution pattern.

There are three issues of management interest here. First, this cavity-nesting species depends heavily on (is relatively restricted to) postfire habitat. This means that fire suppression and postfire salvage cutting operations may be affecting bluebird populations negatively. Data on reproductive success of Mountain Bluebirds in unlogged and salvage-logged postfire forests (Hitchcox 1996) suggest that both abundance and nest success may be lower in salvage-logged areas. The second issue is that the moderately high abundance in Seed-tree Cuts suggests either that this cutting style is a good surrogate for early postfire habitat, or that we are creating an "ecological trap" for this species. Studies of nesting success are clearly needed. Third is the use of nest boxes along public roadsides, which may create populations of this species in places they would not otherwise occur. From an ecosystem standpoint, introduced species often do more harm than good, so unless we need a last ditch effort to save the species, such activities should probably be discouraged.

Townsend's Solitaires (fig. 58) were detected on 275,199 , and 178 of the points in the 3 years. This species was common in both cut and relatively uncut conifer forests, but tends to prefer drier and more open cover types. The only potential management issue that we see is whether nest success is as good as suggested by the relatively common occurrence in harvested forest types. This appears to be a bird species of little management concern otherwise.
Figure 57

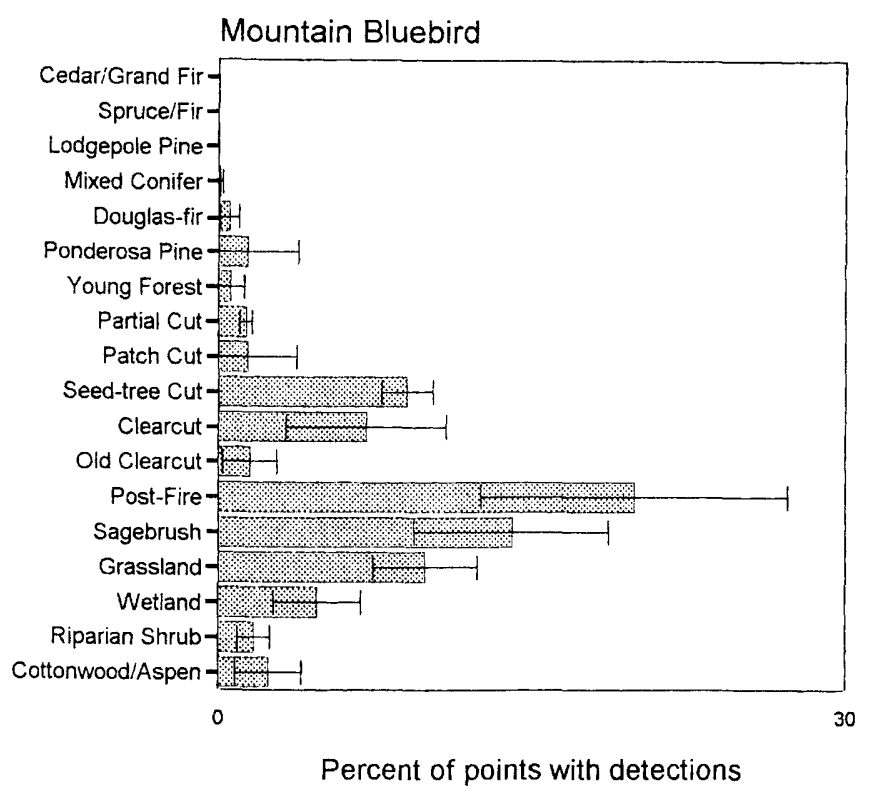

Figure 58

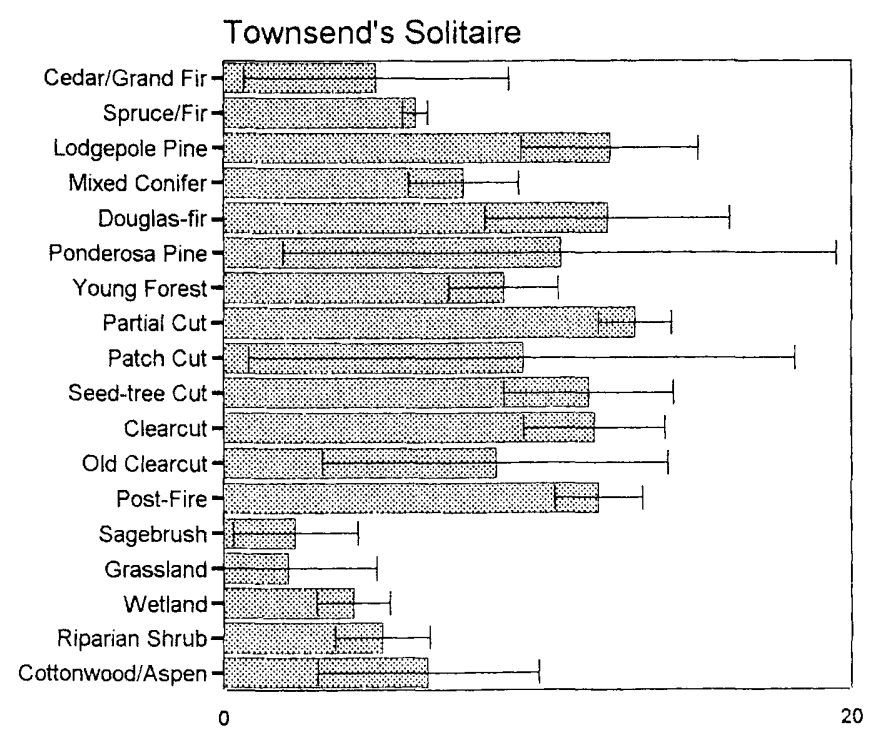

Percent of points with detections 
Swainson's Thrushes (fig. 59) were detected on 1064,585 , and 566 of the points in the 3 years. This species is associated with the understory shrub layer in coniferous forests, so it was detected most often in the moister forests and the later successional stages of logged stands. Old (pole/sapling) Clearcuts and Young Forest were consistently used at a high probability. All types of cut forests were also commonly used, making this another species for which data on nest success in harvested forests is needed to determine whether these conditions are as suitable as suggested by the distribution data. The species was also common in or near riparian areas. It was as likely to be found in grand fir as in cedar/hemlock (Fisher's Exact test, $p=0.73$ ).

Although it is a common species, the Swainson's Thrush was rarely detected early in the season (fig. 4), and the strong increase in detectability as the season progressed was more pronounced than for any other species. This may have biased some probability estimates for cover types that were unevenly sampled through time. In particular, the probability of occurrence in Spruce/Fir may be lower, and that in Ponderosa Pine may be higher, than the data suggest. Restriction of the data to the period beginning on June 14 (including 80 percent of detections) resulted in the expected change for Ponderosa Pine but little other difference (fig. 60).

As with most species, the average distance to detection was highest in Cedar/Grand Fir (except for the small sample in Ponderosa Pine). The average distances did tend to be higher in cut than in uncut stands, especially for Patch Cuts and recent Clearcuts, but there did not seem to be a pattern that would strongly affect the overall results.
Figure 59

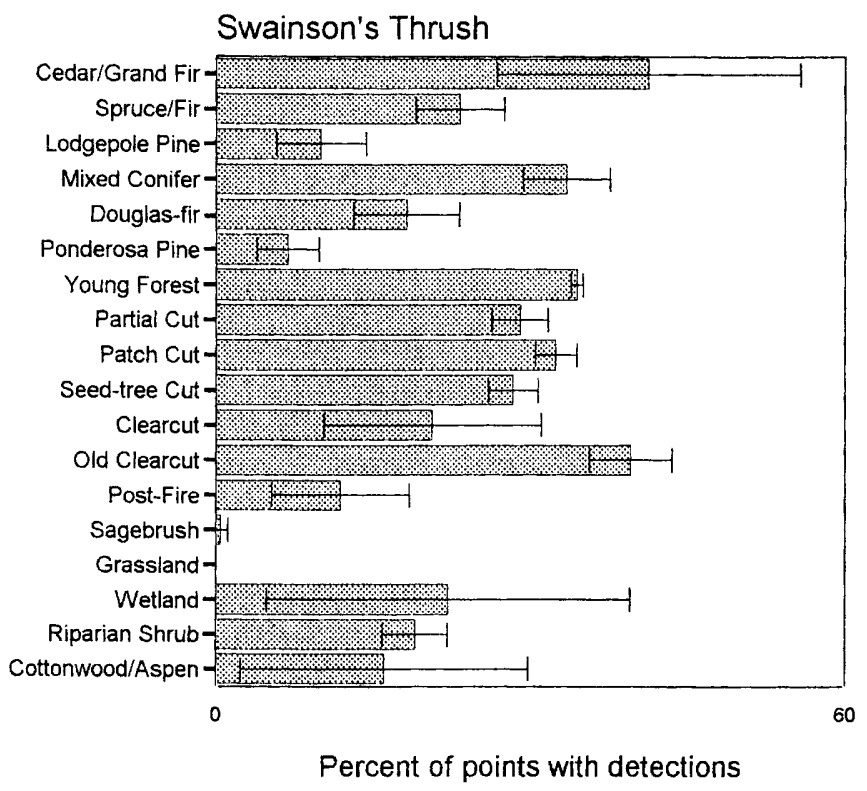

Figure 60

Swainson's Thrush - starting June 14 including 80 percent of detections

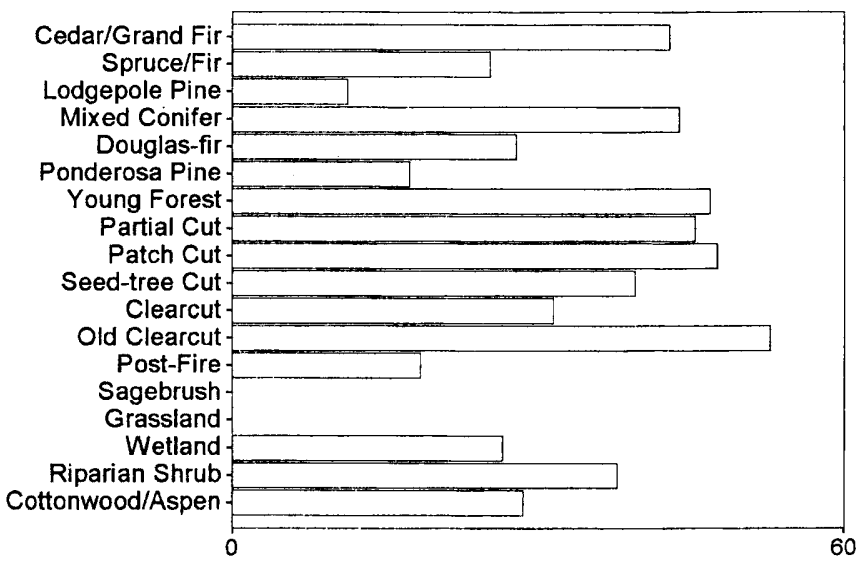

Percent of points with detections 
Hermit Thrushes (fig. 61) were detected on 126, 102 , and 119 of the points in the 3 years. This species is found most often in high-elevation Spruce/Fir forests, but also frequents drier coniferous cover types such as Ponderosa Pine. All nine detections in the Cedar/Grand Fir cover type were in cedar-hemlock, and all seven detections in Cottonwood/Aspen were in aspen. Although the cover types with highest probability of detection were uncut forests, most of the cut forest stands were in mixed-conifer, and there was no difference between partially cut and uncut mixedconifer stands. Within Spruce/Fir stands, Hermit Thrushes were detected in uncut forest slightly more often, but this was not significant $(p=0.42)$. Within the three most used cover types, the difference was nearly significant $(p=0.08)$. Most studies on the effects of either clearcutting or partial cutting show that Hermit Thrushes are affected negatively by such activities (Hejl and others 1995).

There was a pronounced and steady increase in the probability of detecting Hermit Thrushes as the season progressed ( 80 percent were detected beginning June 11). This was not entirely due to increased sampling of the Spruce/Fir cover type because the pattern remained without those data. Such an independent increase in detectability may have inflated our estimates of occurrence in Spruce/Fir, and underestimated the occurrence in Ponderosa Pine (which was mostly sampled early in the season). In fact, when data were restricted to the second half of the season (fig. 62), detections in Spruce/Fir remained high, but the detection probability in Ponderosa Pine was even higher (although the sample size was small; $\mathrm{n}=35$ ). In our experience, these two cover types are indeed the most widely used by Hermit Thrushes in the Northern Rockies.
Figure 61

Hermit Thrush

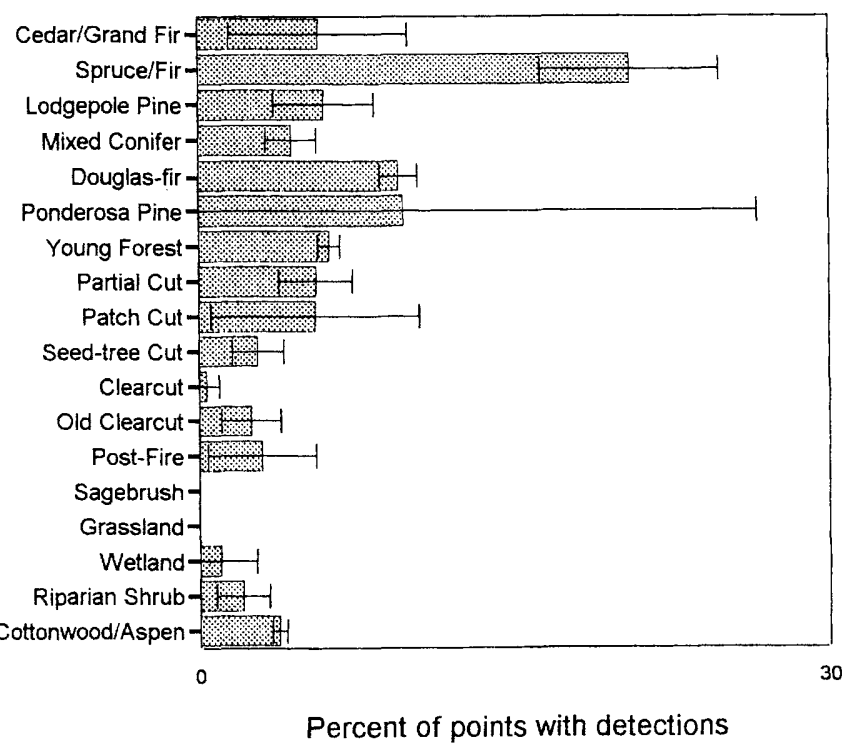

Figure 62

Hermit Thrush - starting June 11, date restricted to second half of the season

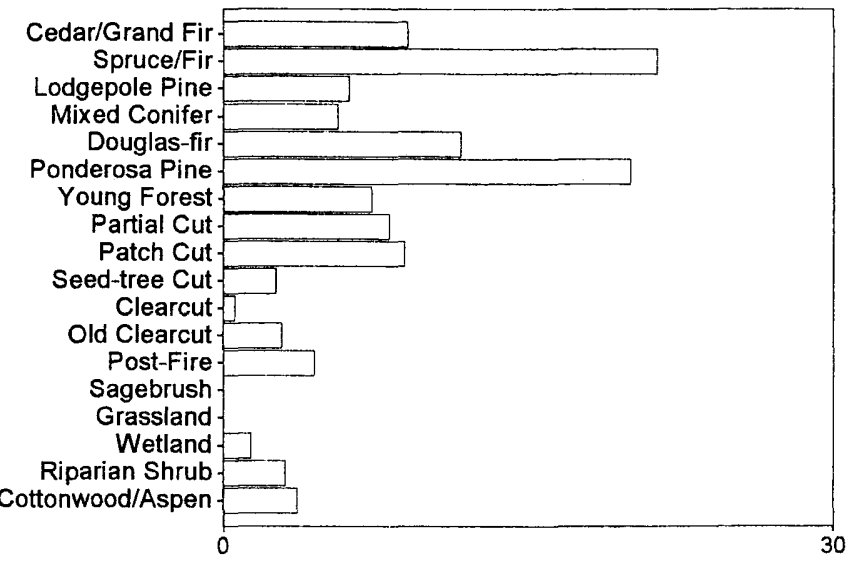

Percent of points with detections 
American Robins (fig. 63) were detected on 624, 538 , and 403 of the points in the 3 years, where they occurred in virtually every cover type available. They were most commonly detected, however, in riparian areas and in early successional forest stages after cutting or fire. They were more likely to be found in grand fir than in cedar-hemlock (23 percent versus 11 percent; Fisher's Exact test, $p=0.05$ ). They were detected evenly across the season, and although they were more common in mature forest relative to old growth ( $p=0.006)$, there is no reason to suspect biases in the habitat distribution of this conspicuous and ubiquitous species. Because of their commonness and their breadth of cover type use, robins pose no special management concerns.
Figure 63

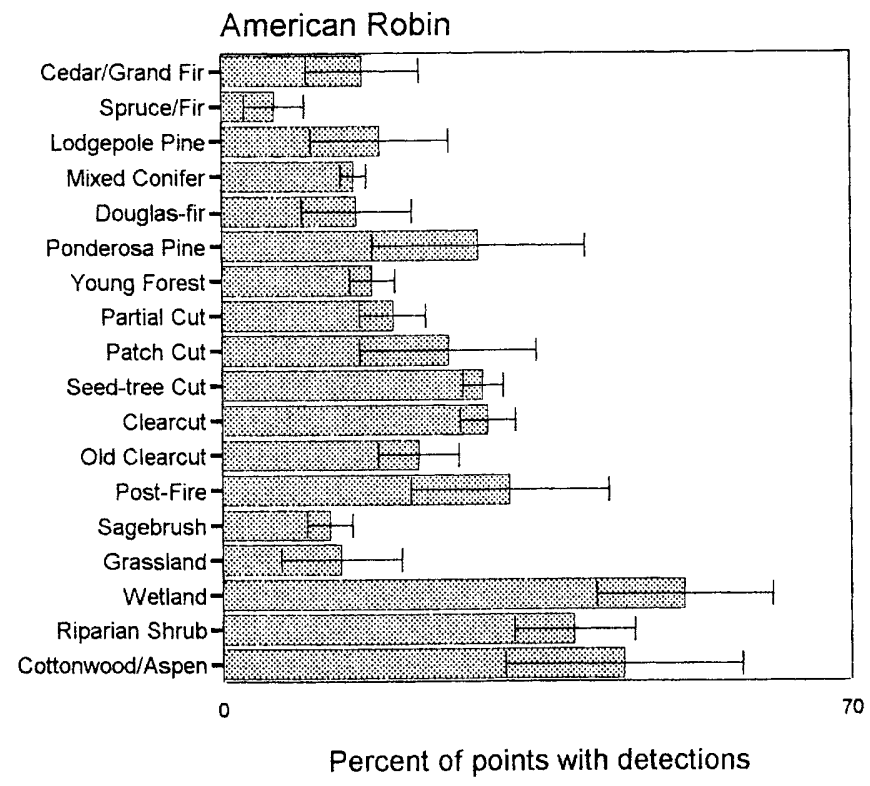


Varied Thrushes (fig. 64) were detected primarily in the western portion of the region on 209,266 , and 152 of the points in the 3 years, primarily in uncut Spruce/Fir and Cedar/Grand Fir forests. They were much more likely to be seen in cedar-hemlock than in grand fir stands ( 25 percent versus 8 percent, $p=0.01$ ). Even within the mixed-conifer cover type (1994 only), the species was much more likely to be detected when at least some cedar/hemlock (21 percent versus 8 percent) or spruce/fir (17 percent versus 9 percent) trees were present.

Of 627 detections of Varied Thrushes over 3 years, only 11 occurred east of the Continental Divide. This is the eastern edge of their range in Montana, as confirmed by long-term distribution records (Montana Bird Distribution Committee 1996). It is not known whether this distribution is due only to habitat availability or to some independent climatic factor. When the analyses were redone with data restricted to west of the Divide, the same habitat distribution pattern emerged, although with an even higher probability of detection in Spruce/Fir relative to the other cover types.

Within mixed-conifer forests, this species was more likely to be detected in mature than partially cut stands ( 14 percent versus 9 percent, $p<0.001$ ). However, this was not the case within Spruce/Fir or Cedar/ Grand Fir, and the trend was actually reversed. Virtually every timber harvesting study that has been conducted in the Rocky Mountains has revealed a negative effect of timber harvesting (Hejl and others 1995), so it may be of interest to discover what factors may ameliorate the effect of timber harvesting for this species.

This species is more likely to be detected in old growth than in mature forest (20.2 percent versus 11.6 percent, $\mathrm{p}<0.001$ ). This is most pronounced within Spruce/Fir forests, and it is also true within mixed-conifer (but not Cedar/Grand Fir). Only the Winter Wren and Brown Creeper showed a stronger affinity for old growth. Thus, the maintenance of viable populations of this species may depend to some extent on the maintenance of some amount of older, uncut conifer forest, especially Cedar/Grand Fir and Spruce/Fir. This affinity did not bias our results, however, because the distribution pattern was similar within mature and within old growth.

A strong increase in detectability of this species as the season progressed resulted in 80 percent of the detections occurring from June 7 onward, which was only partly due to an increase in sampling of its preferred habitat. However, restricting the data to this period did not change the habitat distribution pattern. Likewise, although only 11 detections occurred east of the Continental Divide, restricting the data to westside points did not change the habitat distribution results in any meaningful way, nor did a combination of time and geographic restrictions.
Figure 64

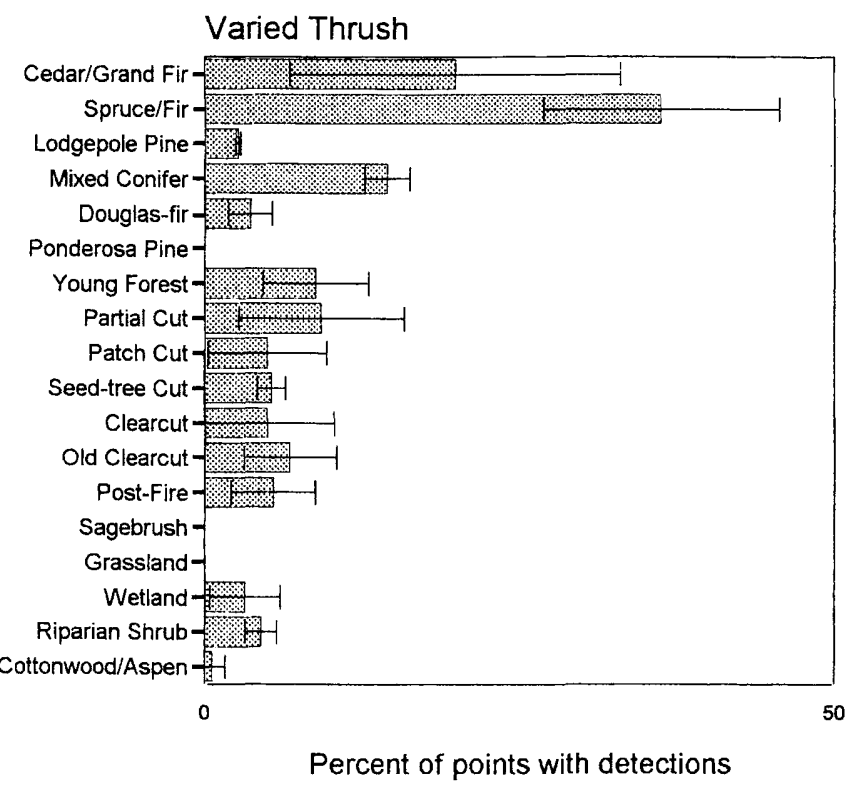


Cedar Waxwings (fig. 65) were detected on 53 points in all 3 years combined. This species is relatively restricted to riparian vegetation types, so it shares the same concerns that accompany similarly restricted species: Are streamside management practices providing for the needs of species that are relatively restricted to such conditions? Grazing issues might be particularly important for this species because it depends on the fruit resources provided by shrubs, which is one vegetation layer that virtually disappears under heavy grazing pressure.
Orange-crowned Warblers (fig. 66) were detected on 217, 176, and 171 of the points in the 3 years. This warbler species uses shrubby patches within uncut forest and is more widely distributed throughout early successional forests after the disturbance caused by tree harvesting. This is a classic example of a species that is more abundant in harvested forest types than in any of the other cover types. The main management concern is one of whether the species is doing well in those artificially created forests where it is abundant. In such situations, we really need to know whether we are creating "ecological traps" or not.
Figure 65
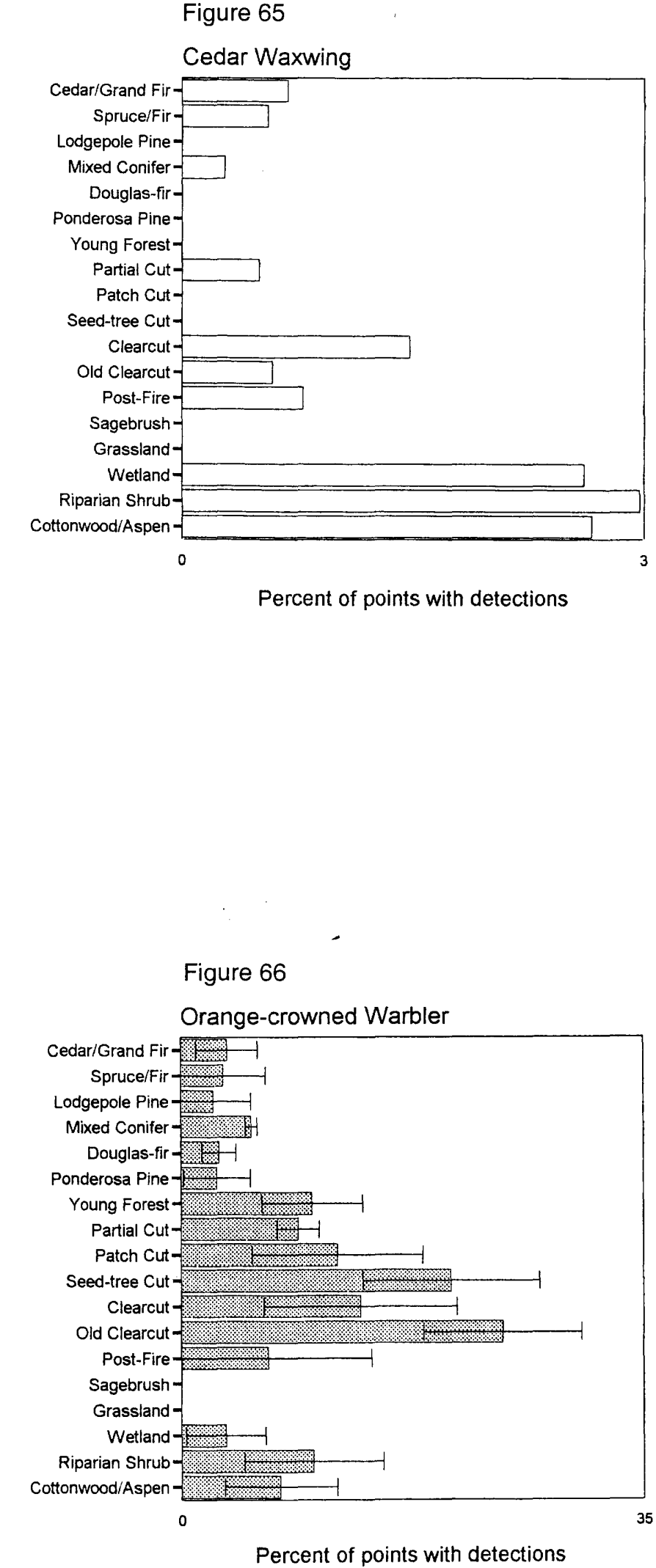
Nashville Warblers (fig. 67) were detected on 49 , 54 , and 37 of the points in the 3 years, primarily in Cedar/Grand Fir and Riparian Shrub communities and the drier forest types. This species is restricted in our region to west of the Continental Divide (Montana Bird Distribution Committee 1996). We had only three detections on the eastside, in the Lewis and Clark National Forest. Restriction of the data to the westside showed the species to be most frequently detected in Douglas-fir and Riparian Shrub. However, restriction of data to the period through June 24 (including 80 percent of the detections) resulted in a different pattern, and a combination of both restrictions (fig. 68) changed the pattern again. Apparently, the small sample sizes of both the birds and some of the cover types make the results sensitive and the conclusions questionable. This is an uncommon species that is more attuned to shrubby microhabitats than to any particular cover type, and thus its specific habitat requirements cannot be sufficiently delineated by this survey. The affinity for Patch Cuts (such as group selection cuts) is interesting and logical, but needs to be confirmed with larger samples.
Figure 67

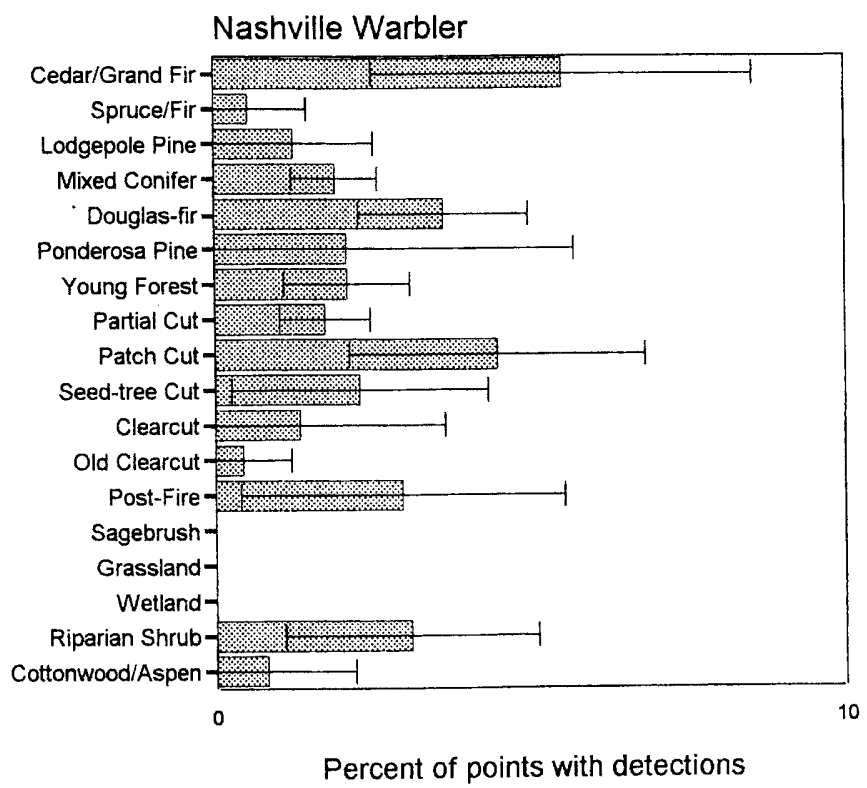

Figure 68

Nashville Warbler - to June 24, westside of the Continental Divide

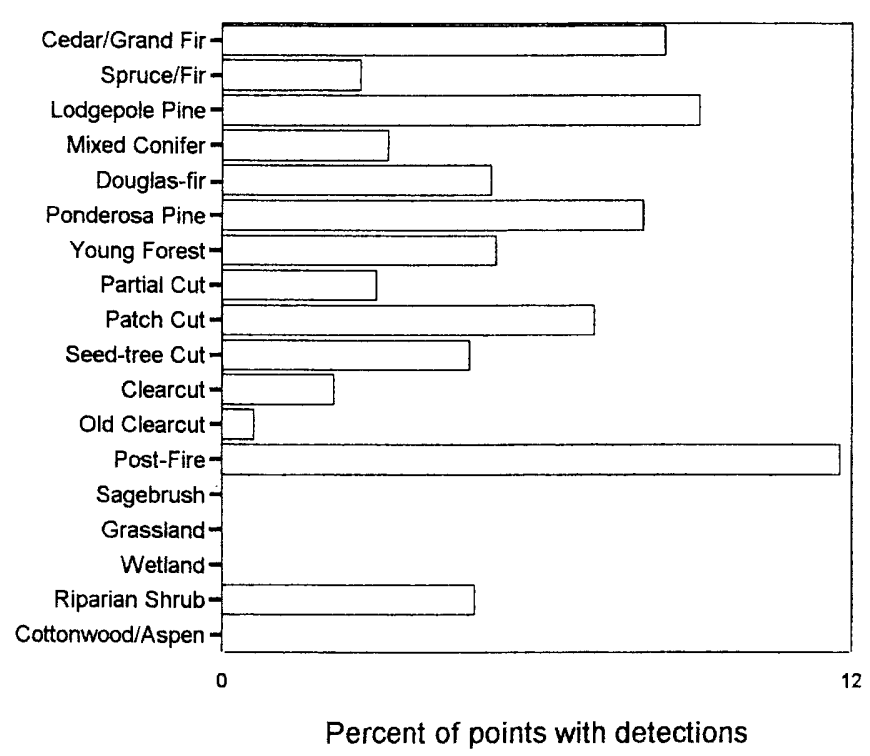


Yellow Warblers (fig. 69) were detected on 101, 74 , and 57 of the points in the 3 years. This is a riparian obligate species that is most common in riparian areas with well developed shrub layers and large deciduous trees-this includes riparian bottomlands and streamside shrublands (as well as some urban areas). They were much more likely to be detected in cottonwood than in aspen stands (40 percent versus 6 percent; Fisher's Exact test, $\mathrm{p}<0.001$ ). Because this species is restricted to riparian cover types, and those types occupy so little land area, it becomes critical to evaluate whether the species is doing well in what little area it occupies. There may be a problem with cowbird parasitism, especially in the bottomlands, where fragmentation and cattle ranching are more common (Tewksbury and others 1998).
Figure 69

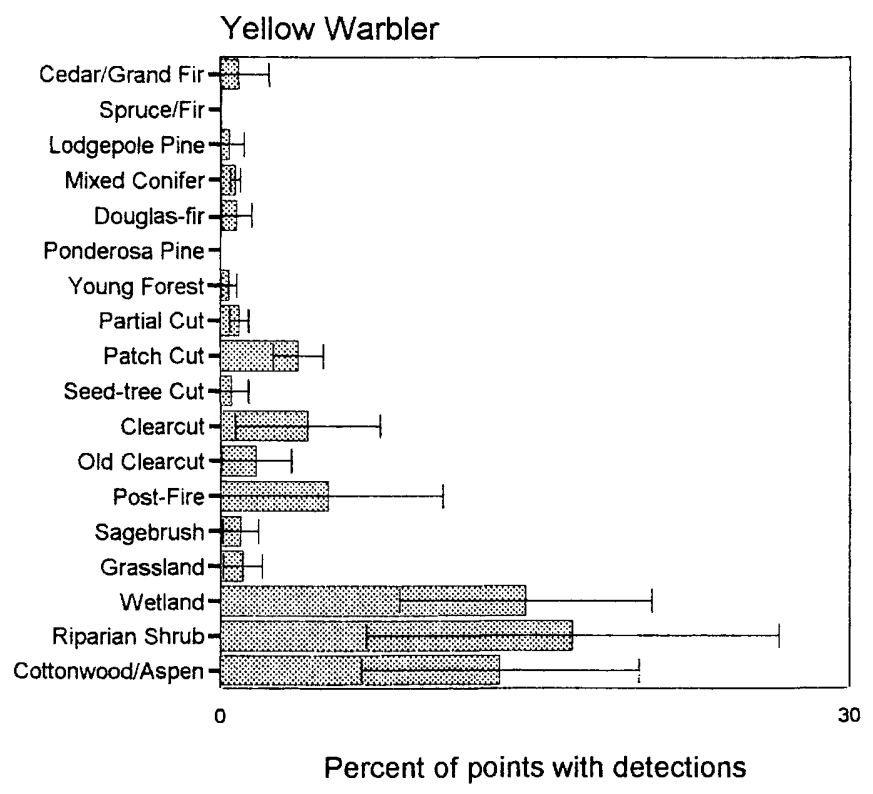

Figure 70

Yellow-rumped Warblers (fig. 70) were detected throughout the western part of the region on 1022 , 932 , and 764 of the points in the 3 years. They were most common in the more open, dry conifer forest cover types, but were fairly common in the variously harvested forest types as well. As our most abundant warbler and one of the most abundant forest species in the region, this species does not pose any special management concerns unless the harvested forest types act as "ecological traps" within which the birds do poorly despite their abundance. Yellow-rumped Warblers certainly would not be expected to do as well in Clearcuts, where they were frequently detected, but the relationship between tree retention levels and reproductive success needs to be studied.

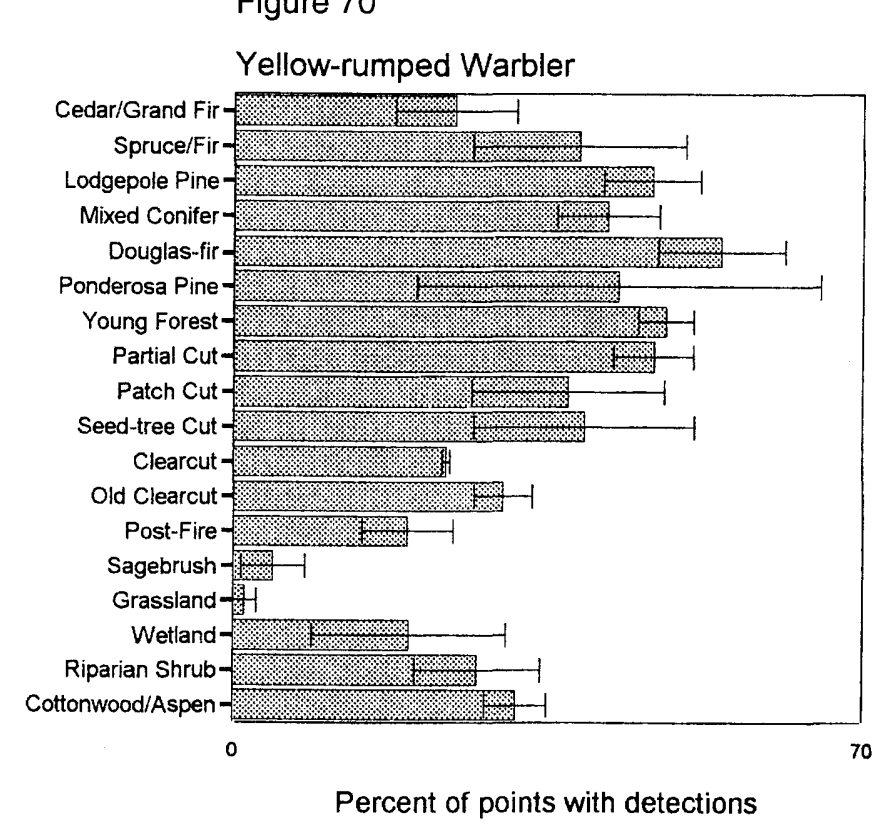


Townsend's Warblers (fig. 71) were detected primarily in the westernmost part of the region on 614,611 , and 599 of the points in the 3 years, primarily in the coniferous forest cover types. Townsend's Warblers were notably less abundant in the drier and more open forest cover types, clearly avoiding pine. The clear trend of a decline in abundance within increasingly cut forests suggests that Townsend's Warblers may depend on relatively uncut forest conditions. It was twice as likely to be detected in grand fir as in cedar-hemlock (87 percent versus 43 percent). Even within Mixed Conifer (1994 only), the detection probabilities in stands with (64 percent) or without (32 percent) grand fir differed slightly more than stands with (59 percent) or without (36 percent) cedar-hemlock.

This species is probably sensitive to timber harvesting activity, as evidenced by a continuous decline in probability of occurrence with increasing amounts of timber removed. Indeed, a review of published studies of timber harvesting effects in the Rocky Mountains revealed that most studies of the effects of timber harvesting have shown a decline in abundance of Townsend's Warbler(Hejl and others 1995). Townsend's Warblers were detected as frequently in mature forest as in old growth $(0.35$ versus $0.32, p=0.42)$.

Townsend's Warblers are largely restricted geographically to west of the Continental Divide (Montana Bird Distribution Committee 1996). There were only 50 detections on the eastside, and they were over 16 times more likely to be detected on the westside. However, restriction of the data to westside points did not change the habitat distribution pattern, other than an increase in detection probability in Douglas-fir, bringing it even with Partial Cuts. A decline in detectability of this species as the season progressed resulted in 80 percent of the detections occurring by June 27 . Restricting the data to this period did not change the habitat distribution pattern either (nor did a combination of time and geographic restrictions).
Figure 71

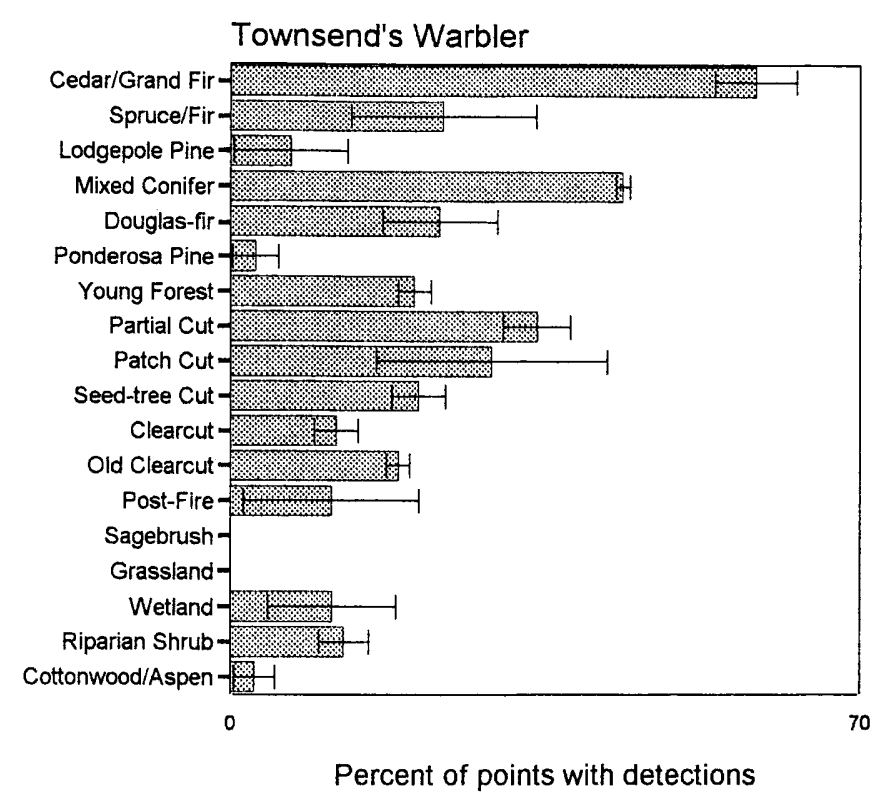


American Redstarts (fig. 72) were detected on 67 points in all 3 years combined, nearly exclusively in the riparian vegetation types. Within those types, they were further restricted to points that contained a good shrub layer. They were more likely to be detected in cottonwood than in aspen stands (19 percent versus 3 percent; Fisher's Exact test, $p=0.001$ ). The scattered observations from conifer forest types probably reflect either identification errors or a failure to detect that riparian vegetation was also nearby (which would have classified those points as "edge" and eliminated them from analysis). Nevertheless, some redstarts may occasionally show up in patches of deciduous regrowth in old harvest units. The apparent abundance in marshes is undoubtedly due to the presence of shrubs associated with the wetland complex. The most pressing concern here is whether "best management practices" near riparian areas are adequate to maintain productive redstart populations. The extent to which this species needs a matrix of relatively intact forest surrounding occupied streamside riparian corridors, for example, is unknown, but it has been shown to be vulnerable to cowbird parasitism, suffering about 40 percent parasitism rates in an ongoing study within the region (Tewksbury and others 1998).

Ovenbirds (fig. 73) were detected only east of the Continental Divide, on 36 points in all 3 years combined, primarily in Cottonwood/Aspen forests (14 of 15 detections in this cover type were in aspen). Although they are known to use Ponderosa Pine in eastside forests, which is also suggested here, this bar represents only four detections. Here is another species that is strongly associated with a cover type (Cottonwood/ Aspen) that occurs across less than 0.5 percent of all the land area in the region. Because of its limited habitat distribution, we need to know the effect of alternative riparian management regimes on both the presence and nesting success of this species, as well as more information on the conditions that make ponderosa pine stands suitable for this species.
Figure 72

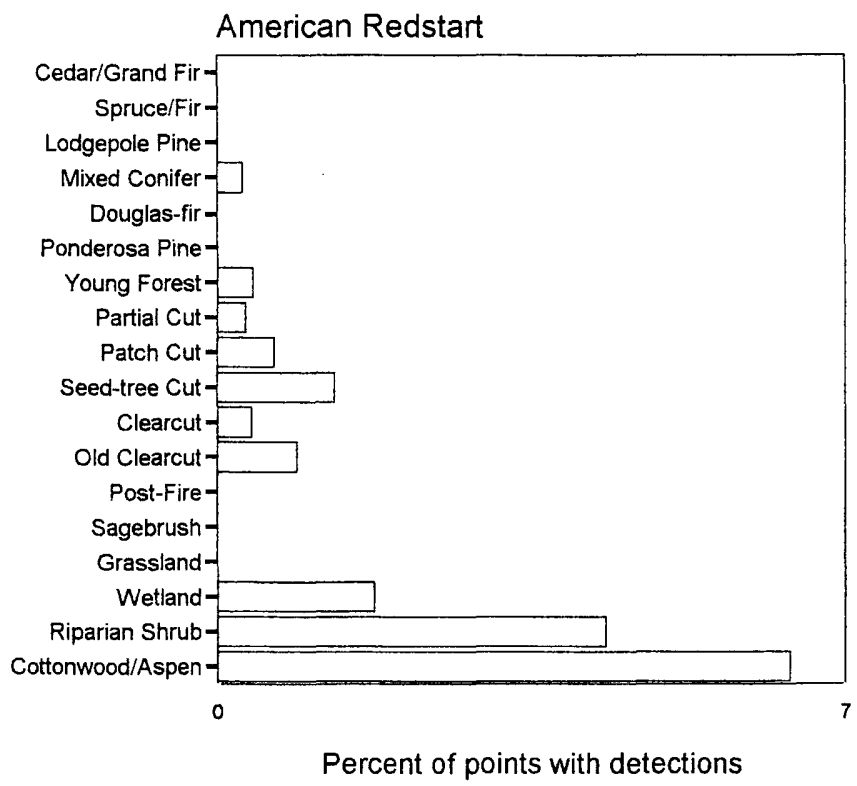

Figure 73

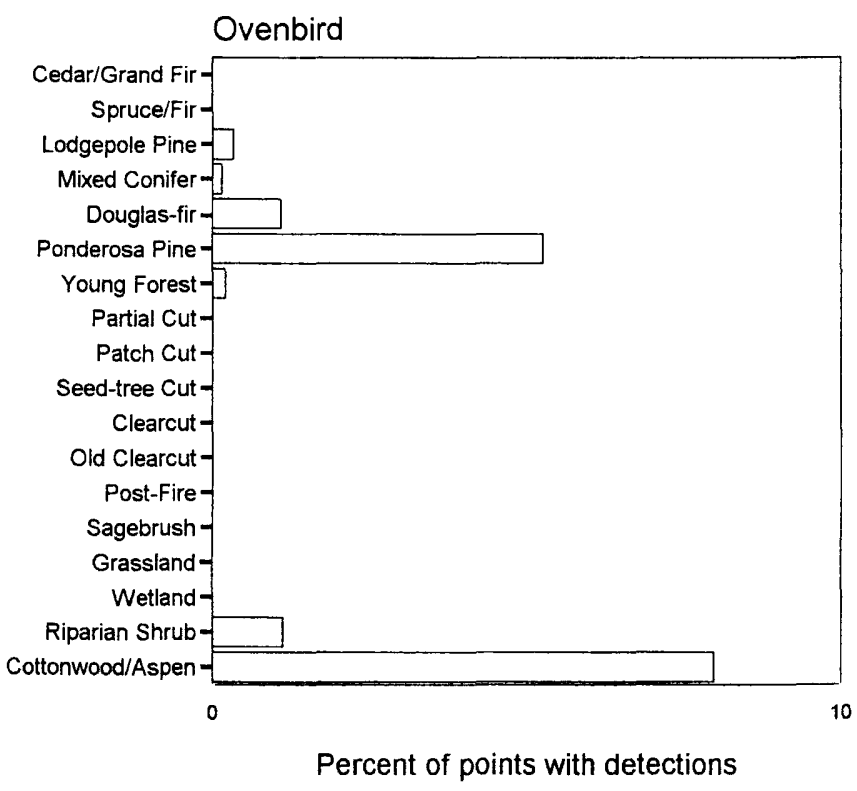


Northern Waterthrushes (fig. 74) were detected on 74 points in all 3 years combined, primarily in riparian areas. This species is probably more ripariandependent than indicated here. It occurs at small marshes and potholes within forested cover types, and such microhabitats are easily overlooked, so that observers may not have noted that a riparian cover type was near. We need to know which microhabitats are important for this species within conifer stands (note that the bar in Spruce/Fir represents only four individuals). This is another species that may be sensitive to streamside management practices and would, therefore, serve as a good indicator of whether streamside "best management practices" are serving the needs of wildlife species.
Figure 74

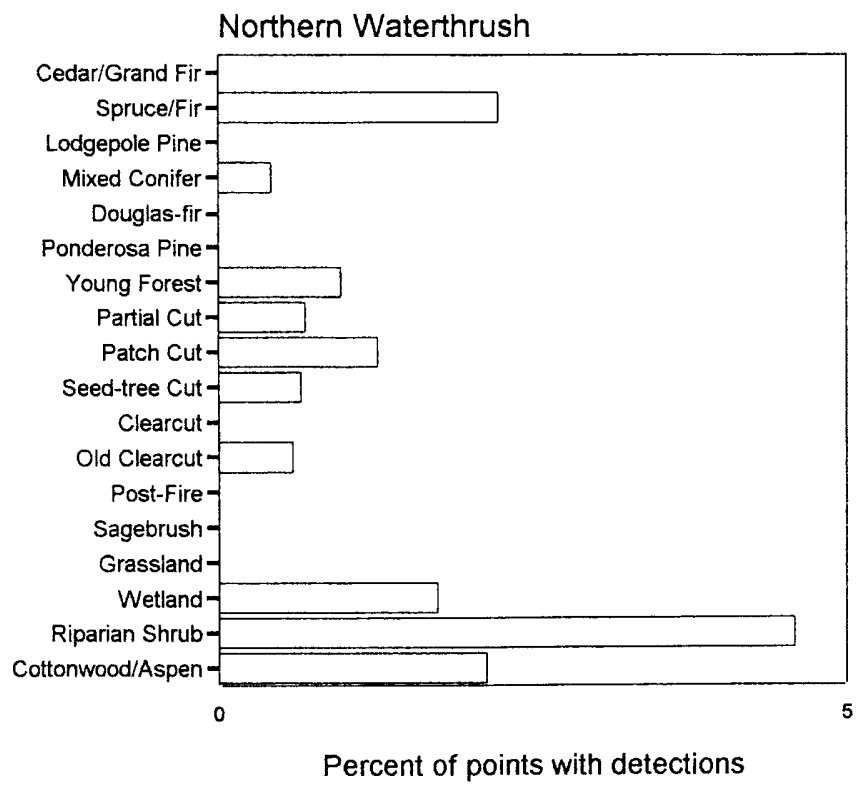

Figure 75

MacGillivray's Warbler

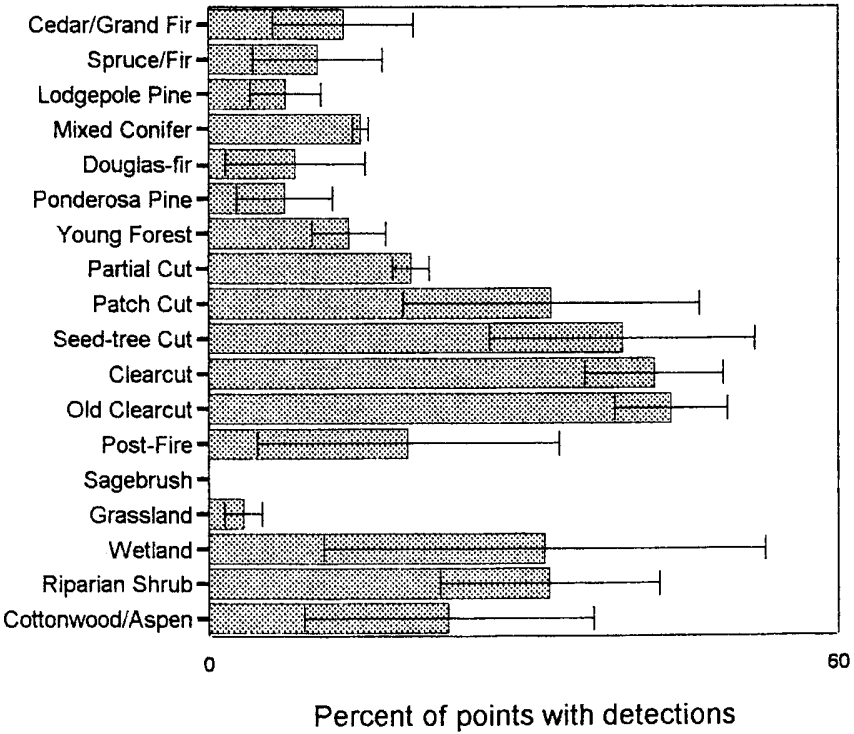

Percent of points with detections 
Common Yellowthroats (fig. 76) were detected on 26,38 , and 34 of the points in the 3 years, nearly exclusively in riparian cover types (especially marshes). Because this species is nearly restricted to marshes and willow flats, the draining of wetlands and the impact of adjacent land-use activity on this wetlanddependent species needs special consideration; without intact wetland areas, they have little habitat available. In aspen, cottonwood, and willow cover types, this species is negatively affected by grazing activity, and is nearly four times less abundant in grazed than ungrazed conditions (Saab and others 1995).
Figure 76

Common Yellowthroat

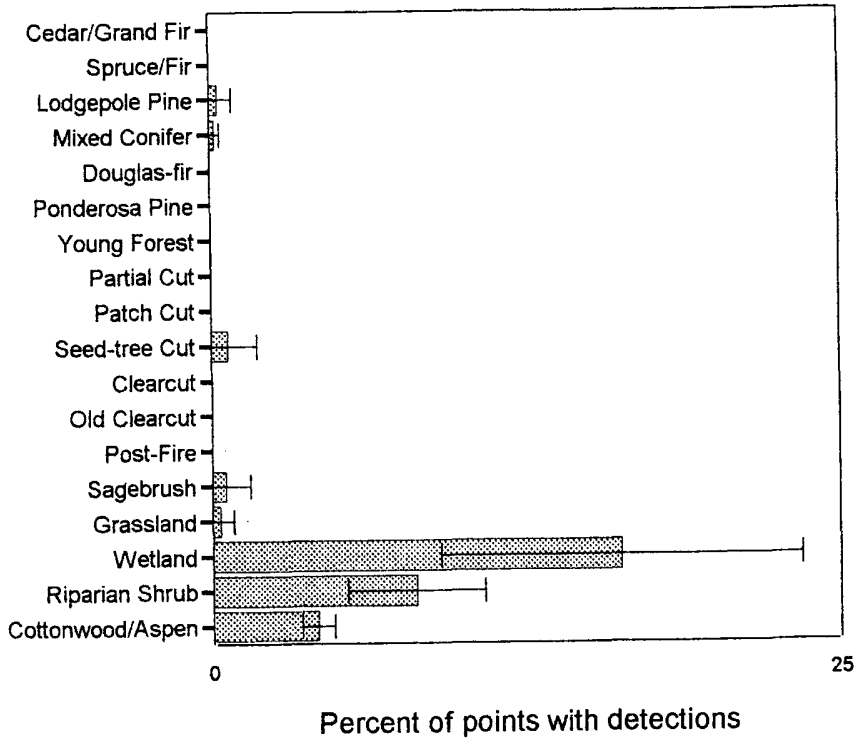


Wilson's Warblers (fig. 77) were detected on 74,76 , 108 of the points in the 3 years, primarily in higher elevation conifer forests. This species nests primarily in high elevation willow thickets (Stewart and others 1977), and although they may penetrate into upland forests with sufficient shrubs (perhaps affected by roads), most individuals are probably still associated with nearby water sources. Nine of 10 detections in the Cedar/Grand Fir cover type were in cedar/hemlock. Although not restricted to west of the Continental Divide (Montana Bird Distribution Committee 1996), the Wilson's Warbler was over five times as likely to be detected there. Restriction of the data to westside points (fig. 78) resulted in an even greater apparent use of high-elevation forests (Spruce/Fir and Lodgepole Pine), Old Clearcuts, Post-Fire, and shrubby riparian areas. In western Oregon, it frequents early growth clearcuts with sufficient deciduous saplings (Morrison 1981). In our experience, this species is relatively common in riparian areas within highelevation conifer forests. If so, this species may be more sensitive to streamside management practices than is implied by the distribution data. We may also need more surveys of high-elevation Wilderness areas to fully understand the habitat requirements and population status of this species in our region.
Figure 77

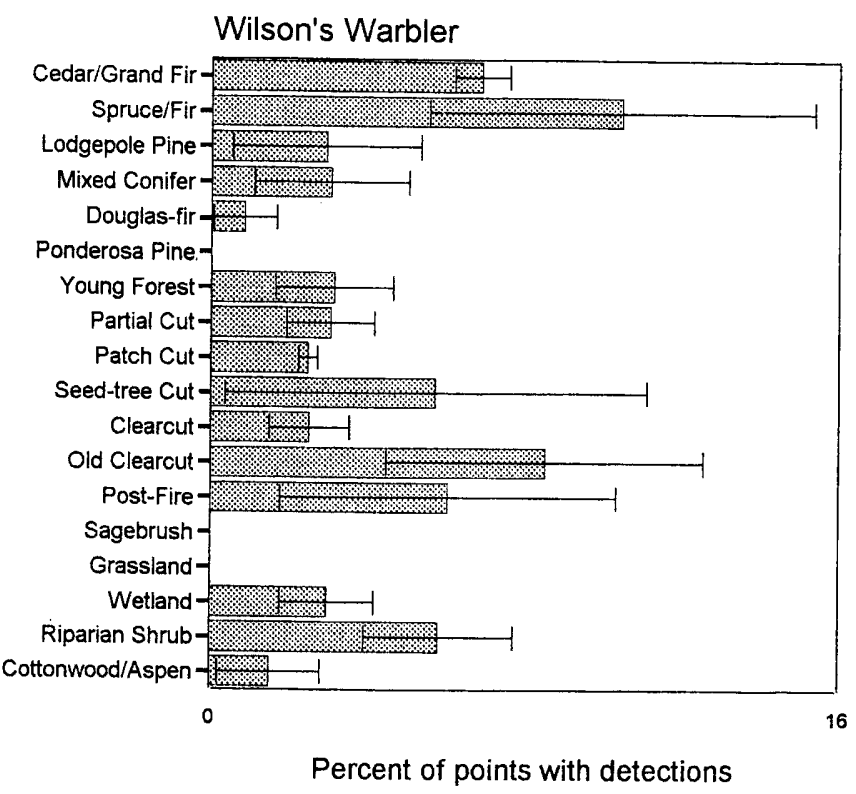

Figure 78

Wilson's Warbler - westside of the Continental Divide

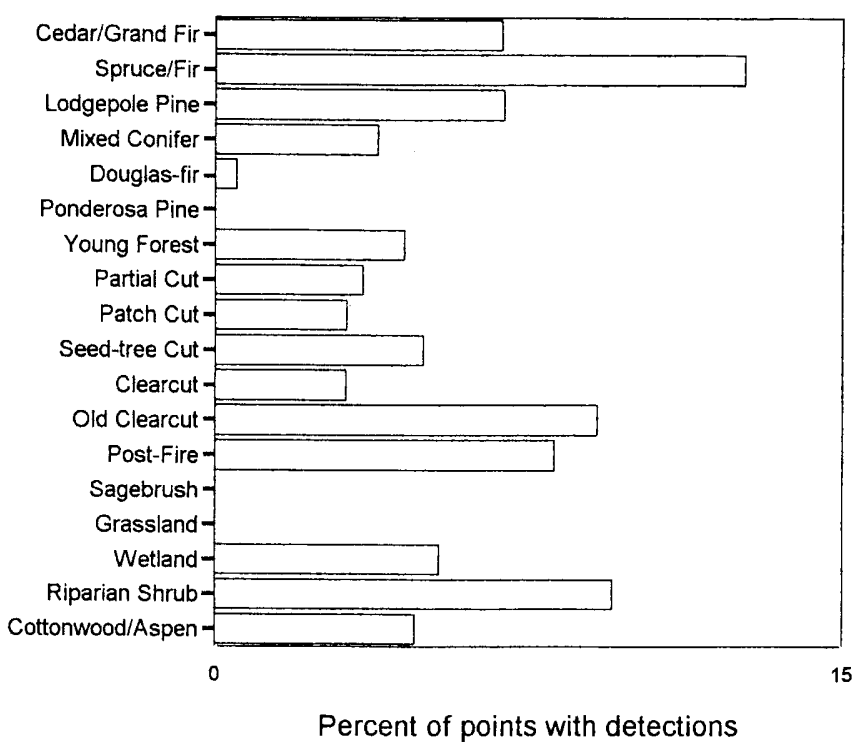


Western Tanagers (fig. 79) were detected on 663,486 , and 542 of the points in the 3 years. They occurred across a wide range of coniferous forest cover types, but were most common in the lower elevation and drier forest types, especially Ponderosa Pine and the harvested forests with a relatively large number of green trees left. Because tanagers are widespread across most coniferous forest types, there is probably not much of management concern here. The issue of primary importance is whether their relatively high abundance in harvested forest types reflects the suitability of those types or not. In many respects, harvested forest types are "unnatural," so they may not hold all necessary requisites for species such as the tanager, which may be attracted to those sites because of their superficial similarity to some naturally occurring cover type. This species is so widespread, both spatially and temporally, that its distribution pattern is probably unbiased.

Green-tailed Towhees (fig. 80) were detected in the south-central portion of the region on 49 points in all 3 years combined. They were relatively restricted to Sagebrush cover, as well as some riparian situations. The management issue of primary concern is probably whether this ground- or low-shrub-nesting species is affected negatively by grazing regimes in sagebrush.
Figure 79

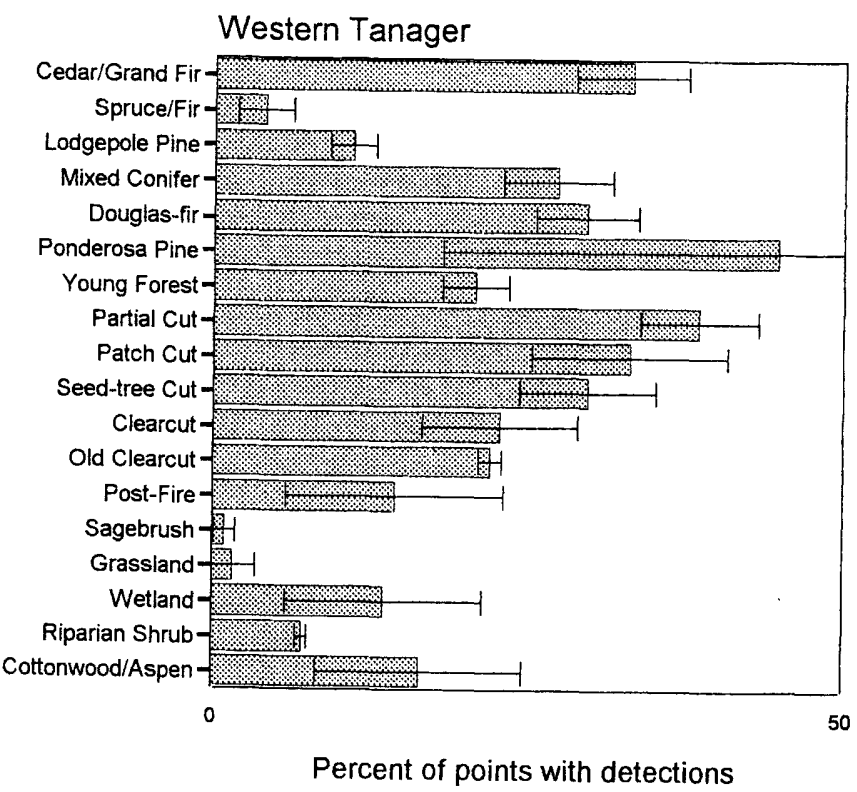

Figure 80

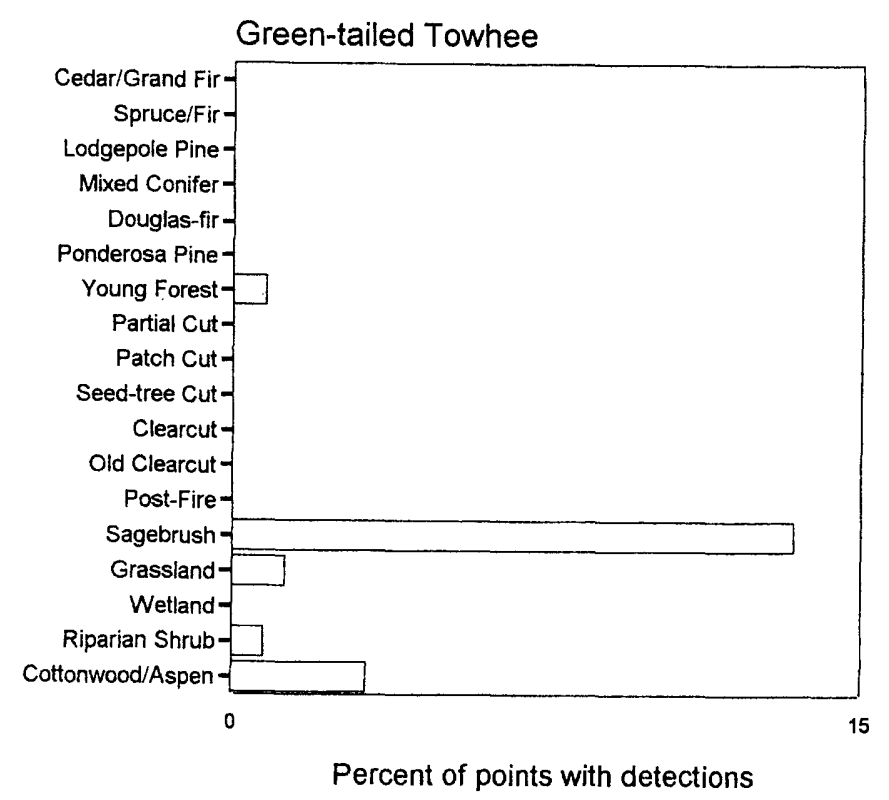


Spotted Towhees (fig. 81) were detected on 51, 65, and 61 of the points in the 3 years, primarily in the drier brushy areas within riparian areas, in early successional Post-Fire and Clearcut stands, and in the brushy draws in shrublands and Grasslands. A strong decline in detectability of this species as the season progressed resulted in 80 percent of the detections occurring by June 21 . However, restricting the data to this period did not change the habitat distribution pattern. The shrub microhabitats used by this species occur within a variety of open forest and range situations, so the broad cover types used here may not adequately reflect the needs of this species. The issue of primary management concern is livestock grazing, which is a common land-use practice in the cover types frequented by Spotted Towhees. A review of the literature on the effects of grazing in western riparian habitats did not suggest a problem, however (Saab and others 1995).

Chipping Sparrows (fig. 82) were detected on 698,480 , and 350 of the points in the 3 years, primarily in the open, dry forest types and in forests that have become open through timber harvesting activity. This species is abundant and widespread, yet recent (1968 to 1991) data on population trends in the West (Hejl 1994) show significant declines. Managers might need to look in some of the harvested forest cover types to see if reproductive success is as good as implied on the basis of our census data. There are two studies of grazing effects in bottomlands that have data on Chipping Sparrows, and both showed that the species was less abundant in grazed than in ungrazed sites (Saab and others 1995),
Figure 81

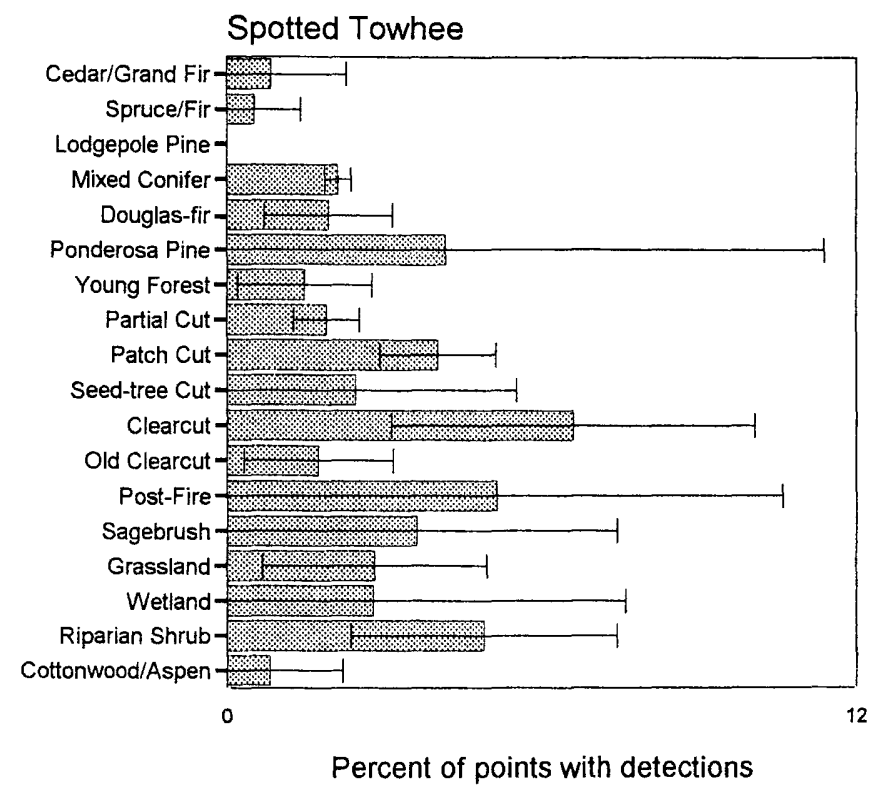

Figure 82

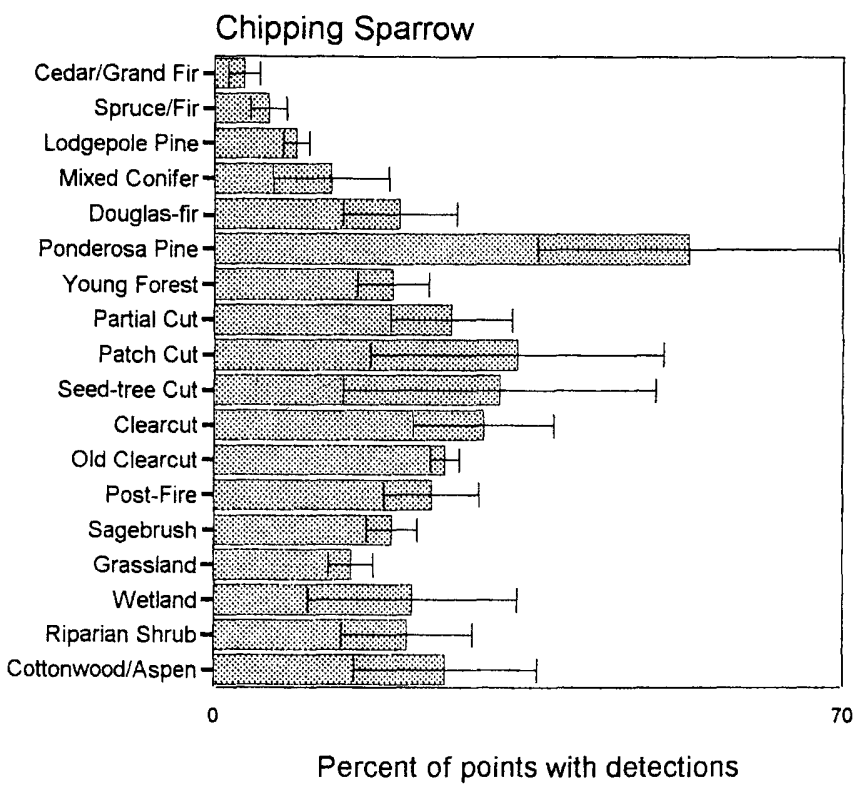


Brewer's Sparrows (fig. 83) were detected on 80 points in all 3 years combined, primarily in southwestern Montana. This species is nearly restricted to Sagebrush. Because the species is so highly restricted in its habitat distribution, and because Breeding Bird Survey data suggest that it is one of the most severely declining songbird species on a nationwide basis (Peterjohn and others 1996), we should be focusing on this species in studies of the effects of sagebrush landuse practices on wildlife species. We did not obtain enough data from both heavily grazed and lightly grazed conditions to comment on potential effects. Brewer's Sparrows have shown inconsistent responses to grazing in the past, but they may now be harmed by heavy grazing that continues to remove herbaceous cover (Saab and others 1995).

Vesper Sparrows (fig. 84) were detected throughout the eastern half of the region on 178, 146, and 101 of the points in the 3 years, primarily in Grasslands and Sagebrush (and in agricultural lands, as recorded in additional surveys not reported here). Permanent monitoring points on the westside of the Divide do not cover appropriate cover types for this species. Only the 101 extra Grassland and Sagebrush points sampled in 1994, as well as our personal experience, show this species to be abundant in appropriate habitat west of the Divide, at least in west-central Montana. This species declined in detectability through the season, with 80 percent of the detections occurring by June 28 . However, because this species was so strongly restricted to Grassland and Sagebrush, no subset of the data would change this pattern. We need information on the nesting success of this species under alternative management regimes in sagebrush and grassland cover types. Vesper Sparrows have shown inconsistent responses to grazing (Saab and others 1995).
Figure 83

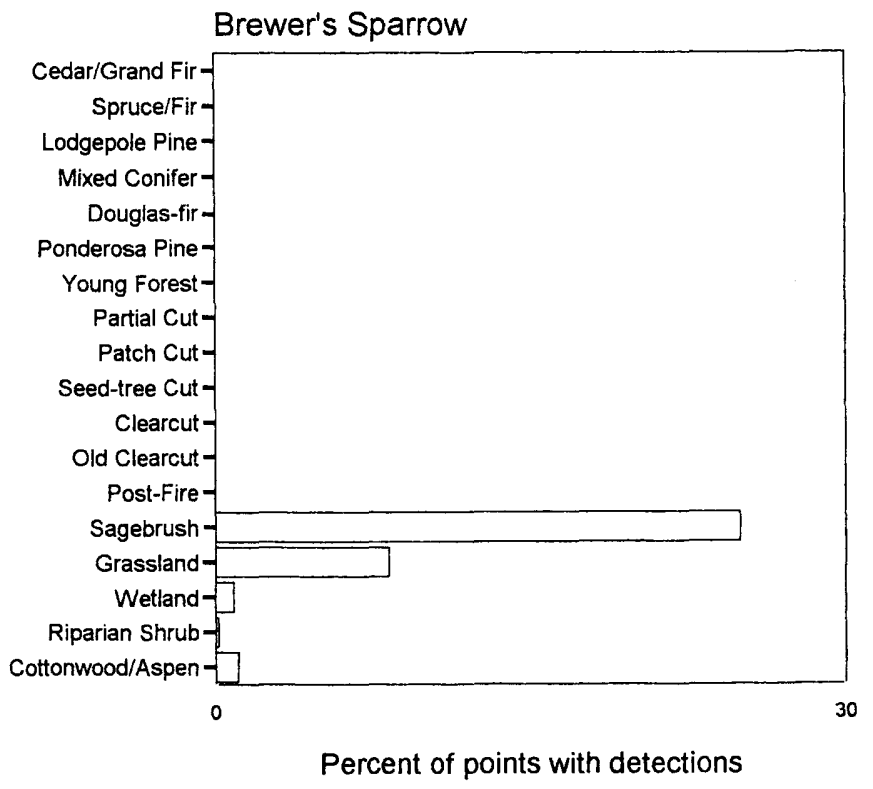

Figure 84

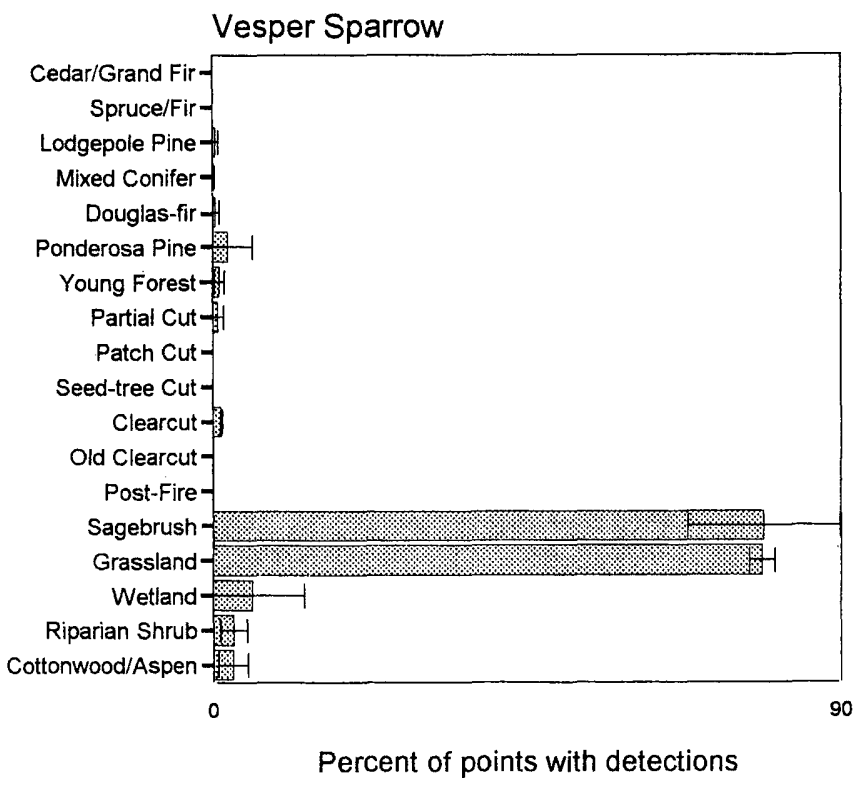


Savannah Sparrows (fig. 85) were detected on 40, 29 , and 26 of the points in the 3 years, in open Grassland and Sagebrush cover types. However, this species was even more frequent ( 73 percent) in 56 extra points we sampled in agricultural fields (not otherwise reported here). If this species is consistently drawn to agricultural fields, such a distribution would seem to beg for information on how well they do in terms of reproductive success. If they do poorly because of mechanical disturbance from farming activity, for example, then such fields would be acting as "ecological traps," especially since a disproportionately large segment of the bird population may be using such conditions. All studies to date on grazing effects in grasslands and shrubsteppe have shown this species to be affected negatively by grazing (Saab and others 1995). This species declined in detectability through the season, with 80 percent of the detections occurring by June 27. However, because this species was so strongly restricted to Grassland and Sagebrush, no subset of the data would change this pattern.

Grasshopper Sparrows (fig. 86) were detected on 30 points in all 3 years combined, nearly exclusively in Grasslands (the one observation in Spruce/Fir was not well documented). As with the other grasslanddependent species, Grasshopper Sparrows have been experiencing significant long-term (1966 to 1995) population declines (Peterjohn and others 1996) probably largely because of the conversion of land for agricultural purposes. There is also a clear need for information on the presence and reproductive success of this species in relation to grazing practices in grasslands; so far, the vast majority of studies on grazing effects in grassland have shown this species to be negatively affected (Saab and others 1995).
Figure 85

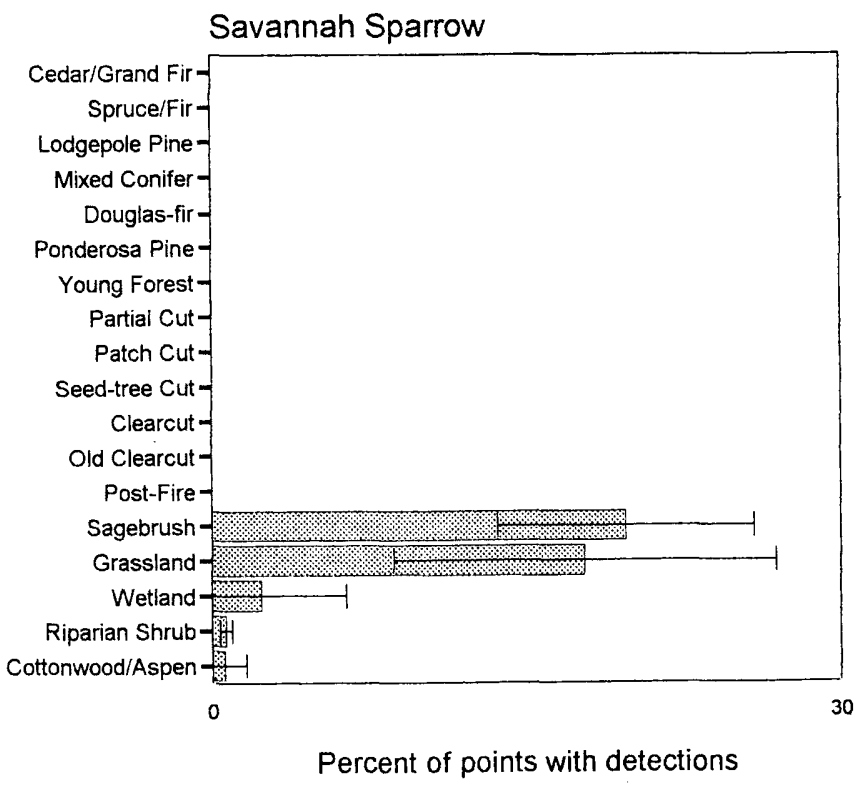

Figure 86

Grasshopper Sparrow

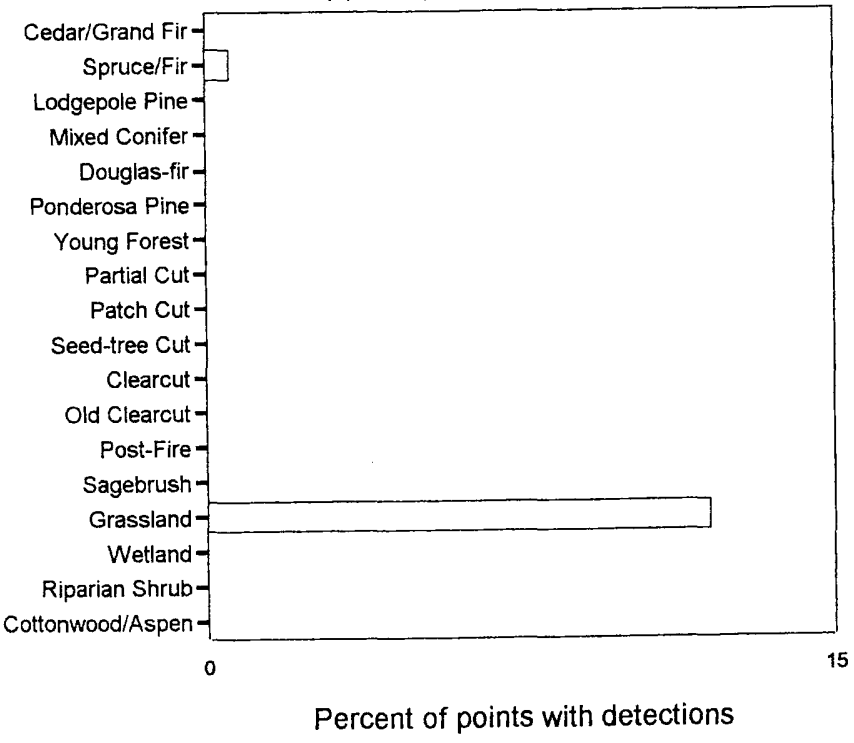


Fox Sparrows (fig. 87) were detected in the northwestern portion of the region on 99,128 , and 91 of the points in the 3 years. They are the only species for which we have data that show a relative restriction to higher elevation Spruce/Fir forests. Because of its uniquely restricted habitat distribution pattern in the Northern Rockies, this species might be a good one to use as an indicator of conditions in the spruce-fir zone. All six detections in Cedar/Grand Fir were in cedar-hemlock.

Although only four Fox Sparrows were detected east of the Continental Divide, restriction of the data to westside points did not change the habitat distribution pattern, except for an increase in detection probability within the Riparian Shrub cover type. A strong increase in detectability of this species as the season progressed resulted in 80 percent of the detections occurring from June 12 onward. However, restricting the data to this period did not change the habitat distribution pattern.

Song Sparrows (fig. 88) were detected on 135, and 110,124 of the points in the 3 years. They are relatively restricted to riparian streamsides, bottomlands, and marshlands. They were more likely to be detected in cottonwood than in aspen stands ( 42 percent versus 6 percent; Fisher's Exact test, p $<0.001$ ). This is another species that may be sensitive to streamside management practices and would, therefore, serve as a good indicator of whether "best management practices" are really serving the needs of wildlife species. Nationwide, from 1966 through 1995, this species has declined significantly (Peterjohn and others 1996), possibly due to cowbird parasitism, which is prevalent in the habitats Song Sparrows prefer. They are heavily parasitized in this region, affecting about 65 percent of nests in one study (Tewksbury and others 1998).
Figure 87

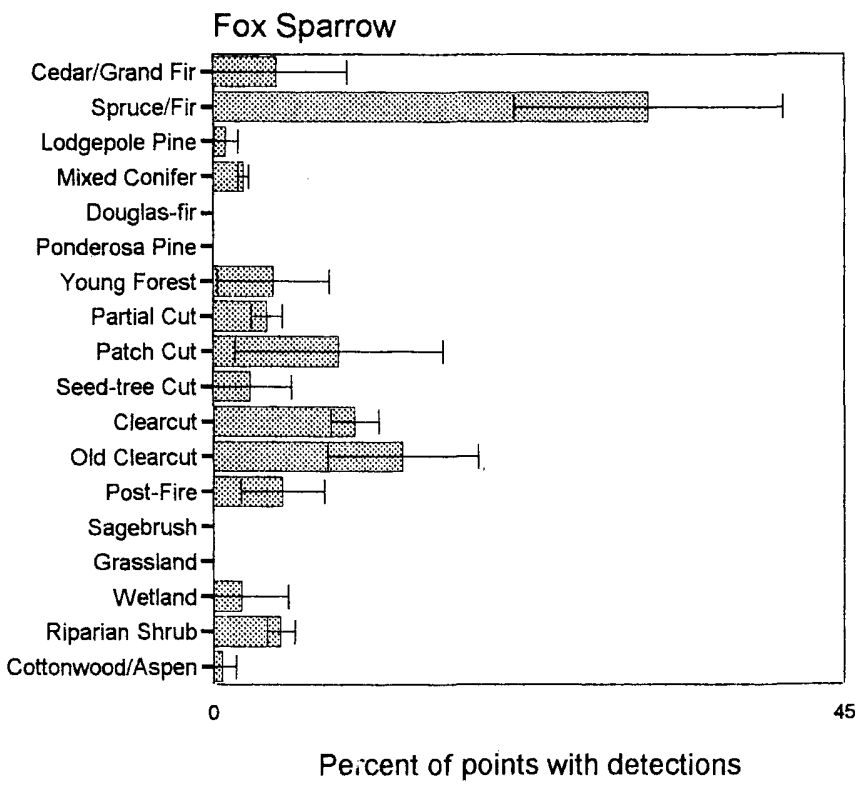

Figure 88

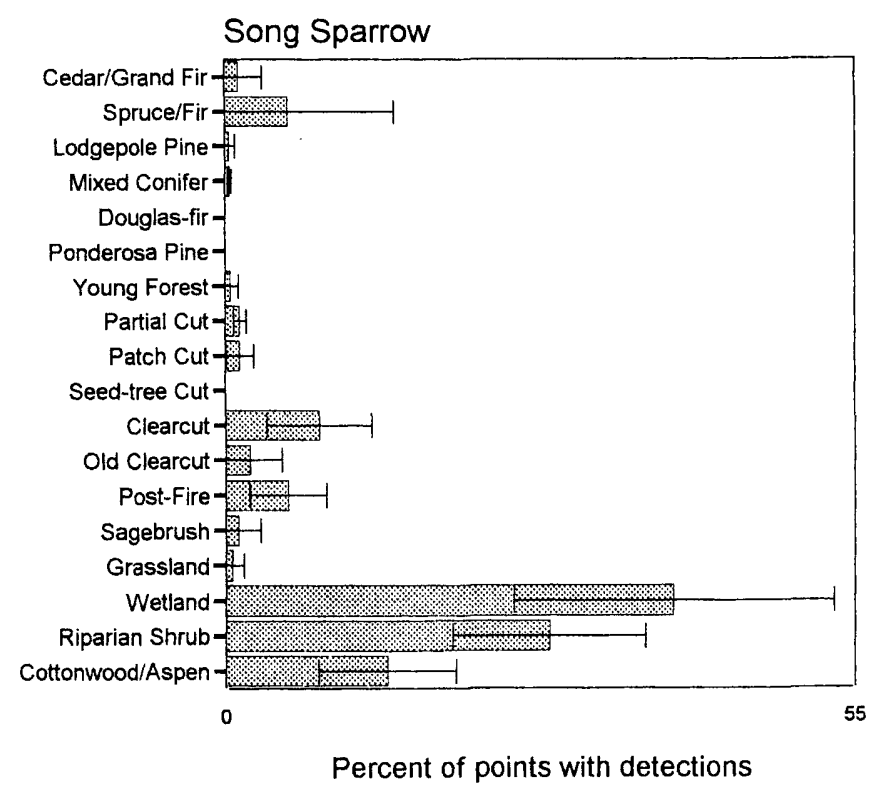


Lincoln's Sparrows (fig. 89) were detected on 94 points in all 3 years combined, primarily in higher elevation, Riparian Shrub and Wetland environments, including the riparian draws within some early postfire forests and harvested stands. Because the species is restricted to riparian conditions, any negative effects of streamside riparian practices would be of considerable consequence to the maintenance of a viable population.
White-crowned Sparrows (fig. 90) were detected on 38,43 , and 53 of the points in the 3 years, especially woody draws in Sagebrush and Post-Fire cover types. In aspen and willow cover types, this species seems to be negatively affected by grazing activity, and is nearly five times less abundant, on average, in grazed than ungrazed conditions (Saab and others 1995).
Figure 89
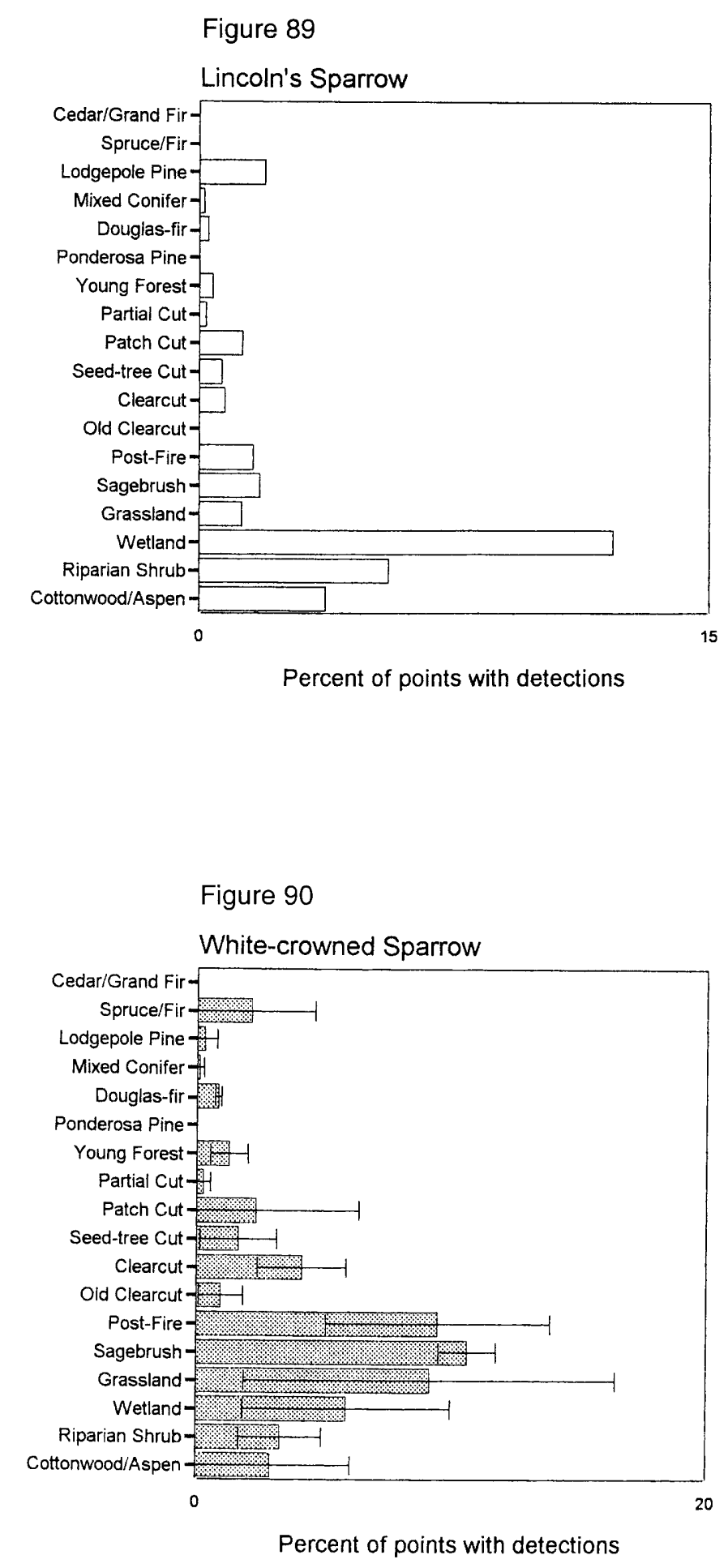
Dark-eyed Juncos (fig. 91) were detected on 1295, 1100 , and 1082 of the points in the 3 years. They occurred in a wide range of forest cover types. They nest on the ground, often beneath downed logs, so it is not surprising that they are three times more likely to occur on points with an abundance of dead and down (57.9 percent occurrence) than on points without any dead and down nearby (18.8 percent occurrence). There would not seem to be much to worry about with a species as widespread and common as this one. Nonetheless, maintaining the dead-and-down component in harvested areas may be needed to maintain healthy populations of this species. This species is so ubiquitous, both spatially and temporally, that no significant biases are expected in the data.
Figure 91

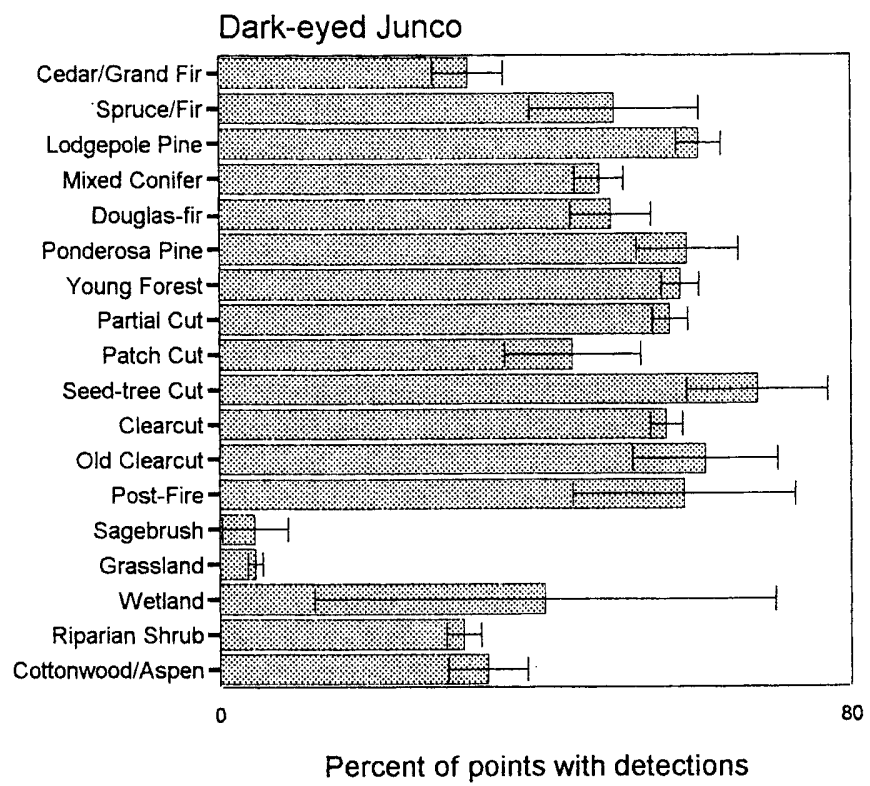

Figure 92

Black-headed Grosbeaks (fig. 92) were detected on 73,55 , and 69 of the points in the 3 years, in riparian and early successional areas. They were relatively abundant in variously cut forest types, and may be benefitting from various cutting practices. Alternatively, cut forests may be acting as "ecological traps" by containing the appropriate superficial characteristics but being otherwise unsuitable. Research is needed to resolve this issue. Because of their abundance in riparian bottomlands, another issue is whether they may be affected negatively by land use practices therein, especially livestock grazing. In aspen, cottonwood, and willow cover types, this species is uniformly negatively affected by grazing activity (Saab and others 1995).

The Black-headed Grosbeak is not restricted to west of the Continental Divide (Montana Bird Distribution Committee 1996), but we had only two detections on the eastside. Restriction of data to westside points did increase the detection probabilities in riparian cover types, so that Cottonwood/Aspen became the most frequented cover type, as expected for this species. However, all of the standard deviations were still large, and there were a total of only nine detections in cottonwood stands ( 11 percent) and only one in aspen. A decline in detectability of this species as the season progressed resulted in 80 percent of the detections occurring by June 25 . Restricting the data to this period increased its prominence in postdisturbance cover types (Clearcut and Post-Fire), but did not otherwise change the habitat distribution pattern.
Black-headed Grosbeak

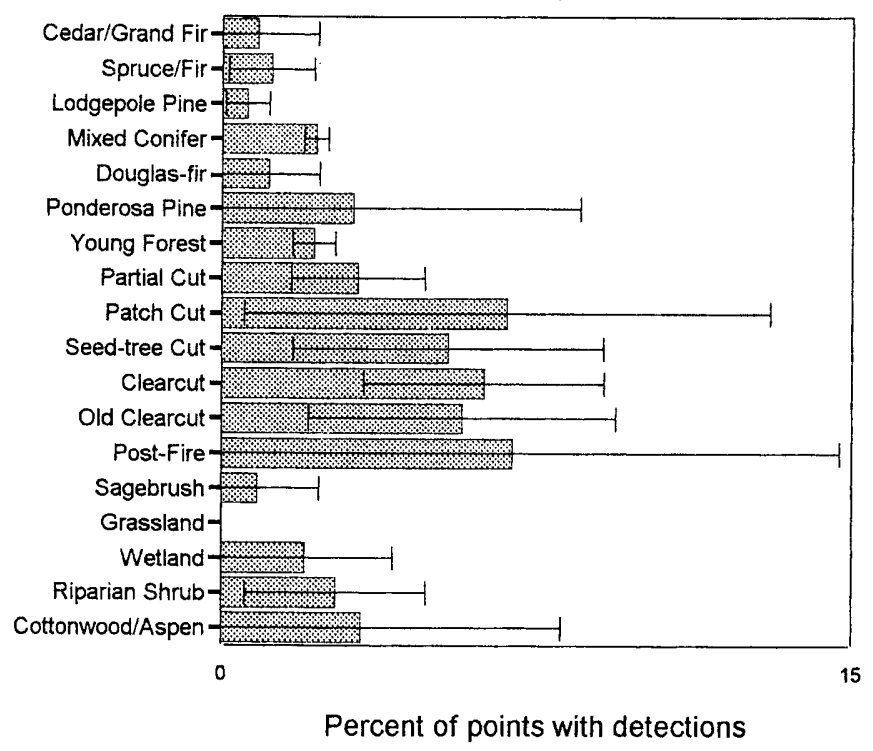


Lazuli Buntings (fig. 93) were detected on 57, 51, and 46 of the points in the 3 years. They are associated primarily with shrubfields (especially in postfire situations, where Hutto [1995] showed them to be at least as frequent as in the Clearcuts sampled here), and shrubby vegetation in riparian areas. Through fire suppression efforts and silvicultural treatments that shorten the shrub stages following disturbance, we may have decreased the amount of early successional habitat for this species, although the data suggest this is well compensated by shrubby Clearcuts, if the species is doing well in such cover types. Data from local studies (E. Greene, unpubl. data) suggest that Lazuli Buntings are susceptible to cowbird parasitism and are heavily parasitized in areas used by cowbirds. Thus, we need more information on parasitism rates under different management regimes (especially cattle grazing around riparian areas). An increase in detectability of this species as the season progressed resulted in 80 percent of the detections occurring from June 9 onward. However, restricting the data to this period did not change the habitat distribution pattern.

Red-winged Blackbirds (fig. 94) were detected on 35 points in all 3 years combined, nearly exclusively in marshlands (and in agricultural lands, as recorded in additional surveys not reported here). The main concern for this species is probably loss of habitat per se through draining of wetlands and conversion to agricultural uses. In addition, six of seven studies of grazing effects on western birds showed this species to be negatively affected by grazing (Saab and others 1995).
Figure 93

Lazuli Bunting

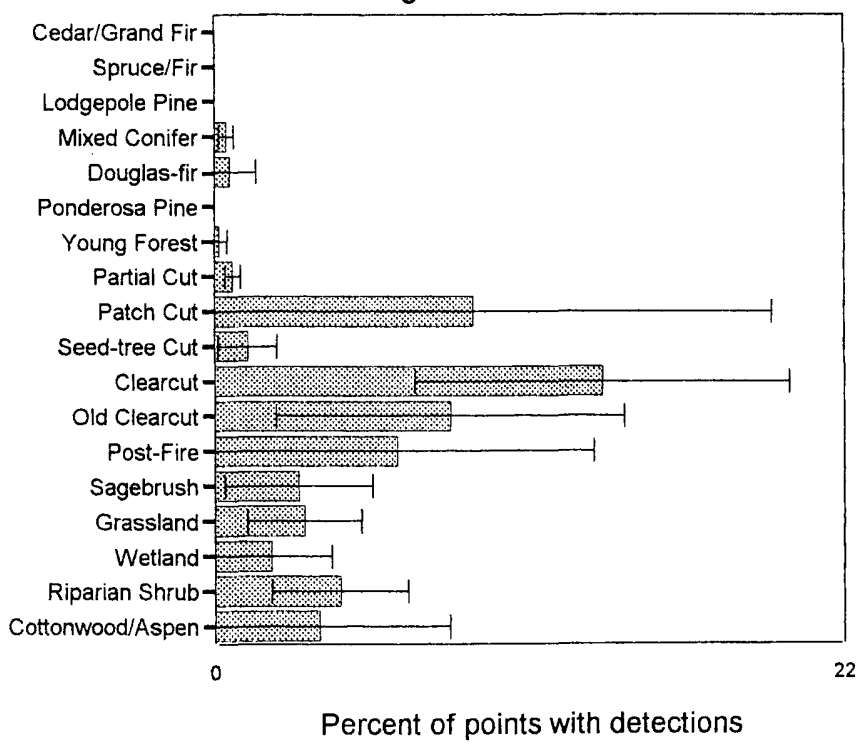

Figure 94

Red-winged Blackbird

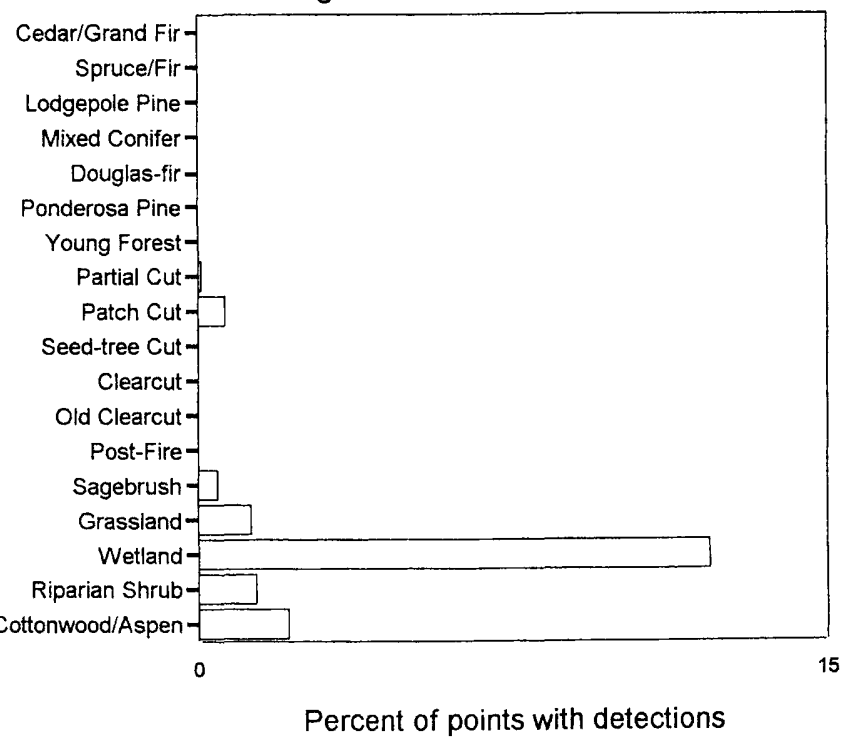


Western Meadowlarks (fig. 95) were detected on 137,65 , and 42 of the points in the 3 years, nearly exclusively in Grasslands and Sagebrush (and in agricultural lands, as recorded in additional surveys not reported here). This species declined in detectability strongly through the season, with 80 percent of the detections occurring by June 12 . However, because this species was so strongly restricted to Grassland and Sagebrush, no subset of the data would change this pattern. In terms of population response to grazing, this species has been shown to be negatively affected by grazing in many studies, but the effect is generally weak or inconclusive (Saab and others 1995). We need information on the nesting success (not just population density) of this species under alternative management regimes in sagebrush and grassland cover types.

Brown-headed Cowbirds (fig. 96) were detected on 190,120 , and 85 of the points in the 3 years, in a wide variety of cover types. They were largely absent from dense, old growth, and high-elevation forests. Cowbirds were most abundant in open conifer forest (Ponderosa Pine and partially logged sites) as well as Grassland and riparian cover types (and in agricultural lands, as recorded in additional surveys not reported here). A decline in detectability of this species as the season progressed resulted in 80 percent of the detections occurring by June 26 . However, restricting the data to this period did not change the habitat distribution pattern.

Because cowbirds were fairly restricted to areas east of the Continental Divide until their expansion with the cattle industry, numerous western songbird species that had not evolved in the presence of cowbirds are now experiencing parasitism for the first time and at rates that may be too great for them to counter in an adaptive sense. The phenomenon is interesting but one that does not bode well for species that occur in the presence of high cowbird densities. In a multiple regression analysis of factors influencing cowbird distribution in the Northern Rocky Mountains (Young and Hutto 1999), models were dominated by landscape rather than vegetation variables. In fact, distance to agricultural lands was the strongest predictor of cowbird presence. Cowbirds were so strongly associated with the proximity of agricultural areas that many areas of the forested mountains are probably still safe from parasitism pressure. Cowbirds may be a textbook example of the importance of landscape context in the distribution of a bird species. We need additional studies to determine how cowbird densities and parasitism rates are related to alternative landuse practices and to various landscape configurations.
Figure 95

Western Meadowlark

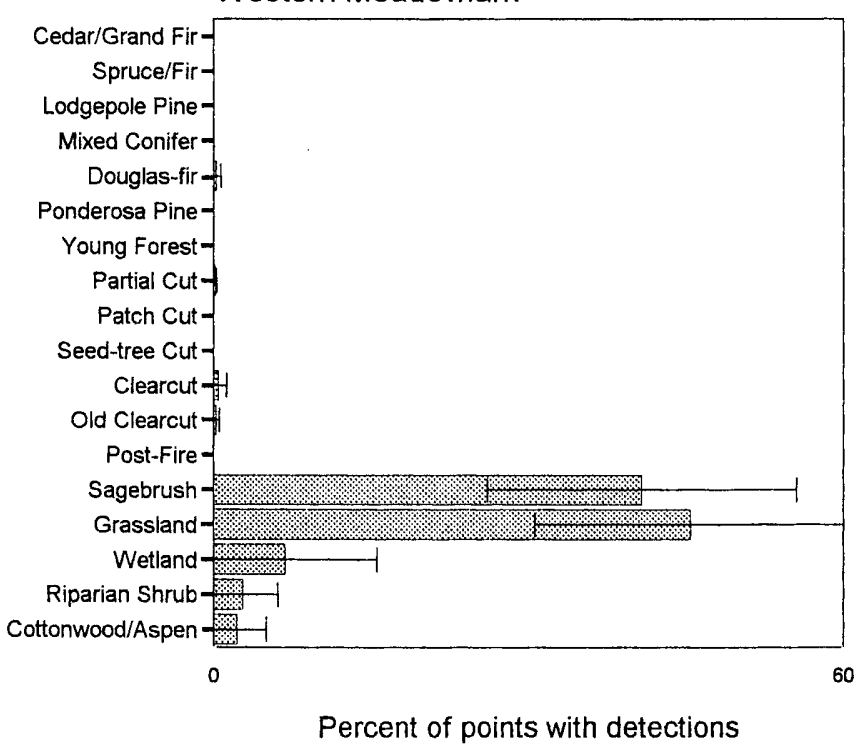

Figure 96

Brown-headed Cowbird

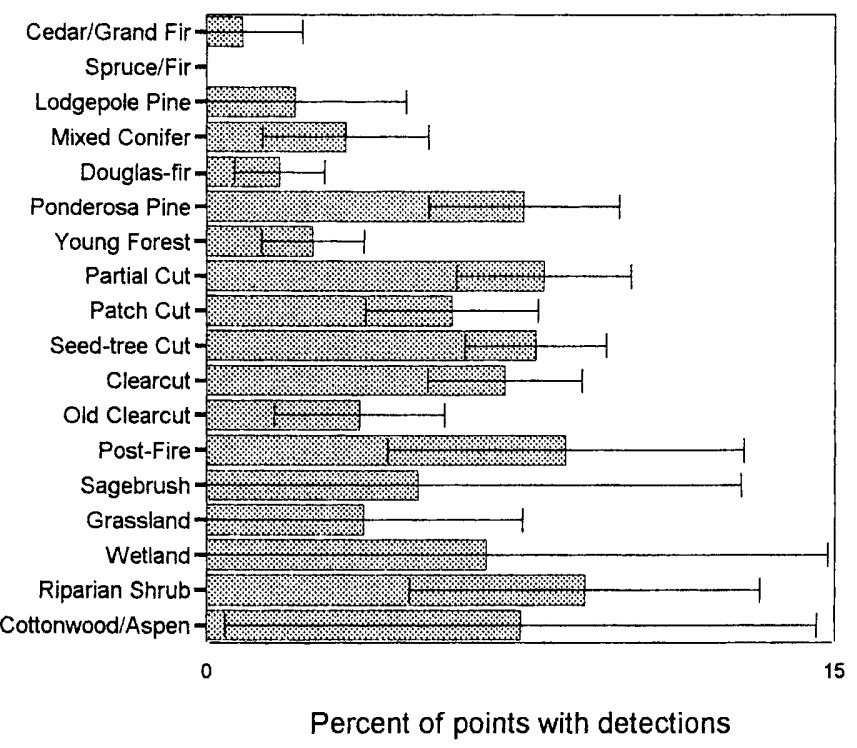


Pine Grosbeaks (fig. 97) were detected on 49 points in all 3 years combined, most commonly in the higher elevation Spruce/Fir forests. This is another species that appears to be more abundant in relatively uncut than in harvested forest types. Some studies have indicated a negative effect of logging (Hejl and others 1995), but more information is needed. The maintenance of viable populations of this species probably necessitates the maintenance of tracts of relatively uncut, high elevation conifer forests.
Figure 97

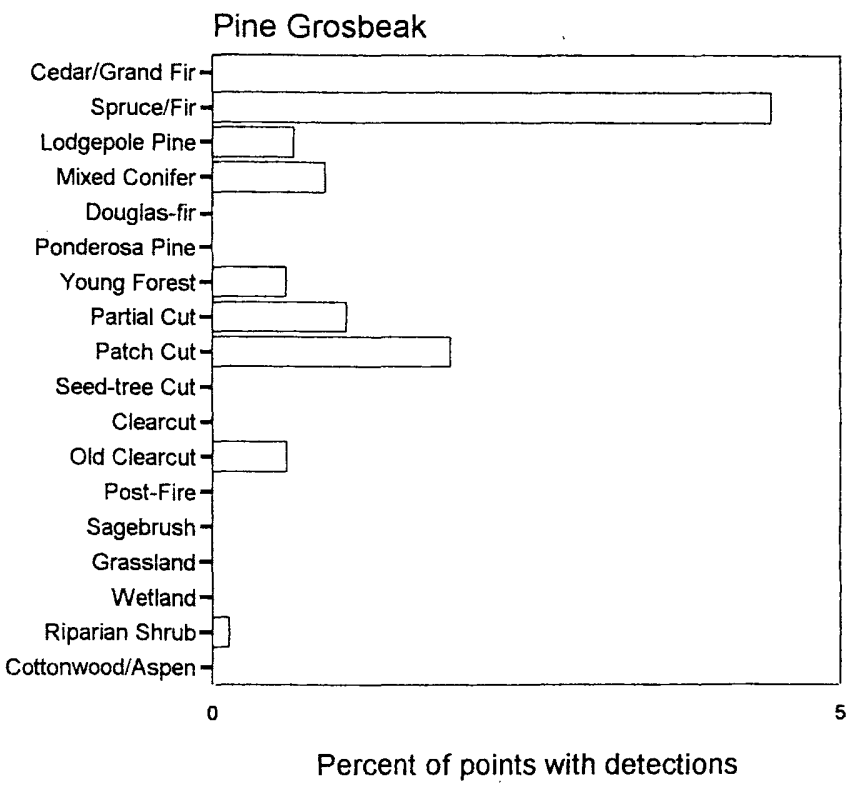

Figure 98

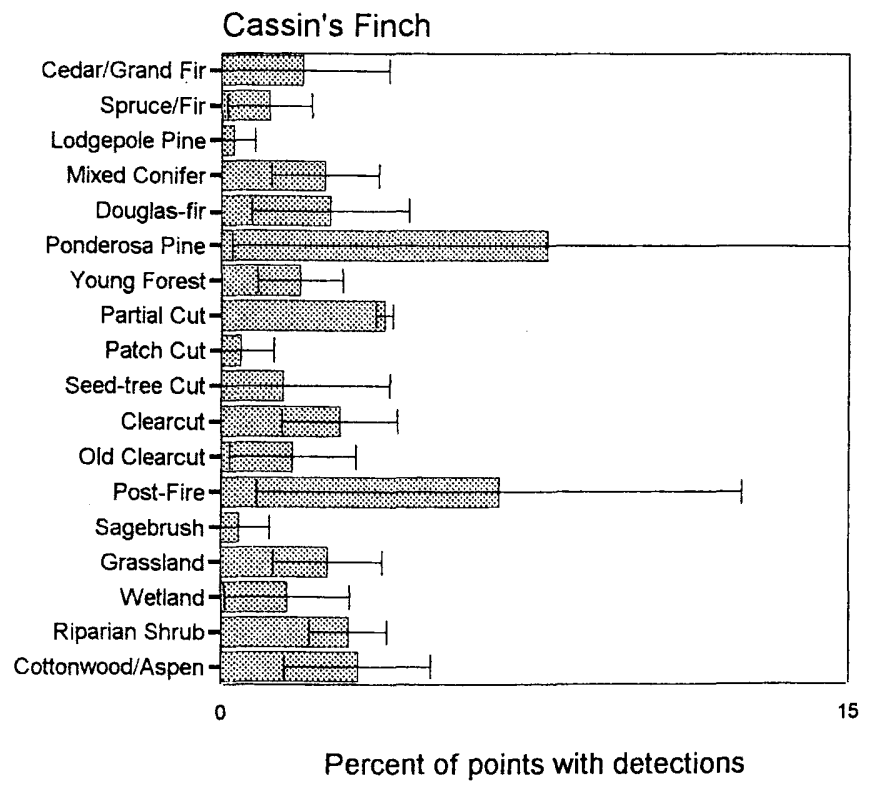


Red Crossbills (fig. 99) were detected on 75, 59, and 162 of the points in the 3 years, and were broadly distributed across most of the conifer forest types. No special management considerations are suggested by the data, but we should point out that this is an extremely mobile and widespread bird species that can be detected in most conifer forest types. Its reliance on productive cone crops has implications for the effects of logging and loss of old growth (Benkman 1993). Thus, managers will need to pay careful attention to its nesting and feeding biology (see, for example, Benkman 1993) to better determine the characteristics within conifer forests that best meet its needs.

Pine Siskins (fig. 100) were detected on 224, 332, and 594 of the points in the 3 years, and were more broadly distributed across cover types than most any other songbird species in the region. The widespread distribution of this species suggests that there is little of current management concern here, but there are data from western Montana (Hunt 1989) that show a positive correlation between siskin density and the severity of a spruce budworm outbreak. Thus, their distribution and abundance may depend to some extent on the locations and extents of such outbreaks. Because the species is so vocal and wide-ranging, it may be impossible to determine its habitat needs from habitat distribution data alone.
Figure 99

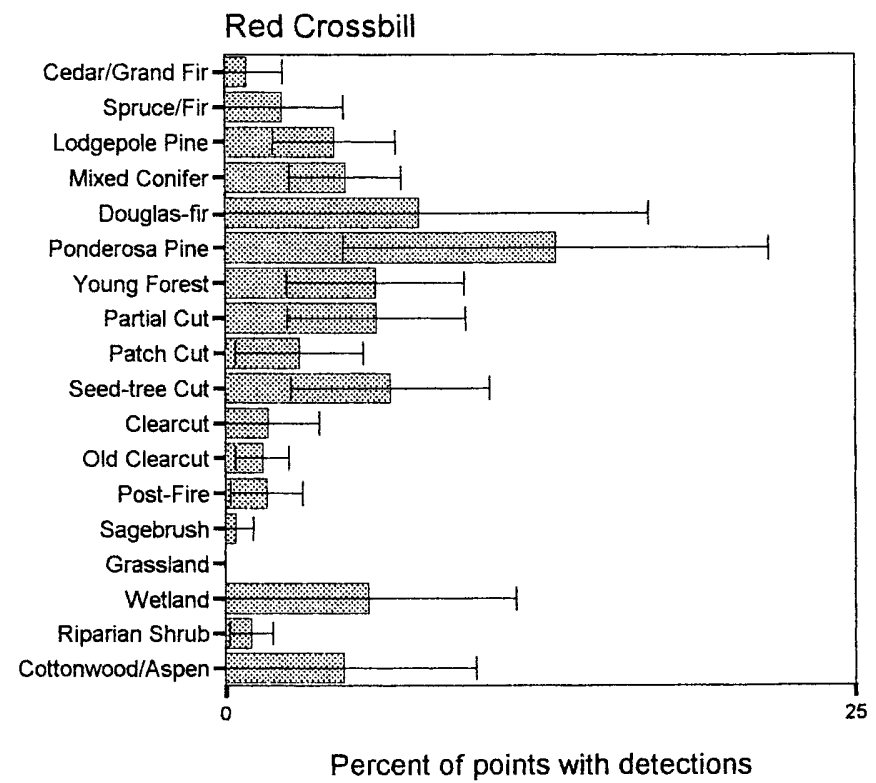

Figure 100

Pine Siskin

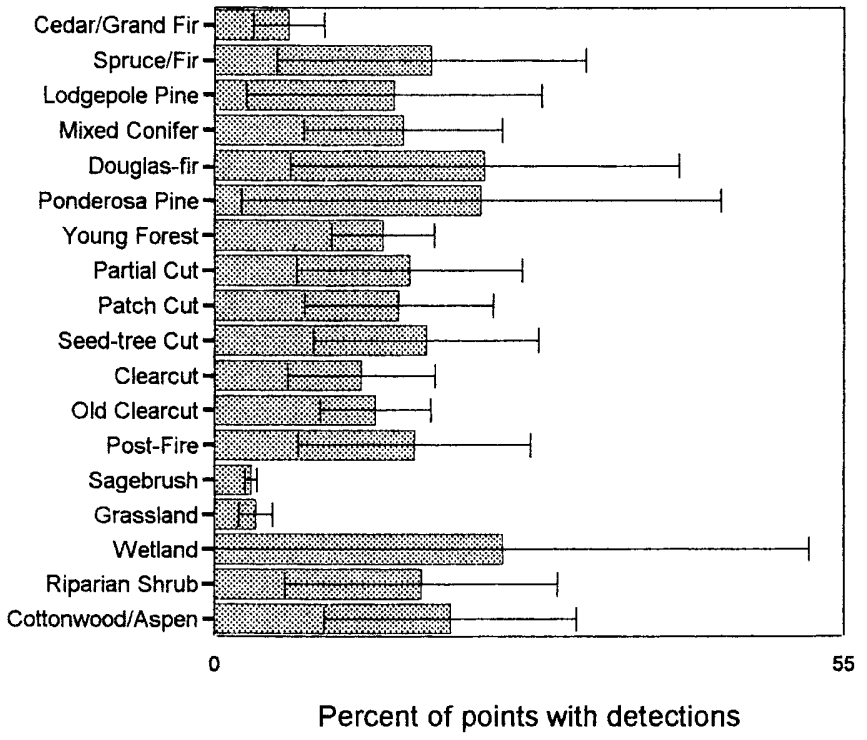


Evening Grosbeaks (fig. 101) were detected on 39, 36 , and 49 of the points in the 3 years, and were fairly uniformly distributed across all the conifer forest types. No management issues of special concern are suggested by the data, although clearcut logging has also been shown elsewhere to negatively affect this species (Hejl and others 1995). The high variances around the mean detections may reflect true variability in abundance from year to year in response to variation in food (especially spruce budworm) availability. It is of special management interest that this and other irruptive, social fringillid species seem to feed heavily on spruce budworm (Takekawa and Garton 1984).

Only nine of the detections occurred east of the Continental Divide, although this does not reflect a range restriction (Montana Bird Distribution Committee 1996). Little change was observed when data were restricted to the westside. A decline in detectability of this species as the season progressed resulted in 80 percent of the detections occurring by June 24. When the data were restricted to this period, Ponderosa Pine and Mixed Conifer increased in prominence, with other minor differences, but the variability of this species makes conclusions questionable.
Figure 101

Evening Grosbeak

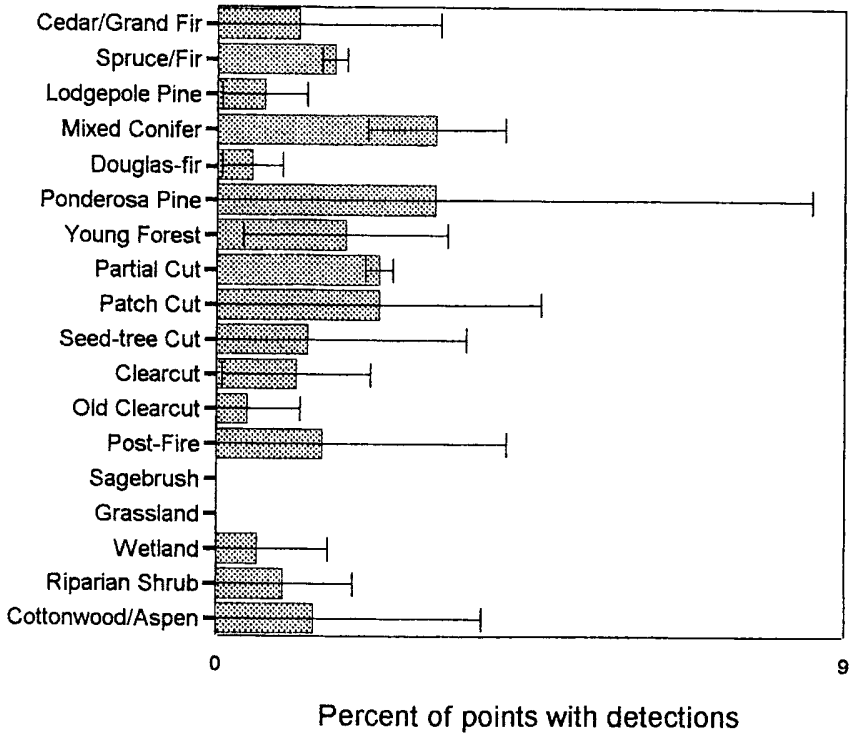




\section{Discussion}

If the goal of our public land management agencies is to maintain ecosystem integrity in the face of many demands on the land, then knowledge of biological consequences of various actions will aid in land use decisions. A landbird monitoring program such as this, which is large enough and ecologically broad enough, can help us predict and monitor the effects of management activities on bird species for almost all the major vegetation types in a region. Results from our initial short-term effort clearly demonstrate some limits within which any agency aspiring to maintain ecological integrity must work.

Specifically, some landbird species are relatively restricted in their habitat distribution to only one or two naturally occurring cover types that are themselves restricted in spatial extent, or at least less extensive than they were in the preindustrial past. The loss of any one of these cover types will mean the loss of those bird species that are relatively restricted to it. Thus, managers need to maintain each of those cover types (defined at least as finely as we have defined them herein) on the broader landscape, although it is unclear how much of each needs to be retained to maintain viable populations of any given species. Even if we are not about to lose a given cover type from the broader landscape, land use practices within and surrounding that type may have important implications, especially for species restricted to that cover type. We provide specific examples and implications of relatively restricted distributions. Species that best illustrate a given distribution pattern are highlighted in bold lettering.

\section{Post-Fire, Standing-Dead Forests}

Examples of inhabitants of these forests are Threetoed Woodpecker and Mountain Bluebird. The Blackbacked Woodpecker may be the species most restricted to this cover type (Hutto 1995), although we did not have sufficient data to demonstrate that here. Even widespread species such as Hairy Woodpecker and American Robin tend to be most abundant in burned forests (Hutto 1995). Salvage logging may have a negative effect on species that are either relatively restricted to, or are most abundant in, early postfire conditions because those bird species depend to a great extent on standing dead trees in burned forests for feeding or nesting (Caton 1996, Hitchcox 1996, Hutto 1995, Saab and Dudley 1998). The presence of such narrowly distributed habitat specialists leaves little doubt that clearcutting associated with a large portion of postfire salvage logging is in direct conflict with the needs of some of these bird species.

\section{Relatively Uncut Forests}

Examples of inhabitants of these forests are Brown Creeper, Winter Wren, Golden-crowned Kinglet, Hermit Thrush, Varied Thrush, and Townsend's Warbler. Based on observed differences in the probabilities of occurrence between the cut and uncut forest types, the cutting (even light thinning) of dense, older forests (especially Cedar/Grand Fir) will have negative effects on several species that are relatively restricted to those conditions. In fact, some of these species (for example, Brown Creeper and Winter Wren) require not only relatively uncut, but relatively old forests as well. To assure the maintenance of their populations, we probably need to maintain relatively large patches of uncut forest types on the landscape. These conclusions are similar to those drawn after a comprehensive literature survey of the effects of timber harvesting on Rocky Mountain birds (Hutto and others 1993, Hejl and others 1995).

\section{Harvested Forest Types}

Although no bird species is entirely restricted to one or more of the harvested forest cover types, many show considerably higher probabilities of detection in cut than in uncut forests. Examples are American Kestrel, Calliope Hummingbird, Rufous Hummingbird, Williamson's Sapsucker, Northern Flicker, Olive-sided Flycatcher, Dusky Flycatcher, Steller's Jay, Cassin's Vireo, Warbling Vireo, Orange-crowned Warbler, MacGillivray's Warbler, and Black-headed Grosbeak. One potential management issue is related to the fact that harvested forests are "unnatural" in that their structure consists of combinations of elements (for example, widely, or evenly spaced live trees) that simply do not exist in natural successional seres. The problem is that these unnatural cover types may elicit settling responses by species that are "programmed" to respond to superficially similar, but fundamentally different, early successional forest types. In turn, these unnatural forest types may act as "ecological traps," where species are attracted to areas in which suitability (in terms of reproductive success or adult survival or both) is poor because food resources, predation, or parasitism rates are unnaturally high. Although demographic "source" and "sink" areas (as defined by Pulliam 1988) may occur naturally, sink areas are not synonymous with ecological traps. The only time an organism can be "trapped" (differentially attracted to an area within which suitability is poor) is when a system has been so artificially altered that the organism's success depends upon altering its usual settling response.

Because no forest bird species is entirely restricted to harvested conditions, there will always be populations 
in naturally occurring unharvested forest, which may serve as refuges. Moreover, if our abundance data accurately reflect suitability of cover types, conditions for many forest bird species may actually have improved through timber harvesting activities. We need information on survival and reproductive success of birds in harvested forests to determine whether relative abundance is a good reflection of relative suitability or not.

\section{Marshes}

Examples of inhabitants of marshes are Common Snipe, Common Yellowthroat, Lincoln's Sparrow, and Red-winged Blackbird. The draining and conversion of wetlands will have negative effects on species restricted to those conditions. Because our methods were not well designed to capture patchily distributed marsh lands, we did not detect enough of several additional landbird species that are known to fall into this category of restricted distribution (for example, Virginia Rail [Rallus limicola], Sora, Marsh Wren, Yellow-headed Blackbird).

\section{Riparian Vegetation}

Numerous landbird species are relatively restricted to the shrubs or deciduous trees associated with riparian environments. Our data did not allow us to differentiate well between the species that prefer cottonwood bottomlands or upland riparian shrub communities, but many species are relatively restricted to one or both of these types (for example, Ruffed Grouse, Western Wood-Pewee, Willow Flycatcher, Cordilleran Flycatcher, Red-eyed Vireo, Cedar Waxwing, Yellow Warbler, American Redstart, Northern Waterthrush, Song Sparrow). This fact takes on special meaning when we consider that riparian cover types make up less than 0.5 percent of all land area in the Northern Region, and that this cover type (especially the bottomlands) incurs a disproportionate amount of human activity (for example, home building, recreation, and livestock grazing) and cowbird parasitism. Much of this land base is private, making publicly owned land of this type much more important as potential refuges for wildlife that might be sensitive to human activities. We currently lack, but desperately need, information on cowbird parasitism rates in relation to the presence of livestock in riparian bottomlands, and we need information on the effects of vegetation alteration and livestock presence on nesting success of riparian bottomland birds. Additional species that are restricted to riparian bottomlands, but for which we obtained insufficient data to develop models, include the Belted Kingfisher, Bank Swallow, Least Flycatcher, Veery, Gray Catbird, and American Goldfinch. Species restricted to upland riparian streamside vegetation may be especially sensitive to so-called "best management practices," whose effects on a wide variety of riparian-dependent terrestrial wildlife species have never been evaluated. The American Dipper is perhaps the most dramatic example of a landbird species that is restricted to upland riparian (fast-moving stream) conditions, but we obtained too few data on this bird to include in a model.

\section{Grassland, Sagebrush, or Both}

Examples of species inhabiting these areas are Horned Lark, Brewer's Sparrow, Vesper Sparrow, Grasshopper Sparrow, and Western Meadowlark. If we couple the fact that many species are restricted to grassland, sagebrush, or both, with the fact that many of the same species are declining nationwide, the management of those lands becomes a pressing issue. Livestock grazing is a common land-use activity on grassland and shrubsteppe environments and may be incompatible with the needs of some of these bird species (Saab and others 1995). In addition, many species in eastern Montana and the Little Missouri National Grasslands of North Dakota, (for example, Sprague's Pipit [Anthus spragueii], Baird's Sparrow [Ammodramus bairdii], and Chestnut-collared Longspur [Calcarius ornatus]) are entirely restricted to grassland but were not detected in the data from the western portion of the region reported here. Data from the Little Missouri National Grasslands will be reported elsewhere.

\section{Conclusions}

Many patterns of restricted habitat use were already common knowledge (for example, Grasshopper Sparrow is restricted to grasslands, or Brewer's Sparrow is restricted to sagebrush), but other patterns of relatively restricted distribution were probably not as evident prior to this work (for example, Brown Creeper to relatively uncut cedar-hemlock forests). Prior to this survey, it was also common knowledge that many bird species were widely distributed across cover types, but we had no knowledge of the relative abundance of these bird species among cover types, especially harvested forest types. It is now evident that Orange-crowned Warbler and Cassin's Vireo, for example, occur not only broadly across forest types, but most commonly in harvested forest types, and that Williamson's Sapsucker is even relatively restricted to such types.

Although we gathered data for 3 years in the monitoring program, we suspect a well designed program could quite easily gather data from well-defined cover types within a single-season. The detail and regionspecific nature of this information can be matched by no other database in existence, and the information should prove useful in modeling probabilities of occurrence in planning areas that are projected to consist of alternative proportions of various cover types. 


\section{References}

American Ornithologists' Union. 1998. Check-list of North American birds. 7th edition. Washington, DC: The American Ornithologists' Union.

Benkman, C. W. 1993. Logging, conifers, and the conservation of crossbills. Conservation Biology 7: 473-479.

Best, L. B. 1981. Seasonal changes in detection of individual bird species. Studies in Avian Biology 6: 252-261.

Bull, E. L.; Cooper, H. D. 1991. Vaux's Swift nest in hollow trees. Western Birds. 22: 85-91.

Bull, E. L.; Holthausen, R. S. 1993. Habitat use and management of Pileated Woodpeckers in northeastern Oregon. Journal of Wildlife Management 57: 335-345.

Bull, E. L.; Holthausen, R. S.; Henjum, M. G. 1992. Roost trees used by Pileated Woodpeckers in northeastern Oregon. Journal of Wildlife Management 56: 786-793.

Caton, E. L. 1996. Effects of fire and salvage logging on the cavitynesting bird community in northwestern Montana. Missoula, MT: University of Montana. 115 p. Ph.D. Dissertation.

Cyr, A. 1981. Limitation and variability in hearing ability in censusing birds. In: Ralph, C. J.; Scott, J. M., eds. Estimating numbers of terrestrial birds. Studies in Avian Biology 6: 327-333.

Emlen, J. T. 1971. Population densities of birds derived from transect counts. Auk 88: 323-342.

Emlen, J. T.; DeJong, M. J. 1981. The application of song detection threshold distance to census operations. In: Ralph, C. J.; Scott, J. M., eds. Estimating numbers of terrestrial birds. Studies in Avian Biology 6: 346-352.

Galati, B.; Galati, C. B. 1985. Breeding of the Golden-crowned Kinglet in northern Minnesota. Journal of Field Ornithology 56: 28-40.

Grue, C. E.; Balda, R. P.; Johnson, C. D. 1981. Diurnal activity patterns and population estimates of breeding birds within a disturbed and undisturbed desert-scrub community. In: Ralph, C. J.; Scott, J. M., eds. Estimating numbers of terrestrial birds. Studies in Avian Biology 6: 287-291.

Hanowski, J. M.; Niemi, G. J. 1995. A comparison of on- and off-road bird counts: do you need to go off road to count birds accurately? Journal of Field Ornithology 66: 469-483.

Hejl, S. J.; Verner, J.; Balda, R. P. 1988. Weather and bird populations in true fir forests of the Sierra Nevada, California. Condor 90: $561-574$

Hejl, S. J. 1994. Human-induced changes in bird populations in coniferous forests in western North America during the past 100 years. In: Jehl, J. R.; Johnson, N. K., eds. A century of avifaunal change in western North America. Studies in Avian Biology 15: 232-246.

Hejl, S. J.; Paige, L. C. 1994. A preliminary assessment of birds in continuous and fragmented forests of western redcedar/western hemlock in northern Idaho. In: Interior cedar-hemlock-white pine forests: ecology and management: Symposium proceedings; 1993, March 2-4; Spokane, WA. Pullman, WA: Washington State University: 189-197.

Hejl, S. J.; Woods, R. E. 1991. Bird assemblages in old growth and rotation-aged Douglas-fir/ponderosa pine stands in the northern Rocky Mountains: a preliminary assessment. In: Baumgartner, D. M.; Lotan, J. E., eds. Interior Douglas-fir: the species and its management: Symposium proceedings; 1990, February 27March 1; Spokane, WA. Pullman, WA: Washington State University: $93-100$

Hejl, S. J.; Hutto, R. L.; Preston, C. R.; Finch, D. M. 1995. Effects of silvicultural treatments in the Rocky Mountains. In: Martin,T.; Finch, D. M., eds. Ecology and management of neotropical migratory birds. New York: Oxford University Press: 220-244.

Hitchcox, S. M. 1996. Abundance and nesting success of cavitynesting birds in unlogged and salvage-logged burned forest in northwestern Montana. Missoula, MT: University of Montana. 89 p. M.S. Thesis

Hunt, P. D. 1989. The relationships among vegetation structure, western spruce budworm density, and avian community composition. Missoula, MT: University of Montana. 59 p. M.S. Thesis.

Hutto, R. L. 1995. The composition of bird communities following stand-replacement fires in Northern Rocky Mountain (U.S.A.) conifer forests. Conservation Biology 9: 1041-1058.
Hutto, R. L. 1998. Using landbirds as an indicator species group. In: Marzluff, J. M.; Sallabanks, R., eds. Avian Conservation: research and management. Covello, CA: Island Press: 75-92.

Hutto, R. L.; Hejl, S. J.; Kelly, J. F.; Pletschet, S. M. 1995. A comparison of bird detection rates derived from on-road versus off-road point counts in northern Montana. In: Ralph, C. J.; Sauer, J. R.; Droege, S., eds. Monitoring bird populations by point counts. Gen. Tech. Rep. PSW-GTR-149. Albany, CA: U.S. Department of Agriculture, Forest Service, Pacific Southwest Research Station: 103-110.

Hutto, R. L.; Hejl, S. J.; Preston, C. R.; Finch, D. M. 1993. Effects of silvicultural treatments on forest birds in the Rocky Mountains: implications and management recommendations. In: Finch, D. M.; Stangel, P. W., eds. Status and management of neotropical migratory birds. Gen. Tech. Rep. RM-229. Fort Collins, CO: U.S. Department of Agriculture, Forest Service, Rocky Mountain Forest and Range Experiment Station: 386-391.

Hutto, R. L.; Hoffland, J. 1996. USDA Forest Service Northern Region Landbird Monitoring Project: Field Methods. in-house report.

Hutto, R. L.; Pletschet, S. M.; Hendricks, P. 1986. A fixed-radius point count method for nonbreeding and breeding season use. Auk 103: 593-602.

Kavanagh, R.; Recher, H. F. 1983. Effects of observer variability on the census of birds. Corella 7: 93-100.

Keller, C. M. E.; Fuller, M. R. 1995. Comparison of birds detected from roadside and off-road point counts in the Shenandoah National Park. In: Ralph, C. J.; Sauer, J. R.; Droege, S., eds. Monitoring bird populations by point counts. Gen. Tech. Rep. PSW-GTR-149. Albany, CA: U.S. Department of Agriculture, Forest Service, Pacific Southwest Research Station: 111-116.

Mannan, R. W.; Meslow, E. C. 1984. Bird populations and vegetation characteristics in managed and old growth forests, northeastern Oregon. Journal of Wildlife Management 48: 1219-1238.

Manuwal, D. A. 1991. Spring bird communities in the southern Washington Cascade Range. In: Ruggiero, L. F.; Aubry, K. B.; Carey, A. B.; Huff, M. H., eds. Wildlife and vegetation of unmanaged Douglas-fir forests. Gen. Tech. Rep. PNW-GTR-285. Portland, OR: U.S. Department of Agriculture, Forest Service, Pacific Northwest Research Station: 159-174.

McEllin, S. M. 1979. Nest sites and population demographics of White-breasted and Pygmy nuthatches in Colorado. Condor 81: 348-352.

Montana Bird Distribution Committee. 1996. P. D. Skaar's Montana Bird Distribution, Fifth edition. Special Publication No. 3. Helena, MT: Montana Heritage Program. 130 pp.

Morrison, M. L. 1981. The structure of western wood warbler assemblages: analysis of foraging behavior and habitat selection in Oregon. Auk 98: 578-88.

Mosconi, S. L.; Hutto, R. L. 1982. The effect of grazing on the land birds of a western Montana riparian habitat. In: Nelson L.; Peek, J. M., eds. Proceedings of the Wildlife-Livestock Relationships Symposium. Forest, Wildlife and Range Experiment Station, Moscow, ID: University of Idaho: 221-233.

O'Connor, R. J. 1981a. The influence of observer and analyst efficiency in mapping method censuses. In: Ralph, C. J.; Scott, J. M., eds. Estimating numbers of terrestrial birds. Studies in Avian Biology 6: 372-376.

O'Connor, R. J. 1981b. Habitat correlates of bird distribution in British census plots. Studies in Avian Biology 6: 533-537.

O'Connor, R. J.; Hicks, R. K. 1980. The influence of weather conditions on the detection of birds during Common Bird Census fieldwork. Bird Study 27: 137-151.

Paulson, D. 1993. Shorebirds of the Pacific Northwest. Seattle, WA: University of Washington Press.

Peterjohn, B.G.; Sauer, J. R.; Link, W. A. 1996. The 1994 and 1995 summary of the North American Breeding Bird Survey. Bird Populations 3: 48-66.

Pulliam, H. R. 1988. Sources, sinks, and population regulation. American Naturalist 132: 652-661.

Ralph, C. J. 1981. An investigation of the effect of seasonal activity levels on avian censusing. In: Ralph, C. J.; Scott, J. M., eds. Estimating numbers of terrestrial birds. Studies in Avian Biology 6: $265-270$ 
Ralph, C. J.; Droege, S.; Sauer, J. R. 1995. Managing and monitoring birds using point counts: standards and applications. In: Ralph, C. J.; Sauer, J. R.; Droege, S., eds. Monitoring bird populations by point counts. Gen. Tech. Rep. PSW-GTR-149. Albany, CA: U.S. Department of Agriculture, Forest Service, Pacific Southwest Research Station: 161-168.

Ramsey, F. L.; Scott, J. M. 1981. Tests of hearing ability. In: Ralph, C. J.; Scott, J. M., eds. Estimating numbers of terrestrial birds. Studies in Avian Biology 6: 341-345.

Robbins, C. S. 1981a. Effect of time of day on bird activity. In: Ralph, C. J.; Scott, J. M., eds. Estimating numbers of terrestrial birds. Studies in Avian Biology 6: 275-286.

Robbins, C. S. 1981b. Bird activity levels related to weather. In: Ralph, C. J.; Scott, J. M., eds. Estimating numbers of terrestrial birds. Studies in Avian Biology 6: 301-310.

Rodenhouse, N. L.; Best, L. B. 1983. Breeding ecology of Vesper Sparrows in corn and soybean fields. American Midland Naturalist 110: $265-275$.

Saab, V. A.; Dudley, J. G. 1998. Responses of cavity-nesting birds to stand-replacement fire and salvage logging in ponderosa pine/ Douglas-fir forests of southwestern Idaho. Research Paper. RMRS-RP-11. Ogden, UT: U.S. Department of Agriculture, Forest Service, Rocky Mountain Research Station

Saab, V. A.; Bock, C. E.; Rich, T. D.; Dobkin, D. S. 1995. Livestock grazing effects in western North America. In: Martin,T.; Finch, D. M., eds. Ecology and management of neotropical migratory birds. New York: Oxford University Press: 311-353.

Sharp, B. E. 1996. Avian population trends in the Pacific Northwest. Bird Populations 3: 26-45

Shields, W. M. 1977. The effect of time of day on avian census results. Auk 94: 380-383.

Smith, P. G. R. 1984. Observer and annual variation in winter population studies. Wilson Bulletin 96: 561-574.
Stewart, R. M.; Henderson, R. P.; Darling, K. 1977. Breeding ecology of the Wilson's Warbler in the Sierra Nevada, California. Living Bird 16: 83-102.

Takekawa, J. Y.; Garton, E. O. 1984. How much is an Evening Grosbeak worth? Journal of Forestry 82: 426-428.

Tewksbury, J. J.; Hejl, S. J.; Martin, T. E. 1998. Breeding productivity does not decline with increasing fragmentation in a western landscape. Ecology 79(8): 2890-2903.

Tobalske, B. W. 1992. Evaluating habitat suitability using relative abundance and fledging success of Red-naped Sapsuckers. Condor 94: 550-553.

Tobalske, B. W.; Hutto, R. L.; Shearer, R. C. 1990. The effects of timber harvesting on the reproductive success of Red-naped Sapsuckers (Sphyrapicus nuchalis). The Northwest Environmental Journal 6: 398-399.

Tomback, D. F. 1998. Clark's Nutcracker (Nucifraga columbiana). In: Poole, A.; Gill, F., eds. The Birds of North America, No. 331. Philadelphia, PA: The Academy of Natural Sciences, and Washington, DC: The American Ornithologists' Union.

Verner, J. 1985. Assessment of counting techniques. Current Ornithology 2: 247-302.

Wiens, J. A.; Rotenberry, J. T.; Van Horne, B. 1987. Habitat occupancy patterns of North American shrubsteppe birds: the effects of spatial scale. Oikos 48: 132-147.

Young, J. S.; Hutto, R. L. 1999. Habitat and landscape factors affecting cowbird distribution in the Northern Rockies. Studies in Avian Biology 18: 41-51.

Zwickel, F. C. 1992. Blue Grouse (Dendragapus obscurus). In: Poole, A.; Stettenheim, P.; Gill, F., eds. The Birds of North America, No. 15. Philadelphia, PA: The Academy of Natural Sciences, and Washington, DC: The American Ornithologists' Union. 




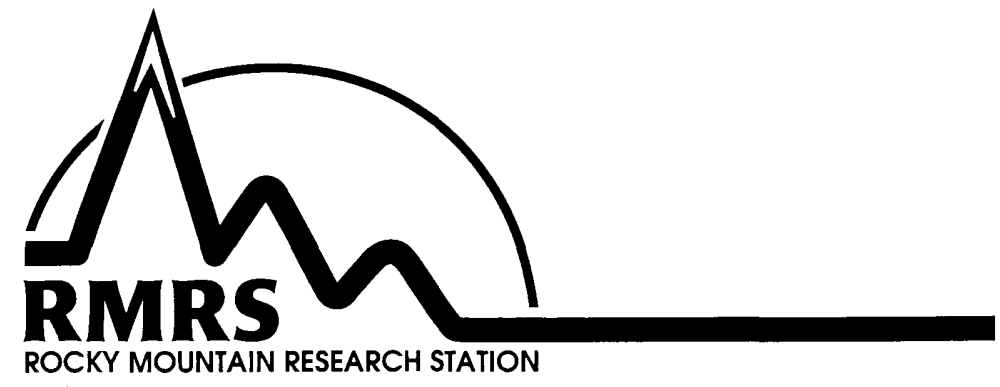

The Rocky Mountain Research Station develops scientific information and technology to improve management, protection, and use of the forests and rangelands. Research is designed to meet the needs of National Forest managers, Federal and State agencies, public and private organizations, academic institutions, industry, and individuals.

Studies accelerate solutions to problems involving ecosystems, range, forests, water, recreation, fire, resource inventory, land reclamation, community sustainability, forest engineering technology, multiple use economics, wildlife and fish habitat, and forest insects and diseases. Studies are conducted cooperatively, and applications may be found worldwide.

\section{Research Locations}

Flagstaff, Arizona

Fort Collins, Colorado*

Boise, Idaho

Moscow, Idaho

Bozeman, Montana

Missoula, Montana

Lincoln, Nebraska
Reno, Nevada

Albuquerque, New Mexico

Rapid City, South Dakota

Logan, Utah

Ogden, Utah

Provo, Utah

Laramie, Wyoming

*Station Headquarters, 240 West Prospect Road, Fort Collins, CO 80526

The U.S. Department of Agriculture (USDA) prohibits discrimination in all its programs and activities on the basis of race, color, national origin, gender, religion, age, disability, political beliefs, sexual orientation, and marital or familial status. (Not all prohibited bases apply to all programs.) Persons with disabilities who require alternative means for communication of program information (Braille, large print, audiotape, etc.) should contact USDA's TARGET Center at 202-720-2600 (voice and TDD).

To file a complaint of discrimination, write USDA, Director, Office of Civil Rights, Room 326-W, Whitten Building, 14th and Independence Avenue, SW, Washington, DC 20250-9410 or call 202-720-5964 (voice or TDD). USDA is an equal opportunity provider and employer.

\footnotetext{
Federal Recycling Program Printed on Recycled Paper
} 